\title{
SOUTH-NORTH TRADE, INTELLECTUAL PROPERTY JURISDICTIONS, AND FREEDOM TO OPERATE IN AGRICULTURAL RESEARCH ON STAPLE CROPS
}

\author{
Eran Binenbaum, Carol Nottenburg, Philip G. Pardey, \\ Brian D. Wright, and Patricia Zambrano
}

Environment and Production Technology Division International Food Policy Research Institute 2033 K Street, N.W.

Washington, D.C. 20006 U.S.A.

Center for the Application of Molecular Biology to International Agriculture, Canberra, Australia

University of California, Berkeley

December 2000 


\begin{abstract}
A biotechnology revolution is proceeding in tandem with international proliferation of intellectual property regimes and rights. Does the intellectual property impede agricultural research conducted in, or of consequence for, developing countries? This question has important spatial dimensions that link the location of production, the pattern of international trade, and the jurisdiction of intellectual property. Our main conclusion is that the current concerns about the freedom to operate in agricultural research oriented towards food crops for the developing world are exaggerated. Rights to intellectual property are confined to the jurisdictions where they are granted, and, presently, many of the intellectual property (IP) rights for biotechnologies potentially useful to developing-country agricultural producers are valid only in developed countries.

IP problems might arise in technologies destined for crops grown in developing countries unencumbered by IP restrictions, if those crops are subsequently exported to countries in which IP is likely to prevail. Thus freedom to trade is also part of the IP story. However, using international production and trade data in the 15 crops critical to food security throughout the developing world, we show that exports from developing to developed countries are generally dwarfed by production and consumption in the developing world, the value of these exports is concentrated in a few crops and a few exporting countries, and the bulk of these exports go to Western Europe. Thus for now, most LDC researchers can focus primarily on domestic IPR in determining their freedom to operate with respect to food staples.

Undue concern with current freedom to operate is diverting attention from the lack of financial and technical support necessary for the effective generation, evaluation, adaptation, and regulation of newly available technologies by public and international nonprofit breeders in LDCs, given the continued inability of private-sector research to fill the gap.
\end{abstract}




\section{CONTENTS}

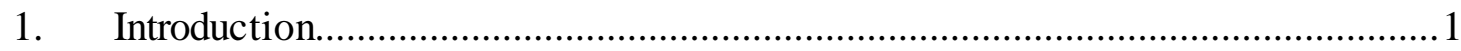

2. Intellectual Property and Agricultural Biotechnologies...........................................

Introduction to Intellectual Property.......................................................................

Forms of Intellectual Property Protection Used in Plant Breeding................................. 7

Infringement and the Freedom to Operate...............................................................12

The International Dimension of Intellectual Property....................................................17

The Freedom to Operate in Agricultural R\&D for Developing Countries.....................23

3. Production and Trade Patterns and the Freedom to Operate...................................29

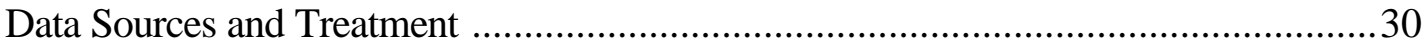

International Production and Trade Totals ................................................................ 32

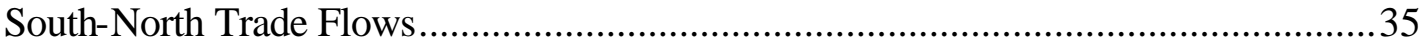

Processed Products, Infringement, and Detectability.................................................42

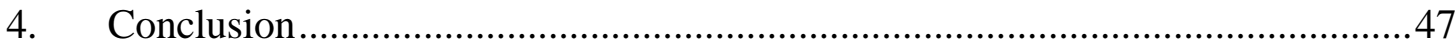

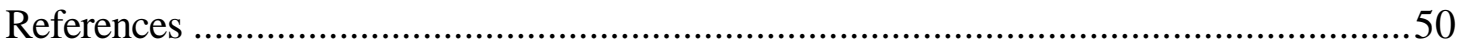




\title{
South-North Trade, Intellectual Property Jurisdictions, and Freedom to Operate in Agricultural Research on Staple Crops
}

\author{
Eran Binenbaum, Carol Nottenburg, Philip G. Pardey, Brian D. Wright, and \\ Patricia Zambrano*
}

\section{INTRODUCTION}

A landmark in the 10,000-year history of agriculture was the Green Revolution—a revolution in agricultural production that took hold in the 1960s giving rise to unprecedented increases in the yields and production of basic food grains worldwide and a commensurate decline in the price of food despite continued population increase. The technologies of improved wheat and rice and other cereals that led to these global gains came from a whole host of sources, including the international agricultural research centers collectively known as the Consultative Group on International Agricultural Research (CGIAR, or CG for short) and national research agencies in developed and developing countries alike. Improved varieties or breeding lines developed in one location spilled over to researchers and farmers working in other locations. Most of the relevant research was paid for and conducted by public agencies,

\footnotetext{
* The authors are listed alphabetically. Philip Pardey is a senior research fellow and Patricia Zambrano a senior research assistant at the International Food Policy Research Institute, Carol Nottenburg is Director of Intellectual Property at the Center for the Application of Molecular Biology to International Agriculture, and Brian Wright is a professor and Eran Binenbaum a Ph.D. student in the Department of Agricultural and Resource Economics, University of California, Berkeley. Stephen Stohs, Bonwoo Koo, and Yuan Liang provided excellent research assistance, and Agapi Somwaru (USDA, ERS) collaborated with us in compiling the trade data. We thank Per Pinstrup-Andersen and Richard Jefferson for their especially helpful comments on earlier drafts. Research for this paper was made possible, in part, by a grant from the Swedish International Development Agency (Sida).
} 
and the technologies and the seeds that embodied them were largely unencumbered by intellectual property (IP) concerns.

The science of agriculture, like the biological and medical sciences more generally, has undergone a sea change in the past few decades. The private sector has become the leader in application of modern methods of genetic transformation which, combined with new information (or bioinformatics) technologies, have opened up entirely new prospects for advances in the function, form, and performance of crops and livestock.

Though the recent achievements in biotechnology of the private sector are widely recognized, many are now concerned about farmers and consumers in the developing world. In agricultural biotechnology, the most visible and controversial field of agricultural research, the portion of the key technology that is protected as intellectual property is highly concentrated in the hands of a small number of large, multinational corporations based in North America and Western Europe. ${ }^{1}$ A similar geographical pattern characterizes global technological innovation in general. A preponderance of the world's technology innovations take place in developed countries of the North, which is inhabited by about 15 percent of the world's population. ${ }^{2}$ Many worry that a lack of capacity to adopt modern technology will isolate a significant portion of the world's population from the benefits of important innovations. According to Sachs (2000, p.81), about "one third of the world's population is technologically disconnected, neither innovating at home nor adopting foreign technologies."

\footnotetext{
${ }^{1}$ See http://www.cambia.org/.

${ }^{2}$ This area includes Japan, Korea, Taiwan, Australia, and Israel, in addition to Western and Northern Europe, the United States, and Canada. This information is based on data from 1997 (Sachs 2000).
} 
Whatever the merits of Sachs' argument for other sectors, it is negated by the history of agricultural development. Over the past four decades, large parts of the putative "technologically isolated" developing world have adopted improved crop varieties and other complementary technologies, often via adaptive innovation complementary to the work of developed-country researchers and the breeding efforts of international agricultural research centers. Moreover, the new technologies are eminently adaptable. Indeed, basic agricultural biotechnology is itself largely generated from research directed at human health, which itself is heavily subsidized in leading developed countries. Although absorptive capacity in LDCs is (and has been) a serious issue, a system of international and national agricultural research centers has brought about benefits from genetic improvements for the vast majority of poor consumers.

Within the worldwide agricultural research community, attention is focusing on another challenge to the continued effectiveness of technology adoption via public agricultural research. The very intellectual property rights that have been associated with the surge of private research in biotechnology now threaten to block access to new developments to public and nonprofit researchers. This problem, a manifestation of the "tragedy of the anticommons" (Heller and Eisenberg 1998), plagues not just agriculture, but the much larger health sciences sector (see, for example, NIH 1998).

In agriculture, a major difficulty is that even in developed countries, the nowdominant private-sector research efforts are concentrated on a small number of crops with high commercial value. In the foreseeable future, the vast number of other crops must rely on public and nonprofit institutions as the principal source of genetic innovations. These institutions in developed countries increasingly find their access to essential 
innovative inputs uncertain, unduly expensive, or, in some reported cases, blocked altogether (Wright 1998, Lindner 1999, Erbisch 2000).

This problem in the North is a source of aggravation and inefficiency, but is no way a serious threat to the well being of consumers because most of their major staples are receiving considerable attention from the private sector. But there is understandable concern in the international research and donor communities that the problems with access to intellectual property experienced in the North constitute a serious threat to the supply of food and fiber to the poor in the South. Much of the world's poor rely for sustenance on crops such as rice, beans, and cassava, which are large in caloric output but largely beyond the focus of the private research sector, and low income elasticities mean that future commercial prospects are modest. The fact that there have been some wellpublicized "donations" of "intellectual property" by major multinational corporations to less-developed countries for certain non-commercial crops has not only highlighted the usefulness of these technologies, but reinforced the impression of a general lack of access to modern technological opportunities for these crops.

The CGIAR and other international and local agricultural research organizations are still supporting and conducting agricultural $R \& D$ geared towards poor farmers and consumers, as they did during the Green Revolution. However, the research budgets of many of these agencies are now dwarfed by those of the major corporations in the field. Major donors have expressed the need for the CGIAR and other international and local agricultural research organizations to negotiate with major corporations to gain access to the toolbox of enabling technologies for use in agricultural research conducted in or for less-developed economies. A survey (Cohen et al. 1998) shows fairly widespread use by CGIAR Centers of "protected" intellectual property, in many cases without formal 
authorization from the patentees. While confirming the extent of international researchers' involvement in the use of biotechnologies, this study also created a sense of urgency regarding the regularization of licensing or other IPR transfer arrangements, at least partly due to confusion regarding the relevant intellectual property rights at the Centers.

In this paper, we argue the concerns in LDCs about current access to essential intellectual property are exaggerated and largely misdirected. International and national agricultural research centers have far greater freedom to operate in agricultural research oriented towards food crops for the developing world than commonly perceived. They are generally able to operate in regions where most modern technologies are unprotected by intellectual property rights. Production in the South of a crop protected only in the North is both legal and moral per se. This point is broached by Barton and Strauss (2000) and is the main force of RAFI (2000). IP is primarily based on national laws. However, if there is significant international trade in agricultural commodities and/or international transfer of the technologies used in their production, identification of valid intellectual property concerns becomes more complex. Thus, the spatial aspects of IP are pivotal to the freedom to operate in agricultural research, and in this paper, we focus on these spatial aspects. $^{3}$

\section{INTELLECTUAL PROPERTY AND AGRICULTURAL BIOTECHNOLOGIES}

Economists, policymakers and even many biotechnologists are largely unfamiliar with the legal aspects and practice of seeking and using rights over IP. To set the stage 
for analysis of policy concerns noted above, we lay out below the basics of IP rights from a legal cum economic perspective, highlighting the primary forms used to protect agricultural biotechnologies.

\section{INTRODUCTION TO INTELLECTUAL PROPERTY}

Intellectual property rights are rights to products of the mind—ideas and the way they are represented—be they artistic, scientific, technological, or economic products, that may be afforded legal protection. Such things as inventions, computer programs, publications, videotapes, and music are intellectual properties. Intellectual properties can be protected by means of copyrights, trademarks, utility patents, plant breeders' rights, and trade secrets. ${ }^{4}$

A utility patent, often referred to simply as a "patent," is awarded for inventions of machines, compositions, and processes. ${ }^{5}$ In agricultural biotechnology, patents may cover, for example, plant transformation methods, vectors, genes, transgenic plants, and the like. For plant breeding materials, protection may be obtained under two significantly different regimes: plant breeders' rights, and, in some jurisdictions, the regular patent system. Plant breeders' rights are an example of so-called sui generis rights: that is, rights designed for a specific field of technology. Plant breeders' rights are harmonized internationally through the UPOV Convention (the International Union for the Protection

\footnotetext{
${ }^{3}$ The trade-related spatial issues discussed here were addressed in a pilot study with less comprehensive data by Binenbaum and Wright (1998).

${ }^{4}$ Other forms of intellectual property protection, such as design patents, are not dealt with here.

${ }^{5}$ The authority for the U.S. patent system is enshrined as article 1, section 8 of the U.S. constitution ratified in 1788. Specifically, section 8, clause 8 of the U.S. Constitution states that Congress shall have power "To promote the Progress of Science and useful Arts, by securing for limited Times to Authors and Inventors the exclusive Right to their respective Writings and Discoveries." Some European countries had patent
} 
of New Plant Varieties—which is currently signed by 46 countries, most recently China, Brazil, Bolivia, Estonia, Kenya, Kyrgyz Republic, Panama, and Slovenia).

IP rights have a number of dimensions that are relevant here, including the requirements for obtaining the rights, the scope of what is protected, the geographical limits to the rights, and the duration of the rights. These dimensions vary according to the type of IP, and the legal and administrative system of each country.

Rationales for granting IP rights include stimulation of new innovations, the provision of incentives for disclosure of new knowledge, ethical considerations of entitlement, and the reduction of transaction costs through clarification of rights. Of these rationales, the first two are perhaps the most important. In the absence of IP protection, new ideas and information that are disclosed are entirely in the public domain. Attempts to benefit commercially from an innovation—or at least recoup the necessary investments—-may fail due to imitation. Knowing this, prospective inventors may underinvest in R\&D. Moreover, where possible, inventors may exploit their inventions in secret. Thus, IP rights are designed to encourage innovation in two ways. First, they provide incentives for the generation of new ideas. Second, they stimulate further advancements through the dissemination of new ideas by way of publication, licensing, or other means.

\section{FORMS OF INTELLECTUAL PROPERTY PROTECTION USED IN PLANT BREEDING}

In plant breeding, patents and plant breeders' rights are the most relevant forms of IP protection. Increasingly, bioinformatics databases are important elements of the currently unfolding biotechnology revolution. Hence, copyrights—often applicable to 
databases and software — are likely to become increasingly important in the biotech sector. They do not, however, affect trade in products embodying the protected information. U.S. state trade secret laws have also been used to protect in-house breeding materials such as the inbred lines of maize used as parents of hybrids. However, trade secret law does not provide protection against independent discovery or reverse engineering of products by their purchasers. Hence, patents afford stronger protection than trade secret law for innovation embodied in most products (Besen and Raskind 1991). Trademarks are used for the protection of certain names of biotechnologies, such as Monsanto's Roundup Ready ${ }^{\mathrm{TM}}$ technology or Aventis’s Liberty ${ }^{\circledR}$ and LibertyLink ${ }^{\circledR}$ technologies. Trademarks protect only names and other symbols denoting products or technologies. They do not protect the technologies themselves. While they do not constitute a major impediment to the freedom to operate, they may be important elements of private commercialization strategies.

As patents are the most critical form of protection for agricultural biotechnology and have the most effect on the freedom to operate, the majority of the following discussion focuses on them. In addition, we deal briefly with plant breeders' rights.

Patents. The patent right is generally considered to be the most powerful in the IP system, enabling the patent holder to exclude all others from making, using, selling or offering to sell the invention in the country that granted the patent right, and importing it into that country ${ }^{6}$ for as long as the patent remains valid. ${ }^{7}$ In order to be patentable, an

the longest continuous patent tradition in the world, granted its first patent in 1449.)

${ }^{6}$ Article 28.1 of Trade Related Aspects of Intellectual Property (TRIPs) Agreement. This and all subsequent references to TRIPs legal articles are taken from GATT (1994).

7 "The term of protection available shall not end before the expiration of a period of twenty years counted from the filing date." Article 33 of TRIPs Agreement. See also Gutterman and Anderson (1997, p.61, n.36). 
invention must satisfy certain criteria of novelty, non-obviousness, and utility or industrial application. In addition to these requirements, the inventor(s) are required to disclose the subject matter to the public in a manner sufficiently clear and complete for the invention to be carried out by a person skilled in the art. ${ }^{8}$ Thus, the granting of a patent is often characterized as being essentially an exchange between the authorities and the patentee: in return for an exclusive right of limited time, the patentee shares detailed information about the invention itself with the public. The policy driving this exchange is to promote advancement of technologies and arts through that disclosure. Some, economists among them, pay more attention to the role of the patent in encouraging innovation, which, if successful, usually furnishes a social purpose even in the absence of disclosure.

Over time, the scope of patent protection has gradually been expanded to include inventions involving living things. In the United States, the first steps in this direction were taken in 1930 with the passage of the Plant Patent Act, which protected asexually reproduced plants, but with distinctness and newness criteria that are interpreted less stringently than the criteria applying to conventional patents or plant breeders' rights. The scope of patentable subject matter was further expanded in 1980 to encompass genetically engineered organisms. In 1980, in the seminal case Diamond v. Chakrabarty, the United States Supreme Court held that such life forms are patentable. ${ }^{9}$ Although the

\footnotetext{
${ }^{8}$ Article 29 of TRIPs Agreement.

${ }^{9} 447$ U.S. 303 (1980). The invention was a bacterium engineered to contain a gene whose product degraded oil and was believed to have significant value for treating oil spills. Notably, the original patent application was filed in 1972 and rejected. It was then appealed to the Patent Office Board of appeals who affirmed the rejection. The next appeal was to the Circuit of Customs and Patent Appeals (CCPA, now the Federal Circuit) who reversed the Board's decision. Finally, the Patent Commissioner sought certification with the Supreme Court who affirmed the CCPA's decision. The patent (U.S. patent no. 4259444) issued on March 31, 1981.
} 
bacterium at issue in Diamond v. Chakrabarty was never commercialized, this ushered in a new era for utility patenting of life forms. Under the 1994 TRIPs (Trade Related Aspects of Intellectual Property) Agreement, patents are available for any invention, ${ }^{10}$ whether products or processes, in all fields of technologies; members are allowed to implement only limited exclusions, including methods of treating humans and plants and animals other than microorganisms.

Under TRIPs, the status of plants as patentable subject matter is unclear and controversial. A member may exclude from patentability "plants and animals other than micro-organisms, and essentially biological processes for the production of plants or animals other than non-biological and microbiological processes."11 Protection of plant varieties, however, must still be provided "either by patents or by an effective sui generis system or by any combination thereof."12 While many member countries of the WTO are still in the process of implementing a protection system for plants, the United States and Europe have led the way in allowing utility patents for plants and particularly for transgenic plants. In 1985, the United States Patent Office Board of Appeals ruled that sexually propagated seeds, plants, and cultured tissue could be protected by utility patents. ${ }^{13}$ More recently, the European Patent Office has held that transgenic methods and plants are not per se unpatentable. ${ }^{14}$

Plant breeders' rights (and plant variety protection certificates). Plant breeders' rights (PBRs), or plant variety protection, is a traditional form of IP protection for plants, which has been codified in most developed countries and increasingly in less-developed

\footnotetext{
${ }^{10}$ Article 27 of TRIPs Agreement.

${ }^{11}$ Article 27(3)(b) of TRIPs Agreement. This article is currently under review by

${ }^{12}$ Ibid

${ }^{13}$ ex parte Hibberd, 227 U.S.P.Q.2d 443 (Pat. Off. Bd. App. 1985).
} members of the WTO. 
countries. While there are differences between countries in implementation of PBRs, generally the laws grant protection to varieties that are novel, distinct, uniform, and stable. Thus, the variety must be clearly distinguishable from previous varieties, be uniform and breed true to type, and must not have been previously sold.

The holders of a plant breeders' right have a legal monopoly over commercialization of their varieties for a prescribed length of time, allowing the recovery of the cost of breeding commercially valuable new plant varieties. ${ }^{15}$ Although the details of protection vary from country to country, in general, the sale, reproduction, import, and export of new varieties of plants are encompassed. Exceptions may be made, however, for both research and use of seed saved by a farmer for replanting. Moreover, in some countries, if a protected variety is used as the basis for genetic engineering, the engineered variety may not be used without permission (e.g., licensing) of the holder of the plant breeders' right. ${ }^{16}$

Contractual and technological tools used to protect proprietary material. In addition to the legal protection afforded by patents, plant breeders' rights, trademarks, and so on, contractual provisions may be used to extend or establish IP rights, such as providing reagents under a restrictive technology transfer agreement. Such contracts include: material transfer agreements between technology developers and third-parties, which limit the transfer and use of materials such as vectors, genes, and plants developed by the transferor; bag label contracts between the manufacturer and the buyer of, for example, seed, which limit further uses of purchased material that would otherwise be allowable; technology use agreements between technology suppliers and farmers, which

${ }^{14}$ European Patent Office, case number G 0001/98.

${ }^{15}$ See Alston and Venner (2000) for an analysis of the effects on private plant breeding of the 1970 U.S. Plant Variety Protection Act. 
typically control the right to plant a given seed on a specific area of land for a certain period of time; and licenses between patent or property holder and licensee, which are negotiated grants of some or all of the holder's rights, such as allowing the use and sale of the technology.

Some genetic technologies impose technical limits on farmers' use of seeds from their harvest to replant or to sell for replanting. The most common is production of hybrid crops that generally have a lower yield through loss of "hybrid vigor" if replanted. Modern alternatives include genetic use restriction technologies (GURTs) that confer sterility on replanted seeds and are called varietal GURTs—-popularly dubbed terminator technologies_- or that control the expression of specific traits in seeds, called traitGURTs (CBD/SBSTTA 1999).

\section{INFRINGEMENT AND THE FREEDOM TO OPERATE}

Infringement and remedies. The nature of the patent system in the North makes it important for plant breeders to pay close attention to freedom to operate in order to avoid infringement. Infringement of a patent involves the unauthorized making, using, selling, or offering to sell the patented invention within the territory that granted the patent, or importing the patented invention into that same country during the term of the patent. ${ }^{17}$ The patent right is exclusionary, and the patentee must know of the alleged infringement if she is to defend her right. Her first action upon identification of an alleged infringer is typically to inform him of her patent rights, and either offer to negotiate a license, or ask that the infringement cease. If unsatisfied by the response, the patentee can sue for relief

\footnotetext{
${ }^{16}$ UPOV Convention, 1991 Act. Details available from UPOV (2000).

${ }^{17}$ Furthermore, TRIPs allows a patent owner to prohibit importation of products made by processes patented in the importing country. Article 28.1(b) of TRIPs Agreement.
} 
in the appropriate court. The patentee may ask the court for an injunction to prevent the continuation of the infringement and may also ask the court for an award of damages.

In an infringement suit, the defendant may raise the question of the validity of the patent, which is then decided by the court. The defendant may also argue that what is being done does not constitute infringement. Infringement is determined primarily by the language of the claims of the patent. If what the defendant is making does not fall within the language of any of the claims of the patent, there is no infringement.

It can be extremely costly to pursue or defend against a claim of infringement. In the United States, where each party pays its own costs (other than in exceptional circumstances), a minimum estimate for litigation is $\$ 500,000$, and cases often cost each party several million dollars net of any damages awarded. ${ }^{18}$ Thus, the stakes are high and it behooves a manufacturer to avoid infringement. Unfortunately, in agricultural biotechnology, this can be difficult, as the number of patents is rapidly increasing, and the breadth of claims of some patents, the existence of multiple patents with applicable claims, and the slow pace of legal resolution of validity combine to make practice of basic technologies difficult, or at least legally hazardous, especially in the United States. In Europe, as well as some other countries, the validity of a patent grant can be challenged within the European Patent Office, but only for a limited time after the patent is allowed. ${ }^{19}$ This procedure, known as an opposition, is an inter partes proceeding between the patentee and the challenger. The United States patent law does not allow

${ }^{18}$ Lerner (1995, p. 470) reports that for every 100 United States biotechnology patents, there are six patent suits, an extremely high figure relative to other areas of technology. He further estimates that patent litigation in the U.S. Patent Office and the federal courts initiated in the year 1991 lead to total legal expenditures of \$1 billion 1991 U.S. dollars, compared with U.S. \$3.7 billion spending by firms on basic research in that year. Note that the cost figure excludes litigation in state courts.

${ }^{19}$ In Europe the opposition period is nine months after grant. 
opposition, but instead has a limited reexamination proceeding, which reexamines the patent only with regard to prior art not considered during examination.

The freedom to operate. There is a tension inherent in IP between its rationale — the provision of incentives for the development and dissemination of new technology — and the freedom to operate. The broader the monopoly rights conferred by IP, the larger the potential threat to the freedom to operate of innovators.

Assuming key technology is subject to a valid IPR in the jurisdiction in question, there are, broadly speaking, two kinds of obstacles to the freedom to operate. First, owners of technology may be unwilling to share or license it, or only do so after costly negotiations. Thus, it may be difficult to obtain essential research inputs. Second, owners of technology may litigate against alleged infringers, forcing the latter to incur the cost of assessed damages, and, in at least some European countries (e.g., United Kingdom), the patentee's legal defense if found to be infringing. In other jurisdictions, including the United States, even a victorious litigant usually has to pay her legal costs. Thus, prospective inventors must beware of IP claims on which their research inputs, processes, or research outputs might infringe or be alleged to infringe. These two kinds of obstacles are often closely connected. A tradeoff may occur between them: prospective technology users may have to weigh the risk of litigation against the costs or difficulties of obtaining licenses.

The diversity of innovations utilized in developing modern cultivars (cultivated varieties) can result in a balkanization of technologies due to conflict between the many competing parties holding rights— be they patents or assigned use rights via commercial contracts or licenses — to these technologies. This balkanization can seriously threaten to hinder subsequent innovation. Furthermore, as patenting becomes even more prevalent 
in biotechnology, the number of separate rights needed to produce a new innovation proliferates. If ownership of these rights is diffuse and uncertain, the multilateral bargaining problem can become difficult if not impossible to resolve. This is the "tragedy of the anticommons" noted by Heller and Eisenberg (1998).

The tragedy of the anticommons can be seriously compounded by uncertainty. Those who develop new technology, building on existing technologies, often know neither the extent to which the latter have been claimed as IP, nor the strength of any claims. The conduct of $\mathrm{R} \& \mathrm{D}$ and subsequent commercialization entail navigating a potential minefield of patent applications that have been filed but remain invisible pending publication by the patent office. ${ }^{20}$ Public breeders in the United States received a nasty surprise when a patent issued to Monsanto on the CaMV 35S promoter surfaced after they had used it in the breeding of crop cultivars on the brink of commercialization. More generally, individual inventors in the United States such as Jerome Lemelson became notorious for continuing prosecution of patent applications for long periods of time as others became locked in to their technology, then extracting large rents from infringements after the patent was issued. ${ }^{21}$ The uncertainty emanating from submarine patents is becoming less important as the United States has harmonized with the rest of the world by awarding a patent term of 20 years from the date of filing (previously 17 years from the date the patent was awarded) as well as beginning in November 2000 publishing patent applications within 18 months of filing. Publication may be excepted

${ }^{20}$ Such patents are sometimes called submarine patents.

${ }^{21}$ This scenario could generally only be enacted in the United States, which does not allow public access to on-going patent prosecution; until 1 November 2000 did not publish patent applications; and prior to 7 June 1995 awarded patent terms for 17 years commencing from the date of issue. 
by petition, but only if the application is not the basis for an application filed in another country that does publish applications. ${ }^{22}$

IP strategies in light of the freedom to operate. The concept of freedom to operate is fundamental to the effective development and commercialization of any innovation and is particularly crucial in agricultural biotechnology in light of recent developments. Research providers and commercial entities need to be able to conduct their business without infringing on rights held by others. It should never be assumed that a license to use critical enabling technologies would be made available. If a research program or commercialization proceeds under the assumption that its implementation will ultimately be allowed, future negotiations may be placed in serious jeopardy. The negotiating position of the innovator typically deteriorates as innovation progresses.

In some situations, companies or public institutions controlling the IP rights may adopt a policy of not granting a license and instead retain the sole right to the use of the technology for commercial development or license it exclusively to an entity that will not grant others a license. Research licenses may be relatively easily obtained, but licenses to commercialize research outcomes can be more difficult to acquire; for example, IP owners may seek unreasonable or commercially unacceptable terms. Such companies have the power to block the commercial applications of the technology by their competitors or their acquisition targets. For instance, the Centre for Legumes in Mediterranean Agriculture (CLIMA) in Australia developed a transgenic lupin cultivar with tolerance to the herbicide Basta, ${ }^{\circledR}$ but have been unable to reach agreement with AgrEvo (now Aventis) to commercially release the plant (Ewing 2000). Likewise, researchers at Michigan State University developed a new turfgrass containing a

\footnotetext{
${ }^{22}$ Some exceptions to publishing are allowed in the United States, but are not
} 
proprietary gene from one company and a promoter from another. Neither company would give permission for its material to be used in conjunction with that from another company, and so the turfgrass has been destroyed (Erbisch 2000).

Thus, where key technology is covered by IP rights, the commercialization of most biotechnology-based developments of value may be difficult or impossible. As indicated above, much of the key technology is owned by multinational companies, and in at least a few cases, licenses on these technologies are not being provided or are not offered with acceptable conditions. With respect to the small set of commercially important crops, such behavior might reflect aggressive business strategies being used by these private corporations, for whom controlling equity is the main consideration, rather than license revenue per se. For the vast majority of crops that constitute less attractive technology markets, withholding a license might imply a reluctance to expose the IP holder to liability for damages or to hazards to its reputation.

\section{THE INTERNATIONAL DIMENSION OF INTELLECTUAL PROPERTY ${ }^{23}$}

It is vitally important to keep in mind that there is no such thing as an "international intellectual property right." ${ }^{24}$ A patent or other IP right awarded in one country, for example the United States, does not confer property rights in the rest of the world. Patents and other IP rights are awarded by national governments, and the protection conferred extends only as far as the geographic boundaries of the country in

expected to have a major impact in agricultural biotechnology.

${ }^{23}$ Sources used in compiling this subsection include Gutterman and Anderson (1997), Barton (1998), Chisum and Stuart (1998), Walden (1996), and Long and D’Amato (2000).

${ }^{24}$ While the focus here is on patents and plant breeders' rights, we are mindful that international treaties, especially for copyrights, can bind parties to granting" full faith and credit" to the rights holder of another member country, thus in effect providing international protection. 
which the right is awarded. Thus, to obtain protection in several countries, rights must be applied for and awarded in each. ${ }^{25}$

International treaties and organizations do, however, play an important role in IP rights. The primary purposes of international treaties on IP are to facilitate obtaining protection in multiple countries and to provide a uniform, minimal set of laws and standards in subscribing countries. Through treaties, countries may commit themselves to future changes in their laws and possible deadlines for implementing those changes.

International treaties on IP date back to the $19^{\text {th }}$ century. The Paris Convention (1883) for the Protection of Industrial Property, which covers trademarks, patents, and trade secrets, and the Berne Convention (1886) for the Protection of Literary and Artistic Works, which covers copyrights, are still relevant to IP, although both have been revised and supplemented by later treaties. These treaties are now administered by the World Intellectual Property Organization (WIPO), a specialized agency of the United Nations. The international trade aspects dealt with in this paper mean that a number of more recent treaties are also noteworthy: The International Convention for the Protection of New Varieties of Plants (known as the "UPOV Convention," after a French acronym) of 1961 (revised in 1978 and 1991); the European Patent Convention (1977); the Patent Cooperation Treaty (1978), supplemented by the Patent Law Treaty (2000); the Convention on Biological Diversity (Biodiversity Convention, 1992), and the Agreement on Trade Related Aspects of Intellectual Property Rights (TRIPs 1994).

The European Patent Convention (EPC) established the European Patent Office (EPO), which now coexists with national patent offices. Persons wishing to acquire a

${ }^{25}$ Regional patent offices, such as the European Patent Office (EPO), serve to streamline the patent procedure. To be valid in individual European countries, a patent 
patent for member states of the European Union may apply for national patents either through the EPO or through Patent Offices in the individual countries. Once granted, the "European patent" can take effect as a national patent in all or a designated number of member states upon registration, payment of fees, submission of appropriately translated documents, and miscellaneous other formalities. Any infringement of the European patent is thereafter dealt with by the national courts. ${ }^{26}$ For this reason, a European patent, though granted by the EPO, is not truly an international patent, but rather a bundle of national patents. ${ }^{27}$

The Patent Cooperation Treaty (PCT) is a special agreement under the Paris Convention among some 108 members of the Convention. The Paris Convention provides for the equal treatment toward nationals among member states with respect to patent rights. The PCT permits an applicant to make a single filing of a patent specification within 12 months of an initial filing in a national patent office. The applicant then has up to 30 months from the initial national application to file in designated countries according to their national procedures and criteria for granting or rejecting a patent. ${ }^{28}$ At the time of conversion, filing fees must be paid in each country. In summary, the PCT facilitates lodgment of patent applications in multiple countries, but

awarded by the EPO must be registered in each country, although it does not undergo further examination.

${ }^{26} \mathrm{EPC}$, Article 64.

${ }^{27}$ The filing in the EPO can be made in German, French or English. The filing fee depends in part on how many EP countries are designated. Annuities are paid to the EPO while prosecution is on-going. Once the grant is made and the patent is registered in the individual countries, the applicant pays annuities to each country. Also translation is made at the time of registration-Danish for Denmark, and so on. The annual fees are comparatively inexpensive in early years, but increase over time.

${ }^{28}$ Patents cannot be sought retroactively; at the critical time-points rights must be pursued. Thus, in the PCT process, countries in which an applicant might seek protection must be explicitly designated at the time of PCT application. Likewise, application to a 
does not furnish an international patent. Recently, member states of the World Intellectual Property Organization have adopted by consensus an international treaty that will simplify and streamline procedures for obtaining and maintaining a patent. The Patent Law Treaty (PLT), which has been opened for signature, will enter into force once ten countries have ratified it. ${ }^{29}$ The PLT achieves a major goal of international simplification by incorporating the requirements for PCT international applications into national and regional laws. Thus, under the PLT, the requirements and procedures for national and regional patent applications, and those for PCT international applications, will be harmonized. This will eventually lead to standardized formal requirements and streamlined procedures for all patent applications worldwide.

The Convention on Biological Diversity (CBD) also contains some provisions on IP rights, although the main aims of the CBD are conservation of biological diversity, sustainable use of its components, and the fair and equitable sharing of the benefits arising out of the utilization of genetic resources. ${ }^{30}$ In particular, Article 16(5) recognizes that intellectual property rights may have an influence on the implementation of the CBD and further obliges member states to cooperate in order to ensure that IP rights are "supportive of and do not run counter to" the objectives of the CBD. So that Parties can gain access to technology, member states must take appropriate measures, which furthermore are consistent with international law and are mutually agreed upon. ${ }^{31}$

country not party to the PCT but party to the Paris Convention must be made within 12 months of the initial national filing.

${ }^{29}$ See the WIPO website: http://www.wipo.int/news/en/index.html?wipo content frame=/pressroom/en/index.htm, Press Release PR/2000/224,Geneva, June 2, 2000. See also The Economist, June 17, 2000.

${ }^{30}$ Article 1, Convention on Biological Diversity. Details from UNEP (2000).

${ }^{31}$ Article 16(3) and 16(4). 
Essentially, the CBD preserves the rights of intellectual property owners as they are defined in international law, such as TRIPs.

Although aspects of IP protection may vary among countries, the TRIPs Agreement sets out minimum standards that each country belonging to the World Trade Organization (WTO) must implement. These standards have been discussed above. One of the most critical provisions, Article 27(1) of TRIPs, requires member states (about three-quarters of the world's countries) to allow patents for any inventions, "whether products or processes, in all fields of technology." While this Article settled the longstanding conflicts over pharmaceutical product patents, Article 27 has created new complications regarding protection for biological matter and agricultural biotechnology in particular. The complications arise from the vagueness of Article 27(1) and exceptions to patentability allowed under Articles 27(2) and (3).

Because TRIPs does not define the term "invention," countries can determine that biological matter, such as genes, are merely a "discovery" and not an invention. Indeed, some countries are implementing legislation along these lines. ${ }^{32}$ In addition, exceptions are allowed in order to protect order public; human, animal and plant life; and avoid serious harm to the environment.

More importantly, Article 27(3)(b) allows members to exclude from patentability "plants and animals other than micro-organisms as well as essentially biological processes for their production". The breadth of this exception is hotly debated, and the Article is under review by WTO member states. Thus, there is much uncertainty about what biological matter can be excluded. Although members are not required to allow

${ }^{32}$ Decision 486, Article 15, promulgated by the Andean Community (Bolivia, Colombia, Ecuador, Peru and Venezuela) deems that biological material that exists in 
plants to be patented, they must nevertheless provide protection of plant varieties, either by patents or by an "effective sui generis system" or by combination of both systems. This is a major change for most developing countries, which previously did not provide protection for plant varieties.

Much has been written about what constitutes an effective sui generis system and the latitude that countries have in determining the scope and content of the rights to be granted (see, for example, Leskien and Flitner 1997). Such a discussion is beyond the scope of this paper. Suffice it to say that while plant protection systems are relatively well established in developed countries, lesser-developed countries are currently struggling with how to comply with this provision of TRIPs. Because developing countries are unlikely to implement patent protection for plants, there will likely be a great deal of variability in rights accorded in each country.

A number of countries, mostly developed countries however, have subscribed to a particular sui generis system, the International Convention for the Protection of New Varieties of Plants (UPOV). The rights accorded under UPOV extend not only to the plants but also to plant parts, harvested materials, and "essentially derived variet[ies].,"33 Moreover, in the 1991 Act, the "farmers' exemption" that allows farmers to save seed for re-propagation is not required to be implemented by member states, but may be established.

Thus, it appears that in the fields of agriculture and agricultural biotechnology the type and scope of protection will vary greatly from country to country, and especially

nature or can be isolated from any life form is not an invention (Commission of the Andean Community 2000).

${ }^{33}$ Article 14, UPOV 1991. 
from North to South. Overall, this makes it more difficult to assess freedom-to-operate on an international level.

\section{THE FREEDOM TO OPERATE IN AGRICULTURAL R\&D FOR DEVELOPING COUNTRIES}

There is widespread misunderstanding regarding IPR and freedom to operate in developing countries. A survey (Cohen et al, 1998) of the use of proprietary biotech research inputs at selected CGIAR Centers showed considerable confusion on the part of researchers regarding the existence of relevant IPR and freedom to operate. The report itself does not distinguish local validity of IPR from existence of IPR in some jurisdiction. As emphasized above, patents are valid only in countries in which they are issued.

Many current key technologies for plant breeding appear to be unprotected in developing countries. For example, in the case of plant transformation technology, particle bombardment technology appears to be controlled primarily by Monsanto/Agracetus and Dupont, with a complex web of cross-licensed partners. The key Agrobacterium technology for plant transformation is more diversely held in different implementations by numerous patents applied for, and patents awarded in different jurisdictions (United States, Europe, Australia, Canada, and Japan) to Monsanto, the Max Planck Institute, AstraZeneca/Mogen, Novartis, Japan Tobacco, and many others. The most widely used selectable markers for cereal transformation are controlled by Aventis/AgrEvo (phosphinothricin, Basta®); Monsanto (a particular implementation of the kanamycin resistance gene or G418 under control of CaMV 35S or 19S promoters); or Novartis (hygromycin resistance), which is patented or pending in Australia, Canada, Europe, the United States, Hungary, Ireland, Russia, Japan, Israel, 
Greece, and Denmark. ${ }^{34}$ Possibly the most widely used promoter is the CaMV 35S promoter, which intellectual property is owned by Monsanto. Patents for the CaMV 35S technology have been granted only in the United States and Europe, ${ }^{35}$ and the only pending application is in Japan. ${ }^{36}$ Patents in the United States claiming portions of the CaMV 35S promoter are held by Rockefeller University. Thus, there are no IP restrictions in less-developed countries on the use of these commonly employed genes.

The freedom to operate in R\&D depends on choices_especially those concerning litigation, threats of litigation, and the grant or sale of use rights—made by owners of relevant proprietary technologies. In addition to IP laws, the incentives that shape these choices are affected by an array of factors, some of which are biosafety regulations, public relations, implementation of laws, and market characteristics. Biosafety regulations are closely related to IP in biotechnology. In particular, in some countries official approval is required for the use, sale, and/or importation of transgenic crop or animal varieties. Just like IP or any other laws, biosafety regulations are primarily national in nature, while being affected by international treaties. ${ }^{37}$

Due to consumer resistance to agricultural biotechnology, the degree of which varies considerably among different countries, public relations are a serious issue for multinationals active in the field. For instance, a multinational may be reluctant to litigate against a nonprofit research agency for fear of damage to its public image and to its relations with governments and lawmakers of developing countries. In particular,

\footnotetext{
${ }^{34}$ The filings were made in 1982-83 when neither Greece nor Denmark was part of the European Patent Office.

${ }^{35}$ European Patent EP 131623 B2 and United States Patent Nos. 5,034,322, $5,352,605$, and 5,858,742.

${ }^{36}$ United States Patent nos. 5,352,605; 5,530,196; and 5,858,742; and European Patent, EP 131 623, which is currently being opposed.

${ }^{37}$ Such as the Biosafety Protocol, agreed upon in Montreal in January 2000.
} 
multinationals will try to avoid being seen as obstacles to applications of technologies that benefit poor farmers and consumers. However, it would be a serious mistake to rely on such forbearance as a matter of policy, as implied by RAFI (2000, p. 31). If the stakes are high enough, multinationals have been willing to incur a good deal of opprobrium in enforcing their intellectual property rights against farmers in Canada and the United States. Moreover, owners of IPR include specialized smaller companies that have no reputation or goodwill to protect, and the need for cash that motivates them to protect their IPR wherever infringement occurs. The Enola bean and Texmati rice U.S. patent controversies are instructive here.

Jurisdictions also differ in the extent to which their laws are actually implemented. Knowledge of a country's IP and biosafety laws is necessary for assessing the local freedom to operate, but may not be sufficient. In addition to the possibility of the official law being implemented imperfectly, or not at all, one must beware of de facto rules that are not officially codified as law.

Among the many factors that affect the freedom to operate, we focus on a subset of market characteristics, namely global production and trade patterns. The willingness of owners of agricultural technology to cede use rights, or the minimum price at which they are willing to sell the rights to others is shaped, among other things, by the location and structure of crop production and, particularly, the pattern of trade. There are two, often overlapping, sets of circumstances under which the freedom to operate in agricultural research may not be under serious threat.

First, proprietary technologies that are targeted at commercially unattractive markets may be transferred free of charge. Crops grown for subsistence use in developing countries are clearly of little commercial interest to developed-country 
multinational companies. In addition, technologies used in crops that are sold primarily to poor consumers in developing countries may not be of much commercial interest to multinationals. Thus, a grant of technologies owned by these multinationals to develop crops growing in those circumstances is, with some caveats, a realistic possibility. In fact, multinationals have, in several prominent cases, donated technologies to nonprofit agricultural research agencies working on behalf of poor farmers in the developing world. Public-relations considerations are likely to play an important role in such cases. Sometimes, more complex market segmentation deals are announced, in which commercially viable uses of the technology are separated from uses that are of humanitarian rather than commercial value.

A well-publicized example of such a complex arrangement is the GoldenRice ${ }^{\mathrm{TM}}$ Vitamin A Rice Project in which AstraZeneca cooperated with nonprofit organizations to put nutritionally enhanced golden rice seeds containing a gene owned by AstraZeneca in the hands of poor farmers at no charge. GoldenRice ${ }^{\mathrm{TM}}$ contains enhanced levels of provitamin A in the endosperm of the seed (which remains after the rice is polished), which is potentially of great health benefits to millions of poor farmers and consumers in developing countries. AstraZeneca has acquired the commercial rights to GoldenRice ${ }^{\mathrm{TM}}$ from Greenovations, a small German company acting as an intermediary for the inventors. In return, AstraZeneca has licensed the inventors to enable distribution of the rice on a royalty-free basis to farmers who earn less than $\$ 10,000$ per year and live in developing countries, leaving the company free to explore commercial prospects for the technology (Tait and Wrong 2000). In addition, Monsanto announced its intent to provide royalty-free licenses for all its technologies that support the further development of GoldenRice ${ }^{\mathrm{TM}}$ (Monsanto 2000), and other IP holders have followed suit. 
Second, anyone is free to use technologies and know-how in crops that are developed, produced, and consumed in countries where the technology is not subject to local IP protection, irrespective of whether the crop is grown on a subsistence or commercial basis and whether the technology is subject to IP protection in other jurisdictions. This fact appears to be overlooked in discussion of the GoldenRice ${ }^{\mathrm{TM}}$ example and makes it difficult to know exactly what is being "donated" in prominent cases. According to Kryder et al. (2000), there are 70 patents associated with this technology, including both process patents (relevant to creation of the technology) and product patents (embodied in the rice itself). This case has been quoted as posing a nightmare with respect to freedom to operate, and so the Monsanto and AstraZeneca donations generated a grateful response. But what did poor rice consumers gain from the donations? Table 1 shows the top 15 rice importers, and the number of Vitamin A rice technology patents valid in each. It is clear that for most of the developing countries in the list few or no patents associated with Vitamin A rice are valid in each. And these numbers are overestimates. Some of the patents may not cover the application to Vitamin A rice, and others may be later invalidated.

Assuming Table 1 is correct, importation of Vitamin A rice into Iran from Bangladesh infringes no patents. Crops that are traded among countries in which the technologies are not subject to IP are not liable to claims based on the use of these technologies. But importers of Bangladeshi Vitamin A rice into Japan might be subject to successful prosecution for infringement of claims to any embodied material covered by Japanese patent claims. This could be so even if technologies are unencumbered by IP in Bangladesh. 
Table 1 Vitamin A Rice Patents in Rice-Producing and Rice-Importing Countries

\begin{tabular}{lrlr}
\hline Top 15 Rice- & Nomber of Patents & Top 15 Rice- & Importing Countries \\
Producing Countries & 11 & Iran & Number of Patents \\
\hline China & 5 & Brazil & 0 \\
India & 6 & Nigeria & 10 \\
Indonesia & 0 & The Philippines & 0 \\
Bangladesh & 9 & Iraq & 1 \\
Vietnam & 0 & Saudi Arabia & 0 \\
Thailand & 0 & Malaysia & 0 \\
Myanmar & 21 & South Africa & 0 \\
Japan & 1 & Japan & 5 \\
The Philippines & 10 & Côte D'Ivoire & 21 \\
Brazil & 44 & Senegal & 10 \\
United States & 10 & United Kingdom & 10 \\
South Korea & 0 & France & 35 \\
Pakistan & 0 & Indonesia & 37 \\
Egypt & 0 & United States & 6 \\
Nepal & & & 44 \\
\hline
\end{tabular}

Source: Kryder et al. (2000, table 4).

Thus, developing-world crop breeders have freedom to operate with respect to crops produced in developing countries unencumbered by local IP protection of relevant inputs, processes, or products, and which, in addition, do not constitute infringing imports into countries in which IP protection prevails. IP problems might arise in technologies destined for crops grown in developing countries unencumbered by IP restrictions if those crops are subsequently exported in a form in which infringement is detectable to countries in which IP is likely to prevail. Note that in such cases it is the importer, not the breeder, who may be infringing on IP.

Specific technologies may have IP protection in some developing countries (like Brazil, China, and Argentina) but not in others. The details would need to be considered on a case-by-case basis. Identification of those countries in which IP has been assigned 
for a specific technology is an essential task in delineation of traders' freedom to operate. It is also important to keep in mind the large number of relevant technologies that are typically involved in breeding a modern crop cultivar, as the Vitamin A rice example illustrates.

This is one element of the multi-pronged approach needed for managing and developing an IP strategy to allow breeders to pursue their missions. Determination of freedom to operate requires technical knowledge, a broad business overview, detailed understanding of patent claims in all relevant countries, understanding of markets and national jurisdictions, and knowledge of litigation and negotiation procedures in relevant jurisdictions. A comprehensive assessment of all these aspects is well beyond the scope of this paper.

In the next section we confine our attention to global production and trade patterns as a basis for assessing the impact of developed-country IPR on producers in developing countries with no relevant IPR, using new technologies and following recent trade patterns. Although production and consumption in such countries would not infringe, development of germplasm that infringes in the North could be problematic if the technology embodied in the product infringes patents in major export markets.

\section{PRODUCTION AND TRADE PATTERNS AND THE FREEDOM TO OPERATE}

Understanding the production and trade status of crops relevant to developing countries is not only important in helping to ascertain the implications of intellectual property rights but is also helpful to those endeavoring to structure assignments of use rights by the private sector to public and nonprofit plant breeders. The plant breeders we 
have in mind might work in national public-sector agencies or for nonprofit organizations with a focus on agriculture in less-developed economies. To make the analysis concrete, we focus on crops that are covered by the international agricultural research centers (IARCs) that are members of the CGIAR. These include many of the crops most important to research agencies operating in less-developed economies, with tropical beverages being major exceptions.

\section{DATA SOURCES AND TREATMENT}

International production patterns for crops considered here drew from the on-line FAOSTAT database of the Food and Agriculture Organization of the United Nations. Crop production is reported on a calendar-year basis and refers to harvested production. Export values and corresponding quantity totals were obtained from FAOSTAT's "Agriculture and Food Trade" domain, wherein the trade data are classified according to the international SITC (revision 2) standard. The import and export totals by country reported in appendix tables 3a-d were obtained from FAO's "Commodity Balances" domain. They represent the total amount of each commodity traded (irrespective of its source or destination) in its primary-equivalent form. Appendix table 1 details the regional groupings of countries we used, and appendix table 2 provides details of the commodity categories included in the FAOSTAT (and COMTRADE) data used for this study.

To quantify bilateral trade flows among developing and developed countries for the CGIAR crops we used the Commodity Trade Statistics Data Base (COMTRADE) compiled by the United Nations Statistics Division. These data include annual trade statistics since 1962 lodged by about 110 countries. The United Nations Statistics Division convert value-of-trade data to current U.S. dollars using exchange rates 
supplied by each reporting country, or a weighted average exchange rate derived from monthly market rates. Wherever possible, trade volumes and quantities (if reported) are expressed in metric units.

For our analysis we used annual SITC (revision 3) data for the period 1992-98. Presuming trade statistics reported by developed countries are generally more reliable than those from developing countries, we estimated annual bilateral trade flows by querying the COMTRADE database treating developed countries as "reporters" and developing countries as "partners." Using this approach, we compiled a series that includes annual trade flows among 29 developed countries treated as reporters, and 168 developing countries and areas treated as partners (see appendix table 1 for a listing of countries). ${ }^{38}$ Thus "exports from developing countries" was our estimate of the imports reported by the developed countries from developing countries. Exports are valued in fob (free-on-board) prices, imports mainly in cif (cost, insurance, and freight) prices, and thus the reported total value of imports is generally larger than the corresponding value of exports. $^{39}$

Agricultural commodities are traded in raw or primary and various processed forms. For example, wheat is traded as grain, flour, pasta, bran, starch, and so on, soybeans, as grain, crude and refined oil, oil cake, and soy sauce. We compiled the COMTRADE data at the most disaggregated level available to us in the SITC 3 series, namely the five-digit level. Most of the CGIAR crops are specifically represented at this level of disaggregation; the omissions are yams, sweet potatoes, cowpeas, pigeon peas,

${ }^{38}$ Transition economies — principally the countries that formed part of the former Soviet Union—are not included in any of the bilateral trade flow evidence based on COMTRADE data.

${ }^{39}$ The exceptions are Canada, Mexico, and Australia whose imports are reported in fob prices. 
and plantains. Yams and sweet potatoes are lumped under "other roots, tubers" along with other products. Pigeon peas and cowpeas are most likely included under "other legumes." Plantains are grouped under "bananas fresh or dried." We recorded all identifiable forms of each CG crop. These were summed to form the respective commodity trade totals. ${ }^{40}$ In total, 53 product categories were aggregated into 15 commodity totals (appendix table 2). It is possible that some fraction of these commodities was traded in some form not specified in the SITC Revision 3 series, but the degree of under-reporting for this reason is believed to be small.

\section{INTERNATIONAL PRODUCTION AND TRADE TOTALS}

Using the FAO series, table 2 summarizes the 1997 production and international trade performance of the 20 crops currently researched by the CGIAR, arranged into three country groupings - the developing countries, transition economies, and the world. Columns a, c, and g report the 1997 quantity of exports from developing countries, transitional economies, and the world, respectively; columns b, d, and h give the quantities produced for these same regional groupings. Columns a/f and c/f report the quantity of developing and transitional country exports expressed as a share of world exports while columns $\mathrm{b} / \mathrm{g}$ and $\mathrm{d} / \mathrm{g}$ give the corresponding regional quantities produced as a share of total world output. Column a/b expresses developing-country exports as a share of developing-country production; column c/d gives the same ratio for the transition economies, and f/g the corresponding ratio for the world. Crops were grouped according

${ }^{40}$ The COMTRADE product categories, reported in value terms, were simply summed irrespective of form. We did not attempt to convert the value data into some type of primary-form equivalent. To do so requires, at a minimum, that corresponding quantity data for each commodity category for each country and for each year are available, but such data are only reported for some countries and commodities for several years. 
Table 2 Production and Trade Indicators, 1997

\begin{tabular}{|c|c|c|c|c|c|c|c|c|c|c|c|c|c|c|}
\hline & \multicolumn{5}{|c|}{ Developing Countries ${ }^{1}$} & \multicolumn{5}{|c|}{ Transition Economies $^{1}$} & \multicolumn{4}{|c|}{ World $^{1}$} \\
\hline & \multicolumn{2}{|c|}{ Exports } & \multicolumn{2}{|c|}{ Production } & \multirow[b]{2}{*}{$\begin{array}{c}\text { Share } \\
\text { Exp/Prod } \\
\end{array}$} & \multicolumn{2}{|c|}{ Exports } & \multicolumn{2}{|c|}{ Production } & \multirow[b]{2}{*}{$\begin{array}{c}\text { Share } \\
\text { Exp/Prod }\end{array}$} & \multicolumn{2}{|c|}{ Exports } & \multirow[b]{2}{*}{ Production } & \multirow[b]{2}{*}{$\begin{array}{c}\text { Share } \\
\text { Exp/Prod }\end{array}$} \\
\hline & Quantity & $\begin{array}{c}\text { Share } \\
\text { Exp/Wexp }\end{array}$ & Quantity & $\begin{array}{c}\text { Share } \\
\text { Pdn/WPdn }\end{array}$ & & Quantity & $\begin{array}{c}\text { Share } \\
\text { Exp/Wexp }\end{array}$ & Quantity & $\begin{array}{c}\text { Share } \\
\text { Pdn/WPdn }\end{array}$ & & Value & Quantity & & \\
\hline Column code & $\begin{array}{c}\mathrm{a} \\
(1,000 \mathrm{mt})\end{array}$ & $\begin{array}{c}\mathrm{a} / \mathrm{f} \\
\text { (percentage) }\end{array}$ & $\begin{array}{c}\mathrm{b} \\
(1,000 \mathrm{mt})\end{array}$ & \multicolumn{2}{|c|}{ (percentage) } & $\begin{array}{c}\mathrm{c} \\
(1,000 \mathrm{mt})\end{array}$ & $\begin{array}{c}\mathrm{c} / \mathrm{f} \\
\text { (percentage) }\end{array}$ & $\begin{array}{c}\mathrm{d} \\
(1,000 \mathrm{mt})\end{array}$ & $\begin{array}{l}\mathrm{e} / \mathrm{g} \\
\quad(\text { perce }\end{array}$ & $\begin{array}{c}\mathrm{c} / \mathrm{d} \\
\text { ntage) }\end{array}$ & $\begin{array}{c}\mathrm{e} \\
(U S \$ m l s .)\end{array}$ & \multicolumn{2}{|c|}{$(1,000 \mathrm{mt})$} & $\begin{array}{c}\mathrm{f} / \mathrm{h} \\
\text { (percentage) }\end{array}$ \\
\hline \multicolumn{15}{|l|}{ Cereals } \\
\hline Rice & 22,630 & 76.2 & 613,623 & 95.2 & 3.7 & 128 & 0.4 & 1,203 & 0.2 & 10.6 & 7,660 & 29,693 & 644,818 & 4.6 \\
\hline Wheat & 15,268 & 12.1 & 285,793 & 46.8 & 5.3 & 7,374 & 5.8 & 116,427 & 19.1 & 6.3 & 20,641 & 126,093 & 610,546 & 20.7 \\
\hline Maize & 22,639 & 22.4 & 263,992 & 40.6 & 8.6 & 1,884 & 1.9 & 45,215 & 7.0 & 4.2 & 14,069 & 101,016 & 650,113 & 15.5 \\
\hline Sorghum & 809 & 12.7 & 43,619 & 69.4 & 1.9 & 2 & 0.0 & 67 & 0.1 & 3.2 & 769 & 6,373 & 62,822 & 10.1 \\
\hline Millet & 108 & 46.9 & 26,344 & 93.5 & 0.4 & 21 & 9.1 & 1,616 & 5.7 & 1.3 & 55 & 230 & 28,187 & 0.8 \\
\hline Barley & 1,800 & 7.0 & 24,854 & 16.0 & 7.2 & 2,342 & 9.1 & 47,951 & 30.9 & 4.9 & 3,788 & 25,752 & 154,984 & 16.6 \\
\hline \multicolumn{15}{|c|}{ Roots, Tubers, Banana, and Plantain } \\
\hline Cassava & 11,220 & 94.2 & 164,909 & 100.0 & 6.8 & 0 & 0.0 & 0 & - & - & 2,801 & 11,905 & 164,909 & 7.2 \\
\hline Sweet Potato & 55 & 67.7 & 128,363 & 98.5 & 0.0 & 2 & 2.0 & 0 & - & - & 34 & 82 & 130,257 & 0.1 \\
\hline Potato & 970 & 7.2 & 111,747 & 38.6 & 0.9 & 357 & 2.6 & 98,273 & 34.0 & 0.4 & 2,553 & 13,494 & 289,345 & 4.7 \\
\hline Banana & 12,137 & 90.1 & 57,616 & 98.4 & 21.1 & 72 & 0.5 & 0 & - & - & 4,707 & 13,464 & 58,562 & 23.0 \\
\hline Yam & 23 & 99.8 & 30,037 & 98.9 & 0.1 & 0 & - & 0 & - & - & 18 & 23 & 30,376 & 0.1 \\
\hline Plantain & 143 & 90.9 & 29,629 & 100.0 & 0.5 & 0 & 0.0 & 0 & - & - & 58 & 157 & 29,629 & 0.5 \\
\hline \multicolumn{15}{|l|}{ Food Legumes } \\
\hline Soybeans & 60,626 & 51.5 & 171,570 & 46.4 & 35.3 & 422 & 0.4 & 1,840 & 0.5 & 23.0 & 33,522 & 117,802 & 369,961 & 31.8 \\
\hline Beans & 1,848 & 74.5 & 14,559 & 86.0 & 12.7 & 7 & 0.3 & 562 & 3.3 & 1.2 & 1,323 & 2,482 & 16,932 & 14.7 \\
\hline Chickpeas $^{2}$ & 378 & 48.8 & 8,104 & 96.6 & 4.7 & 0 & - & 5 & 0.1 & - & 301 & 775 & 8,389 & 9.2 \\
\hline Pigeonpeas $^{2}$ & 7 & 100.0 & 2,866 & 100.0 & 0.2 & 0 & - & 0 & - & - & 3 & 7 & 2,866 & 0.2 \\
\hline Cowpeas $^{2}$ & 20 & 86.5 & 2,383 & 98.0 & 0.8 & 0 & - & 37 & 1.5 & - & 5 & 23 & 2,433 & 1.0 \\
\hline Lentils $^{2}$ & 322 & 46.5 & 2,179 & 79.5 & 14.8 & 0 & - & 9 & 0.3 & - & 329 & 693 & 2,742 & 25.3 \\
\hline \multicolumn{15}{|l|}{ Oil Crops } \\
\hline Coconut & 30,005 & 90.6 & 99,708 & 98.4 & 30.1 & 11 & 0.0 & 0 & - & - & 8,629 & 33,131 & 101,333 & 32.7 \\
\hline Groundnuts & 3,450 & 75.7 & 60,461 & 94.9 & 5.7 & 37 & 0.8 & 150 & 0.2 & 24.7 & 3,650 & 4,560 & 63,702 & 7.2 \\
\hline
\end{tabular}

Source: Compiled from FAOSTAT (2000) "Commodity Balances" for columns a, b, c, d, f, and g. To estimate column e, we formed a price (i.e., unit value) by dividing the total value of exports by the corresponding total quantity for each commodity in its primary form, reported in FAOSTAT"s "Agriculture and Food Trade" domain. We used this price to weight the total traded quantities reported in the Commodity Balances data obtained from FAO.

Note: "Exp" denotes exports; "wexp" denotes world exports; "prd" denotes production; and "wprd" denotes world production. All products are in crop-primary-equivalent form. In the production totals we also estimated and included production of oils and cakes that were converted in primary-equivalent form using average world conversion factors taken from FAO (2000). See Appendix Table 2 for details on product categories. Within each crop class, crops are arranged in descending order at 1997 developing-world production (column b).

1. Includes 124 developing and 27 transitional countries, and 178 countries in the world total.

2. For these crops, production data were taken from the "Agricultural Production" domain of FAOSTAT (2000). 
to CGIAR "areas of research," and within each group reported in descending order according to the quantity of production in developing countries (column b).

At least 95 percent of the world's production of rice, cassava, sweet potatoes, yams, bananas, plantains, chickpeas, pigeon peas, cowpeas, groundnuts and coconuts takes place in poor countries, as does 94 percent of the millet production and over two thirds of the sorghum output. (column b/g). ${ }^{41}$ Poor countries produce a smaller but still significant share (46 percent) of global soybean production. Production of cereals other than rice is more geographically disbursed. Less than 50 percent of the world's production of wheat, maize, and barley is grown in the developing world, with the transition economies being significant producers of barley and wheat.

For many of the crops in table 2, total exports from developing countries represent a minor share of total developing-country production (column $\mathrm{a} / \mathrm{b}$ ). Developing-country exports of sweet potato, yam, plantain, chickpea, cowpea, pigeon pea, and millet are negligible (column a). Virtually all the production and consumption of these crops takes place in the developing world. For groundnuts and rice, slightly larger shares—but still less than 6 percent —of developing-country production is exported. More substantive but still comparatively small shares of developing-country bean and lentil production, as well as wheat, maize, and barley production, are exported. About one-fifth of the developing world's banana production, and one-third of its soybean production are exported.

Appendix tables $3 a$ through d give a more detailed country-by-country picture of the pattern of production. Countries are grouped into developing, developed, and transitional regions and commodities ranked within their respective group according to

${ }^{41}$ The status of cooking bananas in FAOSTAT is not entirely clear, but we surmise they are usually lumped together with dessert bananas under the heading of "bananas." 
their share of 1997 production. As expected, the larger countries such as China, Brazil, India, and Indonesia figure prominently among the top 10 developing-country producers for many, but not all, of the commodities. Few African countries figure among the top 10 cereal and food legume producers, but do appear more frequently among the top 10 producers of root crops, groundnuts, and, especially, plantains (and cooking bananas), where African countries account for almost three-quarters of world production. Plantain exports are small, but this crop is a very significant source of starch in African diets.

\section{SOUTH-NORTH TRADE FLOWS}

Table 3 summarizes the annual average trade flows between developing countries and the developed world for 15 CG commodities for the period 1994-98 using the COMTRADE data. The top panel in table 3 reports the value of developed-country exports to and from the developing world. The two right-hand columns indicate the overall developed-country trade balance, both in total and with respect to trade with developing countries. Developed countries are net exporters of wheat, maize, potatoes, sorghum, and lentils to the developing world, and net importers of all other crops in the table.

Developing countries as a group both import and export virtually all the crops. In part, this reflects seasonal differences in production and differences in the quality and form of the crops being traded. By total value, wheat is the major developed-country export crop with a developing-country destination—averaging more than $\$ 10.7$ (current prices) billion per year (column a)—followed by soybeans ( $\$ 4.5$ billion), maize ( $\$ 4.3$ billion), barley ( $\$ 1.1$ billion), and rice (\$982 million). As a developing-country export crop to the developed world, wheat ranks a distant sixth (column c). The top-ranking exports from LDCs to the developed world by value are soybeans, bananas, rice, and 
Table 3 Developed-Country Trade, 1994-98 Annual Average

\begin{tabular}{|c|c|c|c|c|c|c|}
\hline & \multicolumn{2}{|c|}{ Exports } & \multicolumn{2}{|c|}{ Imports } & \multicolumn{2}{|c|}{ Balance of Trade } \\
\hline & to LDCs & Total & from LDCs & Total & with LDCs & Total \\
\hline \multirow{2}{*}{\multicolumn{2}{|c|}{ Annual trade flows }} & $\mathrm{b}$ & $\mathrm{c}$ & $\mathrm{d}$ & $\mathrm{e}$ & $\mathrm{f}$ \\
\hline & & \multicolumn{2}{|c|}{ (thousand U.S. dollars) } & & & \\
\hline Soybean & $4,466,762$ & $10,440,702$ & $5,145,713$ & $11,118,853$ & $(678,951)$ & $(678,151)$ \\
\hline Bananas & 3,555 & 888,659 & $4,651,434$ & $5,379,999$ & $(4,647,879)$ & $(4,491,339)$ \\
\hline Rice & 982,054 & $2,305,332$ & $1,242,062$ & $2,596,468$ & $(260,008)$ & $(291,136)$ \\
\hline Coconut & 28,675 & 197,949 & $1,177,257$ & $1,331,826$ & $(1,148,582)$ & $(1,133,877)$ \\
\hline Groundnut & 63,764 & 491,664 & 669,741 & $1,095,247$ & $(605,976)$ & $(603,583)$ \\
\hline Wheat & $10,676,906$ & $21,261,677$ & 600,116 & $11,400,189$ & $10,076,789$ & $9,861,488$ \\
\hline Cassava & 893 & 45,440 & 507,791 & 562,058 & $(506,898)$ & $(516,618)$ \\
\hline Maize & $4,293,828$ & $9,192,626$ & 434,742 & $5,823,624$ & $3,859,086$ & $3,369,001$ \\
\hline Beans & 199,408 & 472,547 & 326,179 & 664,494 & $(126,772)$ & $(191,947)$ \\
\hline Potato & 601,064 & $4,154,037$ & 236,214 & $3,732,855$ & 364,850 & 421,182 \\
\hline Chickpeas & 60,390 & 76,105 & 92,021 & 106,974 & $(31,631)$ & $(30,870)$ \\
\hline Sorghum & 355,282 & 745,732 & 82,319 & 530,640 & 272,963 & 215,093 \\
\hline Lentils & 83,322 & 162,396 & 21,826 & 95,439 & 61,496 & 66,956 \\
\hline Millet & 3,216 & 32,231 & 16,590 & 51,609 & $(13,373)$ & $(19,378)$ \\
\hline Barley & $1,103,922$ & $2,433,878$ & 4,618 & $1,443,621$ & $1,099,303$ & 990,257 \\
\hline Total & $22,923,040$ & $52,900,975$ & $15,208,623$ & $45,933,896$ & $7,714,417$ & $6,967,078$ \\
\hline \multicolumn{5}{|c|}{ Share of commodity total } & & \\
\hline Soybean & 19.49 & 19.74 & 33.83 & 24.21 & & \\
\hline Bananas & 0.02 & 1.68 & 30.58 & 11.71 & & \\
\hline Rice & 4.28 & 4.36 & 8.17 & 5.65 & & \\
\hline Coconut & 0.13 & 0.37 & 7.74 & 2.90 & & \\
\hline Groundnut & 0.28 & 0.93 & 4.40 & 2.38 & & \\
\hline Wheat & 46.58 & 40.19 & 3.95 & 24.82 & & \\
\hline Cassava & 0.00 & 0.09 & 3.34 & 1.22 & & \\
\hline Maize & 18.73 & 17.38 & 2.86 & 12.68 & & \\
\hline Beans & 0.87 & 0.89 & 2.14 & 1.45 & & \\
\hline Potato & 2.62 & 7.85 & 1.55 & 8.13 & & \\
\hline Chickpeas & 0.26 & 0.14 & 0.61 & 0.23 & & \\
\hline Sorghum & 1.55 & 1.41 & 0.54 & 1.16 & & \\
\hline Lentils & 0.36 & 0.31 & 0.14 & 0.21 & & \\
\hline Millet & 0.01 & 0.06 & 0.11 & 0.11 & & \\
\hline Barley & 4.82 & 4.6 & 0.03 & 3.14 & & \\
\hline Total & 100 & 100 & 100 & 100 & & \\
\hline \multicolumn{5}{|c|}{ Share of respective import and export total } & & \\
\hline Soybean & 42.78 & 100 & 46.28 & 100 & & \\
\hline Bananas & 0.40 & 100 & 86.46 & 100 & & \\
\hline Rice & 42.6 & 100 & 47.84 & 100 & & \\
\hline Coconut & 14.49 & 100 & 88.39 & 100 & & \\
\hline Groundnut & 12.97 & 100 & 61.15 & 100 & & \\
\hline Wheat & 50.22 & 100 & 5.26 & 100 & & \\
\hline Cassava & 1.97 & 100 & 90.34 & 100 & & \\
\hline Maize & 46.71 & 100 & 7.47 & 100 & & \\
\hline Beans & 42.2 & 100 & 49.09 & 100 & & \\
\hline Potato & 14.47 & 100 & 6.33 & 100 & & \\
\hline Chickpeas & 79.35 & 100 & 86.02 & 100 & & \\
\hline Sorghum & 47.64 & 100 & 15.51 & 100 & & \\
\hline Lentils & 51.31 & 100 & 22.87 & 100 & & \\
\hline Millet & 9.98 & 100 & 32.15 & 100 & & \\
\hline Barley & 45.36 & 100 & 0.32 & 100 & & \\
\hline Total & 43.33 & 100 & 33.11 & 100 & & \\
\hline
\end{tabular}

Source: Compiled from United Nations Statistics Division COMTRADE database (1999).

Note: Crops are arranged in rank order of total imports from LDCs (column c). 
coconuts; each crop averaging more than one billion dollars per year, with soybean and banana exports averaging more than $\$ 4.5$ billion per year.

The middle panel of table 3 indicates the relative trade significance of each crop within the 15-crop trade total and highlights the fact that a small number of commodities account for the lion's share of the overall trade total. Wheat, soybeans, and maize combined account for more than 85 percent of all developed-country exports to the developing world among the 15 crops listed here, while soybeans and bananas account for about 60 percent by value of the developed-country crop imports from the developing world.

The bottom panel in table 3 gives the developed-country share of total imports and exports, respectively, that come from and go to developing countries. Comparatively large shares—more than 40 percent—of the developed world's wheat, sorghum, maize, rice, barley, beans, and soybeans exports go to the developing world. The preponderance of the developed world's banana, coconut, cassava, and chickpea imports come from developing countries. Notably, wheat originating from developing countries is less than 6 percent of the total developed-world wheat imports (whereas Southern rice is 48 percent of total Northern rice imports while LDC maize accounts for only 7 percent of the developed world's total maize imports).

The trade flows between the developed and developing worlds are summarized graphically in figure 1, restating some of the data presented in the upper panel of table 3. Commodities in this figure are sorted in descending order, from left to right, according to the total value of developed-country imports from the developing world (column c table 3). The trade balance for developing countries for these $15 \mathrm{CG}$ commodities is negative overall (column e table 3), due mainly to substantial developed-country wheat and maize 
exports to the developing world. The only sizable exports from LDCs to developed countries are soybeans and bananas, followed well behind by rice, coconuts, and groundnuts. South-North exports of most of the other ten commodities are minimal.

Figure 1 Trade Between Developed and Developing Countries, 1994-98 Annual Averages

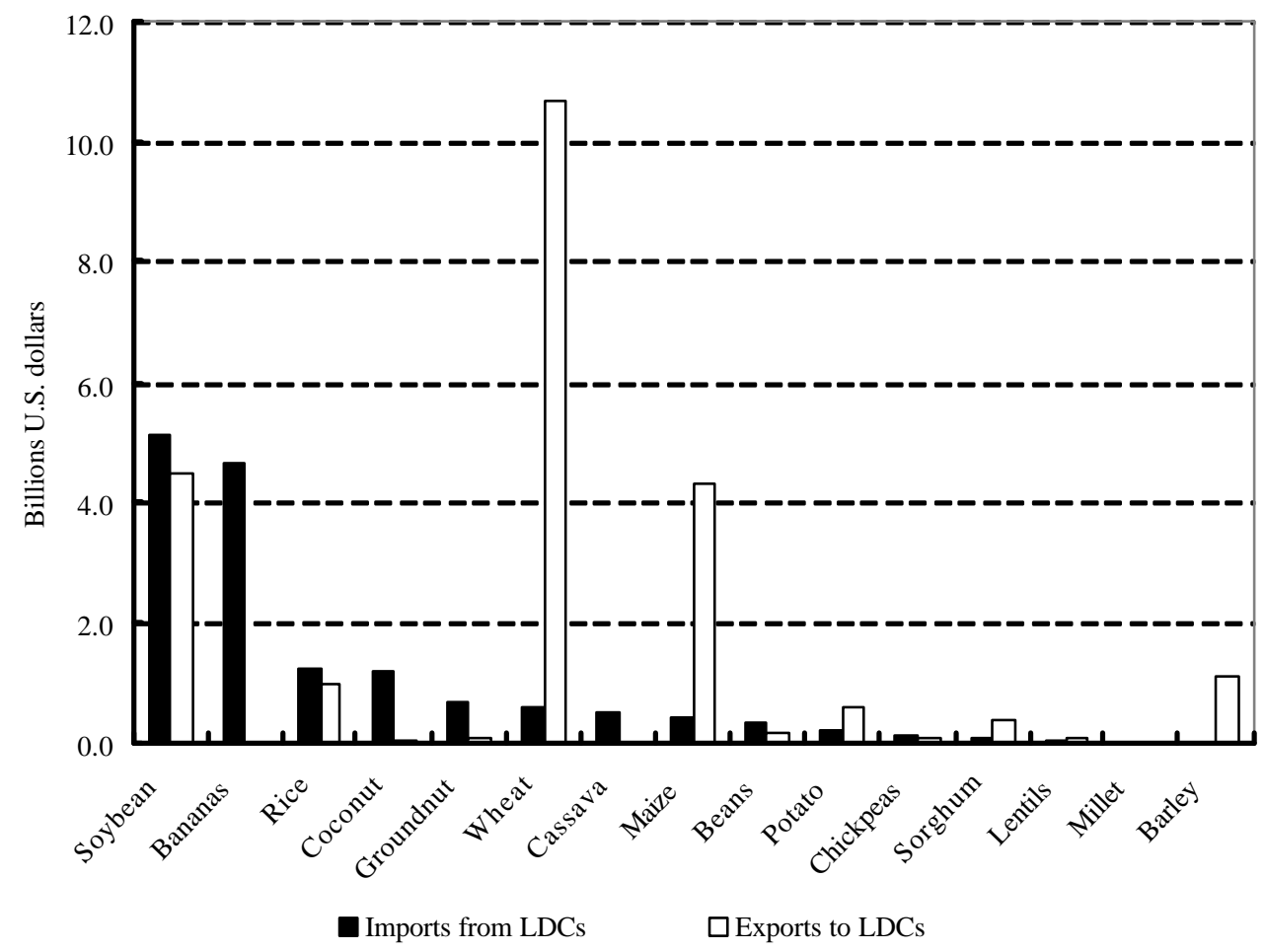

Source: Compiled from United Nations Statistical Division COMTRADE database (1999).

Developing-country exports to the developed world are not only concentrated in a few commodities, as depicted in figure 1, but the preponderance of exports originates from comparatively few countries. Just 9 LDC countries shipped 76 percent of the $15-$ crop total exports to the developed world (table 4). Soybeans, the number one LDC export crop by value to the developed world (nearly 34 percent of the 15 -crop total), came mainly from Brazil and Argentina. A sizable share of developing-country rice 
exports to the developed world was from Thailand (59 percent of total LDC rice exports to the developed countries), bananas came mainly from Costa Rica and Ecuador (each about 20 percent of total LDC-to-developed-country banana exports), and coconut exports were principally from the Philippines. Generally more than 50 percent of total LDC exports to the developed world for each crop originated from just one or two countries, and for each of Brazil, Costa Rica, Ecuador, Colombia, and Panama, over 97 percent of these exports involved just one of the crops considered. Over 80 percent of the crop exports from Thailand and Argentina involved just two commodities—rice and cassava in the case of Thailand, and soybeans and groundnuts in the case of Argentina.

Appendix tables 4a-o give more detailed region-to-region, country-to-region, and country-to-country trade flows for the $15 \mathrm{CG}$ crops. These more spatially refined data serve to reinforce the finding described above that comparatively few LDC countries account for most of the total LDC exports to the developed world. Additionally, most of these LDC exports go to Western Europe (about 64 percent), followed by the United States (16 percent) and Japan (11 percent). Western Europe is the principal developedworld destination for developing-country exports of all but $3 \mathrm{CG}$ commodities, the exceptions being wheat, sorghum, and barley.

It takes many years to bring new agricultural ideas and inventions to market. With this in mind, how indicative of future trade patterns are annual trade flows over recent past years and thus the likely freedom to operate of LDCs in future years? To gain a sense of the stability of the geographic pattern of South-North trade we tracked trade trends back to 1992. Total developed-country imports of the $15 \mathrm{CG}$ crops grew from $\$ 41$ billion in 1992 to $\$ 49$ billion by 1996, dropping to $\$ 44$ billion in 1998 (figure 2). 
Table 4 Developing-Country Exports to the Developed World-Top Nine Countries, 1994-98 Averages

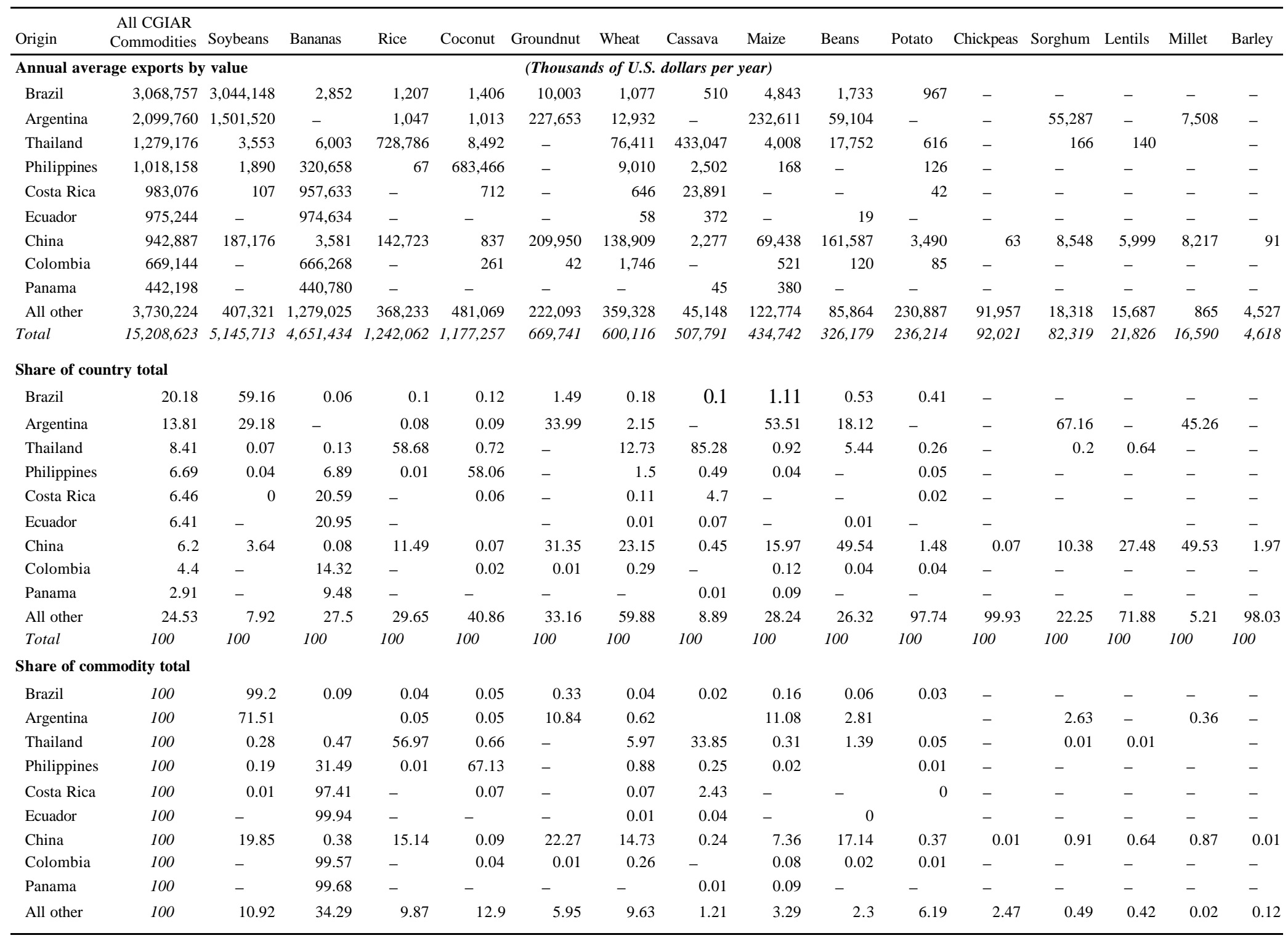

Source: Compiled from United Nations Statistics Division COMTRADE database (1999). 


\section{Figure 2 Total Developed-Country and World Imports}

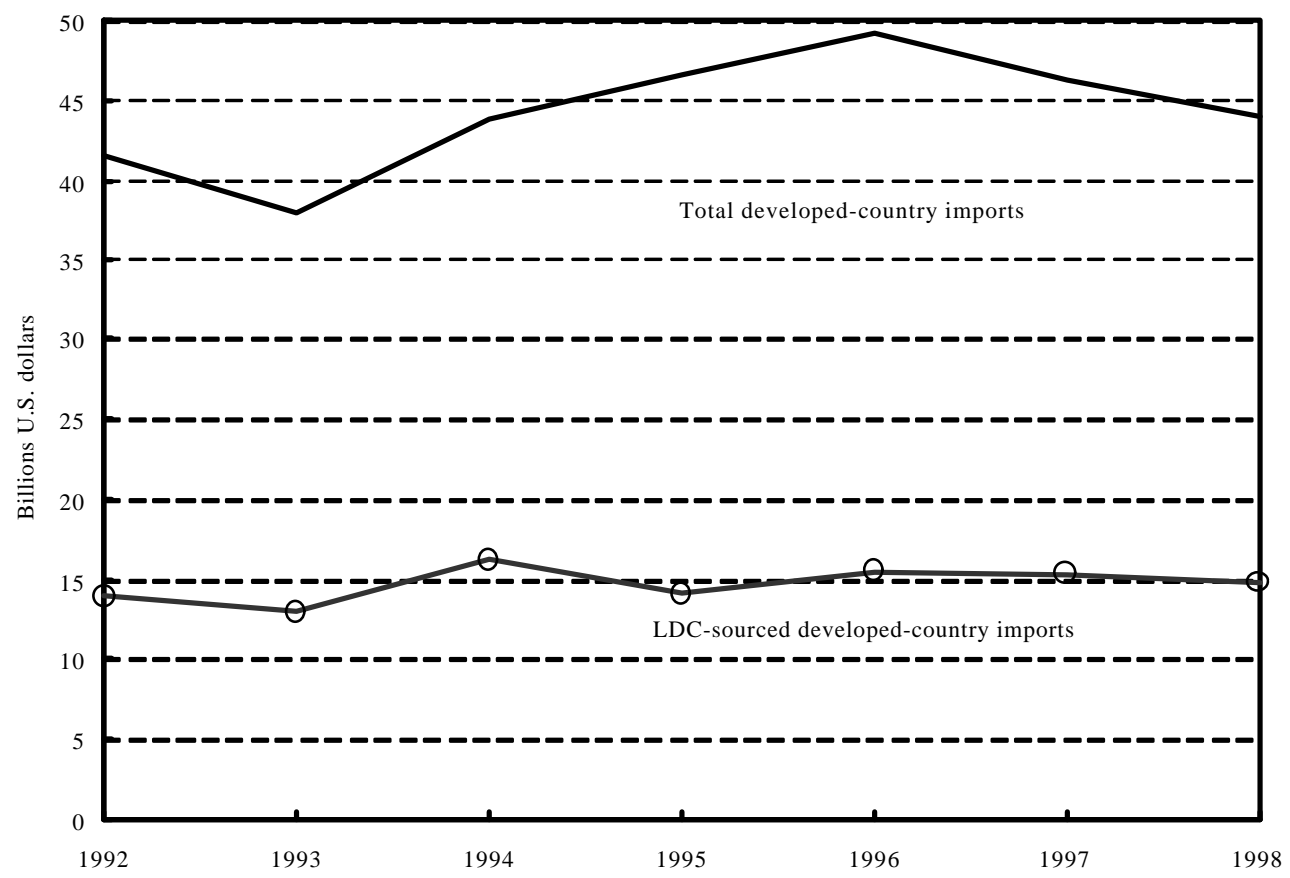

Source: Compiled from United Nations Statistics Division COMTRADE database (1999).

This amounts to an annual rate of growth of 2.5 percent from 1992-98. The value of developedcountry imports originating from LDCs grew by 1.7 percent per year. Despite some year-to-year variation in the LDC share of these developed-country imports, the share was comparatively stable, hovering around one third of the total. The pattern of country-to-county trade between North and South was also quite stable. The same five Southern countries generally dominated trade to the North for the years 1992 to 1998 for each of the 15 CG crops. $^{42}$

According to the COMTRADE data, the value of wheat and rice exports from the LDCs to the developed countries grew rapidly, by over 10 and 6 percent per year respectively since 1992. In contrast, LDC exports of barley, beans, cassava, chickpeas, lentils, maize, millet,

${ }^{42}$ While total South-North trade in each commodity came from just a few countries, in any one year up to 30 Southern countries shipped some (usually minimal) barley to the North 
potatoes, and sorghum to the developed world declined. These crop-specific patterns of trade over the 1992-98 period are reflected in figure 3, which plots the share of total developed country imports of each of the $15 \mathrm{CG}$ crops that originate in the LDCs for three sub-periods. The developed world relies little on the LDCs for its wheat and maize (and barley and potato) imports but a significant share of many of the other CG crop imports does come from the developing world. Notably the share of developed-country rice imports originating in developing countries grew considerably over the past years (29 percent in 1992 to 46 percent in 1998).

\section{Figure 3 Share of Developed-Country Imports Originating in LDCs}

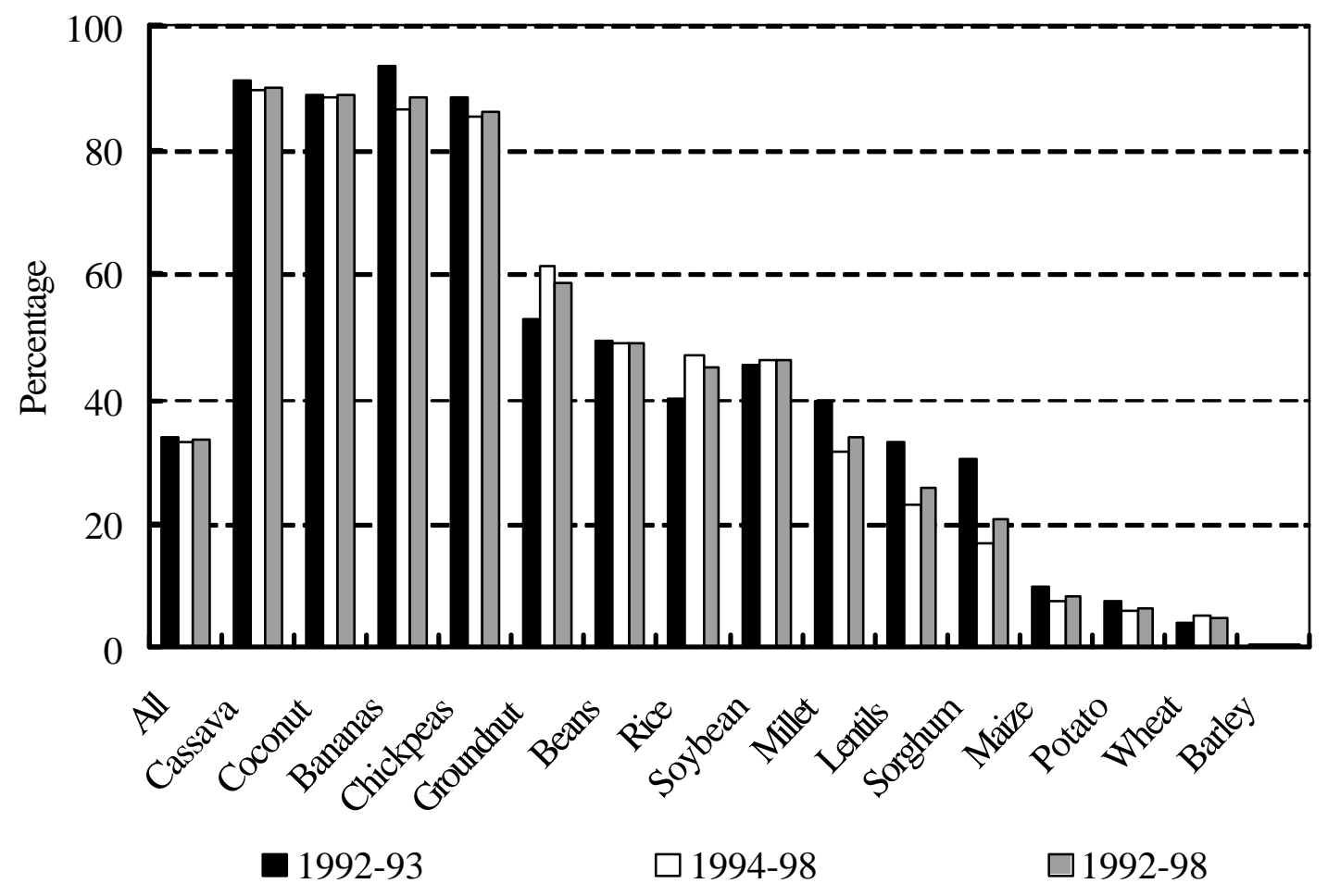

Source: Compiled from United Nations Statistical Division COMTRADE database (1999).

and 137 LDCs exported wheat to the developed world. The number of LDC countries shipping any of the remaining CG crops Northwards in any particular year was between 30 and 137. 
PROCESSED PRODUCTS, INFRINGEMENT, AND DETECTABILITY

To successfully litigate against the importation of crops that were developed with locally protected IP, the litigant must be able to establish the use of the IP. Many aspects of modern biotechnologies can be discerned in seeds and fruit parts, but not necessarily so if the crop is shipped in processed form. Tests based on protein or DNA, including sensitive polymerase chain reaction (PCR) based diagnostic methods, are largely if not wholly incapable of detecting substantive components of protected technologies in oils, carbohydrates, purified proteins, or some extracts. However, even if components are used and detected for which freedom to operate is available (e.g., public-domain or licensed selectable markers), some sort of evidence (e.g., subpoenaed notebooks) is necessary, to determine what process was used to generate the material. Hence it can be considered that the substantive versus methodological components of IP verification must be viewed as being separate. The substantive detection is almost completely useless in refined products such as oils, sugar, and pure fiber, but even when it shows positive results for a particular component in, say, soybean meal, there may still be substantial investigation required to establish whether a particular process was used to insert that component - a potentially costly piece of detective work. On the other hand, the burden of proof requirements may favor the patentee. For example, in the United States the presumption is that a product is made from a process patented in the U.S. when there is both a substantial likelihood of it and that the patentee made a reasonable effort to determine the process actually used. ${ }^{43}$ It then becomes the alleged infringer's burden to prove that the process was non-infringing.

While trade in processed products makes it more difficult to detect IP use, whether IP infringement is more or less likely to occur when trading products in processed versus raw form is difficult to judge. IP claims can pertain to products, processes (e.g., of methods for making a

4335 U.S.C. $§ 295$ (U.S. House of Representatives 2000). 
plant and methods for processing it), and to the processed products themselves. However the law is unsettled regarding the reach of infringement of method claims to products resulting from these methods. For example, there may be no infringement for importing a product made by a patented process if it is materially changed by subsequent processes (such as shipping oil derived from soybean varieties whose creation is subject to process patents). However, relying on public policy arguments espoused in legislative history, the U.S. Federal Circuit in Bio-Technology General Corp. v. Genentech Corp. found infringement even though a product was materially changed. ${ }^{44}$ The COMTRADE data show that about 60 percent (by value) of LDC exports of coconuts to the developed world are in the form of oil, and about 54 percent of soybean exports are so traded. In contrast, bananas and rice are shipped almost entirely in raw form, in which IP should be more readily detectable.

In summary, the production and trade reveal that:

- Exports from developing to developed countries of CG crops are insignificant in relation to total agricultural exports from developing countries, developed country imports, or even in relation to domestic agricultural production, except for a few commodities, and only a small number of developing countries.

- The developing countries as a group account for more than 90 percent (and for quite a few of these crops more than 98 percent) of the world's production of rice, millet, cassava, sweet potato, yam, banana, plantain, chickpeas, cowpeas, pigeon peas, groundnuts, and coconuts. They also account for over 65 percent of the world's production of sorghum, beans, and lentils.

- For most CG crops, trade is dwarfed by output, meaning that for the majority of these crops output is never traded across international borders. Soybeans, coconuts,

4438 USPQ2d 1321 (Fed. Cir. 996), in which the claim at issue recited a method of constructing a cloning vehicle and the imported product was a protein produced from a host cell containing the cloning vehicle. Compare this case to Eli Lilly \& Co. v. American Cyanamid Co., 38 USPQ2d, 1705 (Fed. Cir. 1996), in which the Federal Circuit held that an imported compound produced by a claimed method for an intermediate compound was not infringing. 
bananas, lentils, and beans are the only crops of the 15 studied for which more than 10 percent of developing-country production is exported.

- Just 2 crops (soybeans and bananas) account for 64 percent of LDC crop exports to the developed countries and just 4 countries (Brazil, Argentina, Ecuador and Costa Rica) account for 42 percent of the South-North trade in these 2 crops. Adding in exports of rice and coconuts amounts to 80 percent of the South-North trade total, with most of the rice shipments destined for the developed world coming from Thailand and coconuts from the Philippines.

- The principal destination for South-North trade in 9 of the top 10 developing-country crop exports—specifically soybeans, bananas, rice, coconuts, groundnuts, cassava, maize, beans, and potatoes - is Western Europe. Wheat is the only exception. To the extent that it is exported from LDCs it is mainly shipped to North America and Japan. However, these exports are dwarfed by wheat trade in the reverse direction from North America to LDCs.

Soybeans, the most valuable developing country export crop, is of minor importance in most LDC research portfolios. However, given the significance of soybean exports from Brazil and Argentina (accounting for 79 percent of South-North trade in this crop), a few comments on these are in order. In 1999, genetically modified soybeans occupied 90 percent of soybean acreage in Argentina (James, 2000 p.9). Roundup resistant seeds, reputedly smuggled from Argentina (Feder 1999), were planted on an estimated 8 percent of Brazilian soybean acreage, ${ }^{45}$ notwithstanding that such seeds are still outlawed in Brazil. ${ }^{46}$

Roundup Ready ${ }^{\mathrm{TM}}$ soybean technology is not patented in Argentina, although seeds with this technology are generally protected under Argentina's 1974 seed law. ${ }^{47}$ This case vividly

${ }^{45}$ See http://www.asa-casa-ssa.org/dbrief/

46 This was confirmed in a recent decision of the Regional Federal Court in Brazil against Monsanto, which can appeal the decision to the Supreme Tribunal of Justice, Brazil's Supreme Court (Rich 2000).

47 The GAO (2000 p.6) reports “Monsanto’s 1995 application for a patent for Roundup Ready soybeans in Argentina was rejected. Monsanto appealed the decision, and an Argentine court overturned the rejection. Monsanto has petitioned for reconsideration of the patent application; as of December 1999, the application was pending." 
highlights the local nature of IP—presently the only property rights to Roundup technology in Argentina are assigned to plant breeders whose seeds embody this technology (not to Monsanto, the technology's inventor). Thus, it is not illegal for Argentine seed companies to incorporate this technology in their seeds absent licensing agreements with Monsanto, although the shipment of soybeans grown from such seeds into the United States would make importers liable to litigation.

In a search of PCT applications and issued United States and European patents, we found only three PCT patent applications directly related to transgenic bananas. Several others recite banana viruses and detection methods. However, there is IP pertaining to biotechnologies in commercially grown bananas due to patents whose claims encompass bananas (e.g., claims to monocots). The three principal fruit types of the genus Musa are dessert bananas, cooking bananas, and plantains. ${ }^{48}$ The vast majority of bananas that are exported by LDCs are dessert bananas. Cooking bananas and plantains are important in terms of production and consumption but not in terms of exports. International (nonprofit) plant-breeding research deals with all three Musa types although CGIAR research is mostly confined to cooking bananas and plantains. ${ }^{49}$

An important South-North trade development noted above is the rapid rise in rice exports from LDCs to developed countries. They increased at a rate of over 6 percent per year from 1992 to 1998, with an average of 47 percent of all Northern rice imports in 1994-98 originating from Southern countries. Rice is the third most significant CG crop among the Northern imports

\footnotetext{
${ }^{48}$ The status of cooking bananas in FAOSTAT is not entirely clear, but we surmise they are lumped together with dessert bananas under the heading of "bananas."

49 The International Institute for Tropical Agriculture (IITA)—a CGIAR center-conducts research on cooking bananas and plantains. The International Network for the Improvement of Bananas and Plantains (INIBAP), a program operated by the International Plant Genetic Resources Institute (IPGRI)—also a CGIAR center-, facilitates the international exchange of materials and technologies relating to all three Musa types, but does none of its own breeding. The Centre de cooperation internationale en researche agronomique pour le
} 
from LDCs. In the 1994-98 period, just a few countries (Thailand, India, China, and Netherlands Antilles $^{50}$ ) accounted for over 99 percent of South-North trade in rice, with Thailand responsible for 59 percent of the LDC rice exports to the developed countries. There is probably potential for further growth, and the capacity is certainly there, as rice exports from LDCs to the developed world are still dwarfed by domestic production in the LDCs.

In summary, the trade data suggest the conclusion that freedom-to-operate problems are most likely—among the crops under consideration— to arise in soybeans, bananas, and rice. However, soybeans are not at present the major focus of public research, whether by national or international agricultural research organizations working in or on behalf of the developing world. The types of bananas that dominate as an LDC food crop do not figure significantly in trade. And the percentage of rice output traded to the North is very small.

\section{CONCLUSION}

Many are concerned that rights over IP have locked out or severely curtailed LDC and international research agencies from access to and use of biotechnologies important for achieving necessary increases in the world food supply over the next several decades. According to our assessment this is not so- there is still substantial freedom to operate regarding research on most crops of most significance for food security in poor countries. While definitive views about the freedom to operate in any specific circumstance depend on the specifics regarding claims of the IP and the spatial pattern of IP, crop production, and trade, IP rights over biotechnologies

developpement (CIRAD), smaller in size but roughly comparable in objectives to the CGIAR, operates a banana breeding program that emphasizes dessert bananas (Buddenhagen 1996).

${ }^{50}$ According to FAO (2000), the Netherlands Antilles does not grow measurable amounts of rice. Its Northern exports consist largely of transshipments from nearby Latin American countries such as Suriname. 
relevant to agriculture are mainly held in (and therefore mainly relevant to) rich-country jurisdictions.

Intellectual property rights in the North affect farmers in the South if they export infringing products to the North. However, South-North trade in the food staples is limited overall, and in terms of the number of crops and the number of LDC countries that are involved in any significant sense. IPR-based limitations on export markets for food staples that embody technologies protected only in the North should not in general be considered an important impediment to the use of these technologies in such crops in the South.

This does not mean that freedom to operate is not a problem for LDC research on exportoriented cash crops such as horticultural products, tropical beverages, or dessert bananas, or in those few instances where Northern exports of agricultural staples constitute a significant share of a country's total exports. This paper deals mainly with food crops of significance to poor people.

Undue concern about the freedom to conduct LDC research (or research by those working on behalf of LDCs) is misdirecting policy and practical attention away from the main constraints presently facing researchers on food crops for the South. The real constraints are an increasingly serious lack of investment in Southern research and a lack of local scientific skills to access the rapidly advancing stock of complex modern biotechnologies, whether they are protected by patents or not. ${ }^{51}$ Biotechnology is challenging the adaptive capacity that has enabled poor countries to benefit from the advances in plant genetics and other relevant technologies in the past half-century, and lagging public resources are not being replaced by

\footnotetext{
${ }^{51}$ Pardey, Roseboom, and Craig (1999) point to the growing gap leading up to the early 1990s between the intensity of investment in agricultural research conducted in the North and the South. This gap seems likely to have changed little, or if anything deteriorated further, during the past decade.
} 
private-sector investments. Failure to invest in the adaptive capacity needed to evaluate, access, and regulate the technologies being developed in the North is currently a far greater constraint than freedom to operate. The current confusion over this issue itself illustrates the lack of capacity of researchers and decision makers to handle questions relating to IPR and freedom to operate in LDC plant breeding.

For the future, the extent of patenting of key biotechnologies in the South may grow as compliance with the IPR provisions of the TRIPS agreement is implemented in the South. The form of this implementation with respect to plant-breeding technology, domestically and in important export markets, is a crucial issue for future national freedom to operate of LDC researchers, and for LDCs' freedom to trade in agricultural products, both South-North and South-South. This issue ranks with implementation of farmers' rights as an important policy concern for plant breeders, farmers, and the food consumers of the South. But domestic freedom to operate is generally the dominant IPR issue; exports of important food staples that dominate agriculture are not important growth drivers in most developing countries.

Misconception of their present freedom to operate is a threat to the effectiveness of bargaining by breeders of food crops for the South for access to the scientific outputs from the more than $\$ 7$ billion of private spending (1985 prices) on agricultural R\&D in OECD countries. Institutional innovations bridging the private-public divide are beginning to emerge (Fischer et al. 2000). It behooves all parties to have a proper picture of the present degrees of freedom regarding Southern agricultural R\&D in order both to strike effective deals when tapping Northern intellectual property on behalf of the world's poor, and to know when such deals are not needed. 


\section{REFERENCES}

Alston, J.M. and R.J. Venner. "The Effects of the U.S. Plant Variety Protection Act on Wheat Genetic Improvement." EPTD Discussion Paper No. 62 Washington D.C. International Food Policy Research Institute, May 2000.

Barton, J.H. "Acquiring Protection for Improved Germplasm and Inbred Lines.” chapter 2 of F.H. Erbisch and K.M. Maredia, eds. Intellectual Property Rights in Agricultural Biotechnology. Wallingford: CAB International, 1998.

Barton, J.H. and J. Strauss. Correspondence:"How Can the Developing World Protect Itself from Biotech Patent-holders?" 406, Nature (2000): 455.

Besen, S.M. and L.J. Raskind. "An Introduction to the Law and Economics of Intellectual Property.” Journal of Economic Perspectives Vol. 5 (1991): 3-27.

Binenbaum, E. and B. Wright. "On the Significance of South-North Trade in IARC Crops." Appendix C-3 in Report of the CGIAR Panel on Proprietary Science and Technology. SDR/TAC:IAR/98/7.1. Rome: Technical Advisory Committee of the CGIAR, 1998.

Buddenhagen, I. W. "Banana Research Needs and Opportunities." Chapter 1 of G.W. Persley, and P. George, Banana Improvement: Research Challenges and Opportunities. Banana Improvement Report No. 1. Washington, D.C: The World Bank, 1996.

CAMBIA (Center for the Application of Molecular Biology to International Agriculture). Intellectual Property Resource, Canberra, Australia, unpublished data, 2000.

Chisum, D.S. and A.W. Stuart. "Agricultural Biotechnology and the Law: Patents, Plant Patents, Plant Variety Certificates, and the Rise of Intellectual Property Rights in Biological Subject Matter." Chapter 32 in A. Altman (ed.), Agricultural Biotechnology, New York: Marcel Dekker, 1998.

Cohen, J.I., C. Falconi, J. Komen, and M. Blakeney. "Proprietary Biotechnology Inputs and International Agricultural Research.” ISNAR Briefing Paper No. 39. The Hague: International Service for National Agricultural Research, 1998.

Commission of the Andean Community. Decisión 486: Régimen común sobre propiedad industrial. Lima, September 14, 2000. http://www.comunidadandina.org/normativa/dec/D486.ht, accessed October 2000

DePalma, A. and S. Romero. "Crop Genetics On the Line in Brazil; A Rule on Seeds May Have Global Impact.” New York Times, May 16, 2000: C1, C28.

EPC (European Patent Commission). "Convention on the Grant of European Patents." Article 64. http://european-patent-office.org/legal/epc/e/contents.html, accessed June 2000. 
Erbisch, F.H. "Challenges of Plant Protection: How a Semi-Public Agricultural Research Institution Protects Its New Plant Varieties and Markets Them." presented at the workshop on the Impact on Research and Development of Sui Generis Approaches to Plant Variety Protection of Rice in Developing Countries, International Rice Research Institute, Los Baños, Philippines, February 16-18, 2000.

Ewing, M. Personal communication, CLIMA (Centre for Legumes in Mediterranean Agriculture), Perth, 2000.

FAO (United Nations Food and Agriculture Organization). FAOSTAT data files, http://faostat.fao.org/cgi-bin/nph-db.pl?subset=agriculture, accessed March 2000.

FAO (United Nations Food and Agriculture Organization). “Technical Conversion Factors (Tcf) For Agricultural Commodities" http://www.fao.org/WAICENT/FAOINFO/ECONOMIC/ESS/tcf.htm, accessed March 2000.

Fischer, K.S. J. Barton, G.S. Khush, H. Leung, and L. Cantrell. “Collaborations in Rice.” Science 290 (October 2000):279.

Feder, B. "Rocky Outlook for Genetically Engineered Crops." New York Times, December 20, 1999.

GATT (General Agreement on Tariff and Trade) Secretariat. The Results of the Uruguay Round of Multilateral Trade Negotiations: The Legal Texts. Geneva: GATT Secretariat, June 1994.

GAO (United States General Accounting Office). "Biotechnology: Information on Prices of Genetically Modified Seeds in the United States and Argentina." Washington D.C.: United States General Accounting Office, January 2000.

Gutterman, A.S. and B.J. Anderson. Intellectual Property in Global Markets: A Guide for Foreign Lawyers and Managers. London: Kluwer Law, 1997.

Heller, M.A. and R.S. Eisenberg. "Can Patents Deter Innovation? The Anticommons in Biomedical Research.” Science 280 (1 May 1998): 698-701.

James, C. “Global Status of Commercialized Transgenic Crops: 1999.” ISAAA Briefs No. 17. ISAAA (International Service for the Acquisition of Agri-biotech Applications): Ithaca, New York, 2000.

Kryder, R.D., S.P. Kowalski, and A.F. Krattinger. "The Intellectual and Technical Property Components of Pro-Vitamin A Rice (GoldenRice ${ }^{\mathrm{TM}}$ ): A Preliminary Freedom-ToOperate Review." ISAAA Briefs No. 20. ISAAA (International Service for the Acquisition of Agri-biotech Applications): Ithaca, New York, 2000.

Lerner, J. "Patenting in the Shadow of Competitors." Journal of Law and Economics Vol. 38 (1995): 463-95. 
Leskien, D. and M. Flitner. Intellectual Property Rights and Plant Genetic Resources: Options for a Sui Generis System. IPGRI Issues in Plant Genetic resources No. 6. Rome: International Plant Genetic Resources Institute, June 1997.

Lindner, R.K. "Prospects for Public Plant Breeding in a Small Country." Presentation at the ICABR (International Consortium on Agricultural Biotechnology Research) Conference, Rome, Italy, June 1999.

Long, D.E. and A. D’Amato. A Coursebook in International Intellectual Property. St. Paul: West Group, 2000.

Monsanto. "Monsanto adds Support for "Golden Rice: Opens its Genome Sequence Data to Worldwide Research Community." news release, http://www.monsanto.com/monsanto/mediacenter/2000/00aug4_goldenrice.html, August 2000.

NIH (United States National Institutes of Health). "Report of the National Institutes of Health Working Group on Research Tools." presented to the Advisory Committee to the Director, June 4, 1998 (downloaded from http://www.nih.gov/news/researchtools/)

Pardey, P.G., J. Roseboom, and B.J. Craig. "Agricultural R\&D Investments and Impact." Chapter 3 in J.M. Alston, P.G. Pardey, and V.H. Smith (eds.), Paying for Agricultural Productivity. Baltimore: Johns Hopkins University Press, 1999.

RAFI (Rural Advancement Foundation International). "In Search of Higher Ground: The Intellectual Property Challenge to Public Agricultural Research and Human Rights and 28 Alternative Initiatives.” Occasional Paper Series Vol. 6, No. 1, September 2000.

Rich, J.L. “Seed Setback for Monsanto.” New York Times, August 10, 2000, p.C3.

Sachs, J. "Sachs on Globalisation: A New Map of the World." The Economist, June 24, 2000, pp.81-3.

Tait, N. and M. Wrong. "Deal offers free GM rice to poor farmers while rich have to pay." Financial Times, London, May 16, 2000, as reproduced by Ag Biotech Infonet, http://www.biotech-info.net/deal_offers_free_rice.html).

The Economist. "Patent Law: Going Global.” June 17, 2000, p.83.

UNEP (United Nations Environment Programme). Convention on Biological Diversity, 5 June 1992 available from The Clearing-House Mechanism of the Convention on Biological Diversity website http://www.biodiv.org/chm/conv/default.htm, accessed October 25, 2000.

UNEP/CBD/SBSTTA (United Nations Environment Program/Convention on Biological Diversity/Subsidiary Body on Scientific, Technical and Technological Advice) "Consequences of the Use of the New Technology for the Control of Plant Gene Expression for the Conservation and Sustainable Use of Biological Diversity." paper 
presented at the fourth meeting of the Subsidiary Body on Scientific, Technical and Technological Advice, Montreal, June 1999.

UNSD (United Nations Statistics Division). COMTRADE data files, 1999 (accessed April 2000).

UPOV (International Convention for the Protection of New Varieties of Plants) of December 2, 1961, as Revised at Geneva on November 10, 1972, on October 23, 1978, and on March 19, 1991. http://www.upov.org/eng/convntns/1991/act1991.htm , accessed October 2000.

USPTO (United States Patent and Trade Mark Office). http://www.uspto.gov, accessed September 2000.

U.S. House of Representatives, Office of the Law Revision Council. law2.house.gov/download.htm, accessed November 2000.

Walden, I. "Intellectual Property Rights and Biodiversity." chapter 9 in M. Bowman and C. Redgwell, eds. International Law and the Conservation of Biological Diversity. London: Kluwer Law, 1996.

Wright, B.D. "Crop Genetic Resource Policy: The Role of Ex Situ Genebanks.” Australian Journal of Agricultural and Resource Economics 41,1 (March 1977): 81-115.

Wright, B.D. 1998. "Public Germplasm Development at a Crossroads: Biotechnology and Intellectual Property." California Agriculture 52(6) November/December: 8-13, 1998. 


\section{Appendix Table 1 Countries in Dataset}

\begin{tabular}{|c|c|c|c|c|}
\hline Region/Country & FAO & COMTRADE & Region/Country & FAO COMTRADE \\
\hline Developed Countries & & & Transition Economies & \\
\hline Australia & $\checkmark$ & $\checkmark$ & Albania & $\checkmark$ \\
\hline Austria & $\checkmark$ & $\checkmark$ & Armenia & $\checkmark$ \\
\hline Belgium & & $\checkmark$ & Azerbaijan & $\checkmark$ \\
\hline Bel-Lux & $\checkmark$ & & Belarus & $\checkmark$ \\
\hline Canada & $\checkmark$ & $\checkmark$ & Bosnia Herzg & $\checkmark$ \\
\hline China: Hong Kong & $\checkmark$ & & Bulgaria & $\checkmark$ \\
\hline Denmark & $\checkmark$ & $\checkmark$ & Croatia & $\checkmark$ \\
\hline Faroe Islands & & $\checkmark$ & Czech Republic & $\checkmark$ \\
\hline Finland & $\checkmark$ & $\checkmark$ & Estonia & $\checkmark$ \\
\hline France & $\checkmark$ & $\checkmark$ & Georgia & $\checkmark$ \\
\hline Germany & $\checkmark$ & $\checkmark$ & Hungary & $\checkmark$ \\
\hline Greece & $\checkmark$ & $\checkmark$ & Kazakhstan & $\checkmark$ \\
\hline Hong Kong & & $\checkmark$ & Kyrgyzstan & $\checkmark$ \\
\hline Iceland & $\checkmark$ & $\checkmark$ & Latvia & $\checkmark$ \\
\hline Ireland & $\checkmark$ & $\checkmark$ & Lithuania & $\checkmark$ \\
\hline Israel & $\checkmark$ & $\checkmark$ & Macedonia & $\checkmark$ \\
\hline Italy & $\checkmark$ & $\checkmark$ & Moldova Republic & $\checkmark$ \\
\hline Japan & $\checkmark$ & $\checkmark$ & Poland & $\checkmark$ \\
\hline Macau & $\checkmark$ & $\checkmark$ & Romania & $\checkmark$ \\
\hline Malta & $\checkmark$ & & Russian Federation & $\checkmark$ \\
\hline Malta and Gozo & & $\checkmark$ & Slovakia & $\checkmark$ \\
\hline Netherlands & $\checkmark$ & $\checkmark$ & Slovenia & $\checkmark$ \\
\hline New Zealand & $\checkmark$ & $\checkmark$ & Tajikistan & $\checkmark$ \\
\hline Norway & $\checkmark$ & $\checkmark$ & Turkmenistan & $\checkmark$ \\
\hline Portugal & $\checkmark$ & $\checkmark$ & Ukraine & $\checkmark$ \\
\hline Singapore & & $\checkmark$ & Uzbekistan & $\checkmark$ \\
\hline South Africa & $\checkmark$ & $\checkmark$ & Yugoslavia & $\checkmark$ \\
\hline Spain & $\checkmark$ & $\checkmark$ & & \\
\hline Sweden & $\checkmark$ & $\checkmark$ & & \\
\hline Switzerland & $\checkmark$ & $\checkmark$ & & \\
\hline United Kingdom & $\checkmark$ & $\checkmark$ & & \\
\hline United States & $\checkmark$ & $\checkmark$ & & \\
\hline
\end{tabular}

Note: Our regional groupings of countries generally follows FAOSTAT (2000), with the exception that we classified Hong Kong, and Singapore as developed countries while FAOSTAT groups them with developing countries. FAOSTAT also includes the counties we label as "Transition Economies" in their group of developed countries, but identifies them as "Transition Markets" in a separate sub-category. 


\section{Appendix Table 1 Countries in Dataset (continued)}

\begin{tabular}{|c|c|c|c|c|c|}
\hline Region/Country & FAO & COMTRADE & Region/Country & FAO & COMTRADE \\
\hline \multicolumn{6}{|l|}{ Developing Countries } \\
\hline Afghanistan & $\checkmark$ & $\checkmark$ & Côte d'Ivoire & $\checkmark$ & $\checkmark$ \\
\hline Af. Other NS & & $\checkmark$ & Cuba & $\checkmark$ & $\checkmark$ \\
\hline Algeria & $\checkmark$ & $\checkmark$ & Cyprus & $\checkmark$ & $\checkmark$ \\
\hline Amer. Rest NS & & $\checkmark$ & Djibouti & $\checkmark$ & \\
\hline American Samoa & & $\checkmark$ & Djibouti Afars-Issas & & $\checkmark$ \\
\hline Angola & $\checkmark$ & $\checkmark$ & Dominica & $\checkmark$ & $\checkmark$ \\
\hline Anguilla & & $\checkmark$ & Dominican Republic & $\checkmark$ & $\checkmark$ \\
\hline Antigua and Barbuda & $\checkmark$ & $\checkmark$ & Ecuador & $\checkmark$ & $\checkmark$ \\
\hline Areas NES & & $\checkmark$ & Egypt & $\checkmark$ & $\checkmark$ \\
\hline Argentina & $\checkmark$ & $\checkmark$ & El Salvador & $\checkmark$ & $\checkmark$ \\
\hline Aruba & & $\checkmark$ & Equatorial Guinea & & $\checkmark$ \\
\hline Bahamas, The & $\checkmark$ & $\checkmark$ & Eritrea & $\checkmark$ & $\checkmark$ \\
\hline Bahrain & & $\checkmark$ & Ethiopia & $\checkmark$ & $\checkmark$ \\
\hline Bangladesh & $\checkmark$ & $\checkmark$ & Ethiopia PDR & $\checkmark$ & \\
\hline Barbados & $\checkmark$ & $\checkmark$ & Falkland Islands & & $\checkmark$ \\
\hline Belize & $\checkmark$ & $\checkmark$ & Fiji & & $\checkmark$ \\
\hline Benin & $\checkmark$ & $\checkmark$ & Fiji Islands & $\checkmark$ & \\
\hline Bermuda & $\checkmark$ & $\checkmark$ & Former Ethiopia & & $\checkmark$ \\
\hline Bhutan & & $\checkmark$ & Free Zones & & $\checkmark$ \\
\hline Bolivia & $\checkmark$ & $\checkmark$ & French Guiana & & $\checkmark$ \\
\hline Botswana & $\checkmark$ & & French Polynesia & $\checkmark$ & $\checkmark$ \\
\hline Brazil & $\checkmark$ & $\checkmark$ & French Southern \& Antarctic & & $\checkmark$ \\
\hline British Indian Ocean Territory & & $\checkmark$ & Gabon & $\checkmark$ & $\checkmark$ \\
\hline British Virgin Islands & & $\checkmark$ & Gambia, The & $\checkmark$ & $\checkmark$ \\
\hline Brunei & & $\checkmark$ & Ghana & $\checkmark$ & $\checkmark$ \\
\hline Brunei Darsm & $\checkmark$ & & Greenland & & $\checkmark$ \\
\hline Bunkers & & $\checkmark$ & Grenada & $\checkmark$ & $\checkmark$ \\
\hline Burkina & & $\checkmark$ & Guadeloupe & & $\checkmark$ \\
\hline Burkina Faso & $\checkmark$ & & Guatemala & $\checkmark$ & $\checkmark$ \\
\hline Burma & & $\checkmark$ & Guinea & $\checkmark$ & $\checkmark$ \\
\hline Burundi & $\checkmark$ & $\checkmark$ & Guinea-Bissau & $\checkmark$ & $\checkmark$ \\
\hline Cacm NES & & $\checkmark$ & Guyana & $\checkmark$ & $\checkmark$ \\
\hline Cambodia & $\checkmark$ & $\checkmark$ & Haiti & $\checkmark$ & $\checkmark$ \\
\hline Cameroon & $\checkmark$ & $\checkmark$ & Honduras & $\checkmark$ & $\checkmark$ \\
\hline Cape Verde & $\checkmark$ & $\checkmark$ & India & $\checkmark$ & $\checkmark$ \\
\hline Cayman Islands & & $\checkmark$ & Indonesia & $\checkmark$ & $\checkmark$ \\
\hline Central African Republic & $\checkmark$ & $\checkmark$ & Iran & $\checkmark$ & $\checkmark$ \\
\hline Chad & $\checkmark$ & $\checkmark$ & Iraq & $\checkmark$ & $\checkmark$ \\
\hline Chile & $\checkmark$ & $\checkmark$ & Jamaica & $\checkmark$ & $\checkmark$ \\
\hline China (Peoples Republic of) & $\checkmark$ & $\checkmark$ & Jordan & $\checkmark$ & $\checkmark$ \\
\hline Christmas Island & & & Kenya & $\checkmark$ & $\checkmark$ \\
\hline Cocos (Keeling) Islands & & $\checkmark$ & Kiribati & $\checkmark$ & $\checkmark$ \\
\hline Colombia & $\checkmark$ & $\checkmark$ & Korea, North & & $\checkmark$ \\
\hline Comoros & $\checkmark$ & $\checkmark$ & Korea Dem. Pples. Republic & $\checkmark$ & \\
\hline Congo, Democratic Republic & $\checkmark$ & & Korea, Republic of & $\checkmark$ & $\checkmark$ \\
\hline Congo, Rep & $\checkmark$ & & Kuwait & $\checkmark$ & $\checkmark$ \\
\hline Congo (Brazzaville) & & $\checkmark$ & Laia NES & & $\checkmark$ \\
\hline Cook Islands & & $\checkmark$ & Laos & $\checkmark$ & $\checkmark$ \\
\hline Costa Rica & $\checkmark$ & $\checkmark$ & Lebanon & $\checkmark$ & $\checkmark$ \\
\hline
\end{tabular}




\section{Appendix Table 1 Countries in Dataset (continued)}

\begin{tabular}{|c|c|c|c|c|c|}
\hline Region/Country & FAO & COMTRADE & Region/Country & FAO & COMTRADE \\
\hline \multicolumn{6}{|l|}{ Developing Countries } \\
\hline Lesotho & $\checkmark$ & & Saudi Arabia & $\checkmark$ & $\checkmark$ \\
\hline Liberia & $\checkmark$ & $\checkmark$ & Senegal & $\checkmark$ & $\checkmark$ \\
\hline Libya & $\checkmark$ & $\checkmark$ & Seychelles & $\checkmark$ & $\checkmark$ \\
\hline Madagascar & $\checkmark$ & $\checkmark$ & Sierra Leone & $\checkmark$ & $\checkmark$ \\
\hline Malawi & $\checkmark$ & $\checkmark$ & Solomon Islands & $\checkmark$ & $\checkmark$ \\
\hline Malaysia & $\checkmark$ & $\checkmark$ & Somalia & $\checkmark$ & $\checkmark$ \\
\hline Maldives & $\checkmark$ & & Spec Cats & & $\checkmark$ \\
\hline Maldive Islands & & $\checkmark$ & Sri Lanka & $\checkmark$ & $\checkmark$ \\
\hline Mali & $\checkmark$ & $\checkmark$ & St. Christopher-Nevis & $\checkmark$ & $\checkmark$ \\
\hline Marshal Islands & & $\checkmark$ & St. Helena (Brit. W. Af.) & & $\checkmark$ \\
\hline Martinique & & $\checkmark$ & St. Kitts Nev & $\checkmark$ & \\
\hline Mauritania & $\checkmark$ & $\checkmark$ & St. Lucia & $\checkmark$ & $\checkmark$ \\
\hline Mauritius & $\checkmark$ & $\checkmark$ & St. Pierre and Miquelon & & $\checkmark$ \\
\hline México & $\checkmark$ & $\checkmark$ & St. Vincent & $\checkmark$ & \\
\hline Micronesia, Federated State of & & $\checkmark$ & St. Vincent and Grenadines & & $\checkmark$ \\
\hline Mongolia & $\checkmark$ & $\checkmark$ & Sudan & $\checkmark$ & $\checkmark$ \\
\hline Montserrat & & $\checkmark$ & Suriname & $\checkmark$ & $\checkmark$ \\
\hline Morocco & $\checkmark$ & $\checkmark$ & Swaziland & $\checkmark$ & \\
\hline Mozambique & $\checkmark$ & $\checkmark$ & Syria & $\checkmark$ & $\checkmark$ \\
\hline Myanmar & $\checkmark$ & & Taiwan (Estimated) & & $\checkmark$ \\
\hline Namibia & $\checkmark$ & & Tanzania & $\checkmark$ & \\
\hline Nauru & & $\checkmark$ & Tanzania, United Rep. of & & $\checkmark$ \\
\hline Nepal & $\checkmark$ & $\checkmark$ & Thailand & $\checkmark$ & $\checkmark$ \\
\hline Netherlands Antilles & $\checkmark$ & $\checkmark$ & Togo & $\checkmark$ & $\checkmark$ \\
\hline New Caledonia & $\checkmark$ & $\checkmark$ & Tokelau & & $\checkmark$ \\
\hline Nicaragua & $\checkmark$ & $\checkmark$ & Tonga & & $\checkmark$ \\
\hline Niger & $\checkmark$ & $\checkmark$ & Trinidad and Tobago & $\checkmark$ & $\checkmark$ \\
\hline Nigeria & $\checkmark$ & $\checkmark$ & Trust Territory of Pac. Isles. & & $\checkmark$ \\
\hline Niue & & $\checkmark$ & Tunisia & $\checkmark$ & $\checkmark$ \\
\hline Northern Mariana Islands & & $\checkmark$ & Turkey & $\checkmark$ & $\checkmark$ \\
\hline Oceania NES & & $\checkmark$ & Turks and Caicos Islands & & $\checkmark$ \\
\hline Oman & & $\checkmark$ & Tuvalu & & $\checkmark$ \\
\hline Pakistan & $\checkmark$ & $\checkmark$ & Uganda & $\checkmark$ & $\checkmark$ \\
\hline Palau & & $\checkmark$ & United Arab Emirates & $\checkmark$ & $\checkmark$ \\
\hline Panamá & $\checkmark$ & $\checkmark$ & Uruguay & $\checkmark$ & $\checkmark$ \\
\hline Papua New Guinea & & $\checkmark$ & US Msc. Pac. Isles. & & $\checkmark$ \\
\hline Paraguay & $\checkmark$ & $\checkmark$ & Vanuatu & $\checkmark$ & \\
\hline Perú & $\checkmark$ & $\checkmark$ & Vanuatu/New Hebrides & & $\checkmark$ \\
\hline Philippines & $\checkmark$ & $\checkmark$ & Venezuela & $\checkmark$ & $\checkmark$ \\
\hline Pitcairn Islands & & $\checkmark$ & Vietnam & $\checkmark$ & $\checkmark$ \\
\hline Portuguese Timor & & $\checkmark$ & Yemen & $\checkmark$ & \\
\hline Qatar & & $\checkmark$ & Yemen (Sanaa) & & $\checkmark$ \\
\hline Reunion & & $\checkmark$ & Zaire & & $\checkmark$ \\
\hline Rwanda & $\checkmark$ & $\checkmark$ & Zambia & $\checkmark$ & $\checkmark$ \\
\hline Sao Tome and Principe & $\checkmark$ & $\checkmark$ & Zimbabwe & $\checkmark$ & $\checkmark$ \\
\hline
\end{tabular}

Source: FAOSTAT (2000) and United Nations Statistical Division, COMTRADE database (1999). 
Appendix Table 2 Products and Commodities

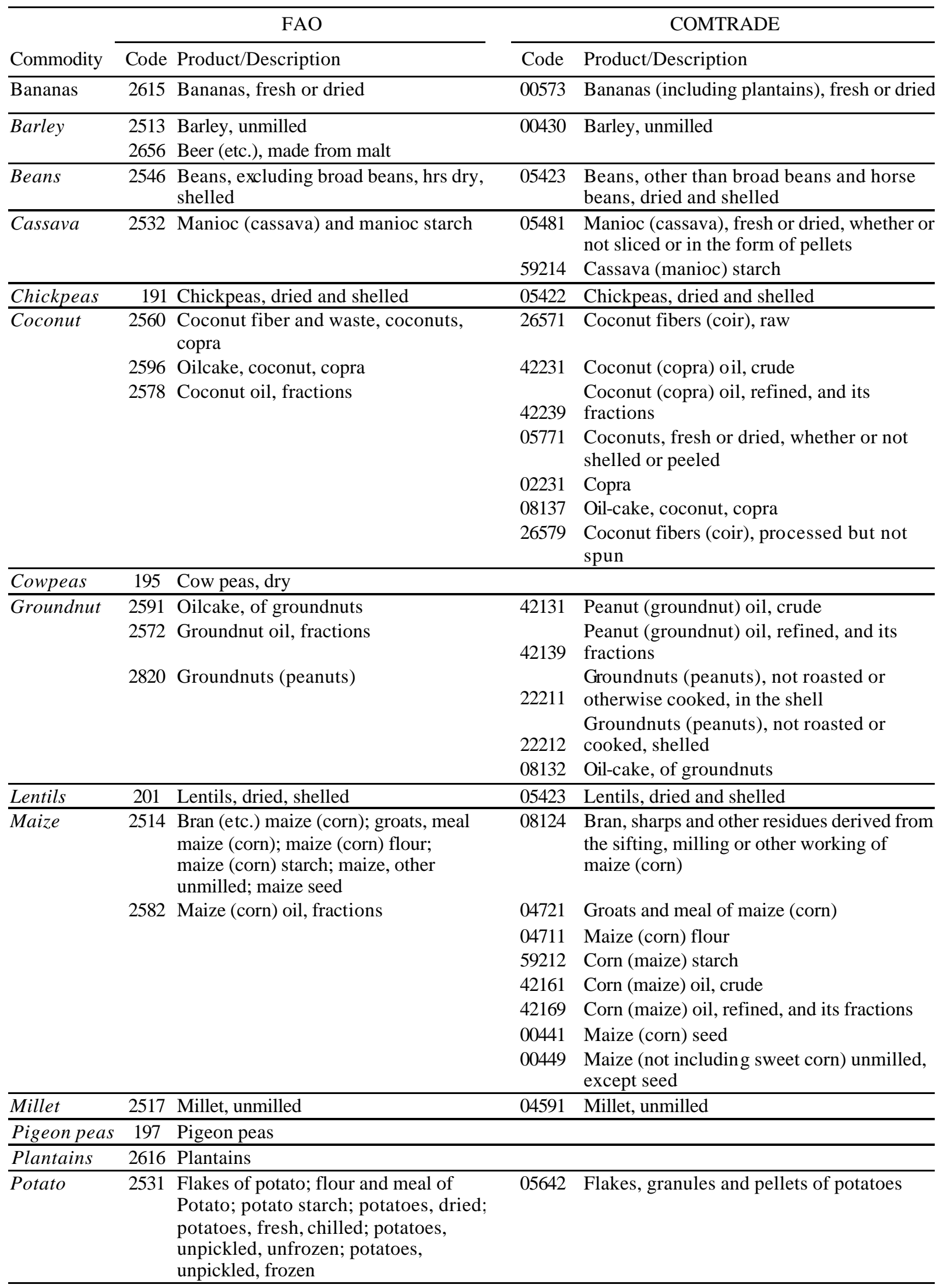




\section{Appendix Table 2 Products and Commodities (continued)}

\begin{tabular}{|c|c|c|c|c|}
\hline \multirow[b]{2}{*}{ Commodity } & \multicolumn{2}{|r|}{ FAO } & \multicolumn{2}{|r|}{ COMTRADE } \\
\hline & Code & Product/Description & Code & Product/Description \\
\hline \multirow{5}{*}{$\begin{array}{l}\text { Potatoes } \\
\text { (continued) }\end{array}$} & & & 05641 & Flour and meal of potatoes \\
\hline & & & 59213 & Potato starch \\
\hline & & & 05611 & $\begin{array}{l}\text { Potatoes, dried, whether or not cut or sliced, } \\
\text { but not further prepared }\end{array}$ \\
\hline & & & 00541 & $\begin{array}{l}\text { Potatoes, fresh or chilled (not including } \\
\text { sweet potatoes) }\end{array}$ \\
\hline & & & 05676 & $\begin{array}{l}\text { Potatoes, prepared or preserved otherwise } \\
\text { than by vinegar or acetic acid, not frozen }\end{array}$ \\
\hline \multirow[t]{3}{*}{ Rice } & & $\begin{array}{l}\text { Bran (etc.), rice; rice husked; rice in } \\
\text { the husk; rice, milled, semi milled }\end{array}$ & 08125 & $\begin{array}{l}\text { Bran, sharps and other residues derived from } \\
\text { the sifting, milling or other working of rice }\end{array}$ \\
\hline & 2581 & Rice bran oil & 00422 & $\begin{array}{l}\text { Rice husked but not further prepared (cargo } \\
\text { rice or brown rice husked); not further } \\
\text { prepared (cargo or brown rice) }\end{array}$ \\
\hline & & & 00421 & Rice in the husk (paddy or rough rice) \\
\hline Sorghum & 2518 & Grain sorghum, unmilled & 00453 & Grain sorghum, unmilled \\
\hline \multirow[t]{5}{*}{$\overline{\text { Soybeans }}$} & 2571 & Soya bean oil, fractions & 08131 & Oil \\
\hline & 2590 & Oilcake, of soya beans & 42111 & $\begin{array}{l}\text { Soybean oil, crude, whether or not } \\
\text { degummed }\end{array}$ \\
\hline & 2555 & Soya beans & 42119 & Soybean oil, refined, and its fractions \\
\hline & & & 02222 & Soybeans \\
\hline & & & 09841 & Soy sauce \\
\hline
\end{tabular}

\begin{tabular}{|c|c|c|c|c|}
\hline $\begin{array}{l}\text { Sweet } \\
\text { potatoes }\end{array}$ & 2533 & Sweet potatoes & & \\
\hline \multirow[t]{9}{*}{ Wheat } & 2511 & $\begin{array}{l}\text { Bran (etc) wheat; durum wheat, } \\
\text { unmilled; flour of wheat, meslin; } \\
\text { groats, meal, pellets, wheat; other } \\
\text { wheat, meslin, unmilled; pasta, } \\
\text { uncooked, unprepared; toasted bread } \\
\text { (etc); wheat gluten; } \\
\text { wheat starch }\end{array}$ & 08126 & $\begin{array}{l}\text { Bran, sharps and other residues derived from } \\
\text { the sifting, milling or other working of } \\
\text { wheat }\end{array}$ \\
\hline & & & 00411 & Durum wheat, unmilled \\
\hline & & & 00461 & Flour of wheat or of meslin \\
\hline & & & 00462 & Groats, meal and pellets, of wheat \\
\hline & & & 00412 & $\begin{array}{l}\text { Wheat (including spelt) and meslin, } \\
\text { unmilled }\end{array}$ \\
\hline & & & 00483 & $\begin{array}{l}\text { Macaroni, spaghetti and similar products } \\
\text { (pasta uncooked, not stuffed or otherwise } \\
\text { prepared) }\end{array}$ \\
\hline & & & 04841 & $\begin{array}{l}\text { Crispbread, rusks, toasted bread and similar } \\
\text { products }\end{array}$ \\
\hline & & & 59217 & Wheat gluten, dried or not \\
\hline & & & 59211 & Wheat starch \\
\hline
\end{tabular}

Source: United Nations Statistical Division COMTRADE database (1999). 
Appendix Table 3a Production of Cereals, 1997

\begin{tabular}{|c|c|c|c|c|c|c|c|c|c|c|c|c|}
\hline \multirow[b]{2}{*}{ Rank } & \multicolumn{2}{|l|}{ Rice } & \multicolumn{2}{|l|}{ Wheat } & \multicolumn{2}{|c|}{ Maize } & \multicolumn{2}{|c|}{ Barley } & \multicolumn{2}{|l|}{ Sorghum } & \multicolumn{2}{|l|}{ Millet } \\
\hline & Country & Share & Country & Share & Country & Share & Country & Share & Country & Share & Country & Share \\
\hline \multicolumn{13}{|c|}{ Developing Countries } \\
\hline 1 & China & 32.7 & China & 20.2 & China & 16.5 & Turkey & 5.3 & India & 14.3 & India & 37.3 \\
\hline 2 & India & 25.6 & India & 11.3 & Brazil & 5.6 & China & 2.6 & Nigeria & 11.6 & Nigeria & 20.9 \\
\hline 3 & Indonesia & 7.6 & Turkey & 3.1 & Mexico & 2.8 & Iran & 1.6 & Mexico & 9.1 & China & 8.9 \\
\hline 4 & Bangladesh & 4.4 & Pakistan & 2.7 & Argentina & 2.6 & India & 0.9 & China & 6.8 & Niger & 6.1 \\
\hline 7 & Myanmar & 3.4 & Egypt & $1 . \mathrm{C}$ & Nigeria & 0.8 & Ethiopia & 0.6 & Ethiopia & 3.2 & Burkina Faso & 2.1 \\
\hline 8 & Philippines & 1.7 & Mexico & 0.6 & Egypt & 0.8 & Argentina & 0.6 & Burkina Faso & 1.5 & Uganda & 1.8 \\
\hline 9 & Brazil & 1.6 & Syria & 0.5 & Philippines & 0.7 & Iraq & 0.5 & Egypt & 1.2 & Senegal & 1.5 \\
\hline 10 & Korea Rep & 1.2 & Afghanistan & 0.4 & Thailand & 0.6 & Mexico & 0.3 & Mali & 0.9 & Tanzania & 1.2 \\
\hline 1 & Japan & 2.8 & USA & 11.1 & USA & 41.7 & Canada & 8.7 & USA & 26.4 & USA & 0.6 \\
\hline 2 & USA & 1.3 & France & 5.5 & France & 2.8 & Germany & 8.7 & Australia & 2.3 & Australia & 0.1 \\
\hline 3 & Italy & 0.2 & Canada & $4 . \mathrm{C}$ & South Africa & 1.9 & France & 6.5 & France & 0.7 & South Africa & 0.0 \\
\hline 4 & Australia & 0.2 & Germany & 3.2 & Italy & 1.8 & Spain & 5.5 & South Africa & 0.7 & Spain & 0.0 \\
\hline 5 & Spain & 0.1 & Australia & 3.2 & Canada & 1.3 & USA & 5.3 & Italy & 0.3 & Japan & 0.0 \\
\hline 6 & Greece & 0.0 & UK & 2.5 & Spain & 0.8 & UK & 5.1 & Spain & 0.1 & & 0.0 \\
\hline 7 & Portugal & 0.0 & Italy & 1.1 & Germany & 0.6 & Australia & 4.2 & Greece & 0.0 & & 0.0 \\
\hline 8 & France & 0.0 & Denmark & 0.8 & Japan & 0.6 & Denmark & 2.5 & Israel & 0.0 & & 0.0 \\
\hline 9 & South Africa & 0.0 & Spain & 0.8 & Greece & 0.3 & Sweden & 1.3 & & 0.0 & & 0.0 \\
\hline 10 & & 0.0 & South Africa & 0.4 & Austria & 0.3 & Finland & 1.3 & & 0.0 & & 0.0 \\
\hline 3 & Kazakhstan & 0.0 & Kazakhstan & 1.5 & Yugoslavia & 1.1 & Poland & 2.5 & Russian Fed & 0.0 & Kazakhstan & 0.2 \\
\hline 4 & Ukraine & 0.0 & Poland & 1.3 & Ukraine & 0.9 & Kazakhstan & 1.7 & Hungary & 0.0 & Hungary & 0.0 \\
\hline 5 & Turkmenistan & 0.0 & Romania & 1.2 & Russian Fed & 0.4 & Czech Rep & 1.6 & Ukraine & 0.0 & Czech Rep & 0.0 \\
\hline 6 & Macedonia & 0.0 & Hungary & 0.9 & Croatia & 0.3 & Belarus & 1.5 & Yugoslavia & 0.0 & Uzbekistan & 0.0 \\
\hline 7 & Tajikistan & 0.0 & Czech Rep & 0.6 & Moldova Rep & 0.3 & Romania & 1.2 & Romania & 0.0 & Slovakia & 0.0 \\
\hline 8 & Hungary & 0.0 & Bulgaria & 0.6 & Bulgaria & 0.3 & Hungary & 0.9 & Croatia & 0.0 & Slovenia & 0.0 \\
\hline 9 & Kyrgyzstan & 0.0 & Uzbekistan & 0.5 & Slovakia & 0.1 & Lithuania & 0.8 & Moldova Rep & 0.0 & Moldova Rep & 0.0 \\
\hline 10 & Bulgaria & 0.0 & Yugoslavia & 0.5 & Georgia & 0.1 & Slovakia & 0.6 & Slovakia & 0.0 & Croatia & 0.0 \\
\hline & Top five & 0.2 & & 14.2 & & 5.5 & & 24.0 & & 0.1 & & 5.7 \\
\hline & Top ten & 0.2 & & 17.3 & & 6.6 & & 28.9 & & 0.1 & & 5.7 \\
\hline & All & 0.2 & & 19.1 & & 7.0 & & 30.9 & & 0.1 & & 5.7 \\
\hline World & $644,817,587^{l}$ & 100 & $610,545,794^{l}$ & 100 & $650,113,450^{l}$ & 100 & $154,984,272^{l}$ & 100 & $62,821,950^{l}$ & 100 & $28,187,121^{1}$ & 100 \\
\hline
\end{tabular}

Source: Compiled from FAOSTAT Database, Bulk FTP, using world average conversion factors (see table 1).

${ }^{1}$ Reported in metric tons. 
Appendix Table 3b Production of Roots, Tubers, Banana, and Plantain, 1997

\begin{tabular}{|c|c|c|c|c|c|c|c|c|c|c|c|c|}
\hline \multirow[b]{2}{*}{ Rank } & \multicolumn{2}{|l|}{ Cassava } & \multicolumn{2}{|l|}{ Potato } & \multicolumn{2}{|c|}{ Sweet Potato } & \multicolumn{2}{|l|}{ Yam } & \multicolumn{2}{|l|}{ Banana } & \multicolumn{2}{|l|}{ Plantain } \\
\hline & Country & Share & Country & Share & Country & Share & Country & Share & Country & Share & Country & Share \\
\hline \multicolumn{13}{|c|}{ Developing Countries } \\
\hline 1 & Nigeria & 18.4 & China & 16.5 & China & 86.1 & Nigeria & 64.4 & India & 17.4 & Uganda & 31.4 \\
\hline 2 & Brazil & 14.7 & India & 8.7 & Uganda & 1.5 & Côte d'Ivoire & 9.8 & Ecuador & 12.8 & Colombia & 8.8 \\
\hline 3 & Thailand & 11.0 & Turkey & 1.8 & Indonesia & 1.4 & Ghana & 7.9 & Brazil & 10.4 & Rwanda & 7.6 \\
\hline 4 & Congo, Dem R & 10.6 & Iran & 1.1 & Viet Nam & 1.3 & Benin & 4.6 & Philippines & 6.4 & Congo, Dem R & 6.4 \\
\hline 7 & India & 3.6 & Peru & 0.8 & Kenya & 0.6 & Congo, Dem R & 0.9 & Colombia & 3.8 & Côte d'Ivoire & 4.9 \\
\hline 8 & Tanzania & 3.5 & Argentina & 0.8 & Burundi & 0.5 & Ethiopia & 0.9 & Costa Rica & 3.8 & Peru & 4.5 \\
\hline 9 & Mozambique & 3.2 & Egypt & 0.6 & Tanzania & 0.5 & Haiti & 0.8 & Thailand & 2.9 & Cameroon & 3.5 \\
\hline 10 & China & 2.2 & Bangladesh & 0.5 & Brazil & 0.5 & Chad & 0.8 & Mexico & 2.9 & Tanzania & 3.1 \\
\hline 1 & & 0.0 & USA & 7.3 & Japan & 0.9 & Japan & 0.7 & Spain & 0.6 & & 0.0 \\
\hline 2 & & 0.0 & Germany & 4.2 & USA & 0.5 & Germany & 0.5 & Australia & 0.4 & & 0.0 \\
\hline 3 & & 0.0 & Netherlands & 2.8 & South Africa & 0.0 & Portugal & 0.0 & South Africa & 0.4 & & 0.0 \\
\hline 4 & & 0.0 & UK & 2.5 & New Zealand & 0.0 & & 0.0 & Israel & 0.2 & & 0.0 \\
\hline 5 & & 0.0 & France & 2.3 & Spain & 0.0 & & 0.0 & Portugal & 0.1 & & 0.0 \\
\hline 6 & & 0.0 & Canada & 1.4 & Portugal & 0.0 & & 0.0 & USA & 0.0 & & 0.0 \\
\hline 7 & & 0.0 & Japan & 1.2 & Italy & 0.0 & & 0.0 & Greece & 0.0 & & 0.0 \\
\hline 8 & & 0.0 & Spain & 1.1 & Israel & 0.0 & & 0.0 & Japan & 0.0 & & 0.0 \\
\hline 9 & & 0.0 & Italy & 0.7 & Australia & 0.0 & & 0.0 & Italy & 0.0 & & 0.0 \\
\hline 10 & & 0.0 & South Africa & 0.5 & Greece & 0.0 & & 0.0 & & 0.0 & & 0.0 \\
\hline 3 & & 0.0 & Ukraine & 5.8 & & 0.0 & & 0.0 & & 0.0 & Hungary & 0.0 \\
\hline 4 & & 0.0 & Belarus & 2.4 & & 0.0 & & 0.0 & & 0.0 & Czech Rep & 0.0 \\
\hline 5 & & 0.0 & Romania & 1.1 & & 0.0 & & 0.0 & & 0.0 & Slovakia & 0.0 \\
\hline 6 & & 0.0 & Lithuania & 0.6 & & 0.0 & & 0.0 & & 0.0 & Slovenia & 0.0 \\
\hline 7 & & 0.0 & Kazakhstan & 0.5 & & 0.0 & & 0.0 & & 0.0 & Moldova Rep & 0.0 \\
\hline 8 & & 0.0 & Czech Rep & 0.5 & & 0.0 & & 0.0 & & 0.0 & Croatia & 0.0 \\
\hline 9 & & 0.0 & Yugoslavia & 0.4 & & 0.0 & & 0.0 & & 0.0 & Macedonia & 0.0 \\
\hline 10 & & 0.0 & Hungary & 0.4 & & 0.0 & & 0.0 & & 0.0 & & 0.0 \\
\hline & Top five & 0.0 & & 29.3 & & 0.0 & & 0.0 & & 0.0 & & 4.4 \\
\hline & Top ten & 0.0 & & 31.6 & & 0.0 & & 0.0 & & 0.0 & & 4.4 \\
\hline & All & 0.0 & & 34.0 & & 0.0 & & 0.0 & & 0.0 & & 0.0 \\
\hline World & $164,908,774^{1}$ & 100 & $610,545,794^{l}$ & 100 & $650,113,450^{1}$ & 100 & $154,984,272^{l}$ & 100 & $58,561,777^{l}$ & 100 & $29,629,425^{1}$ & $\overline{100}$ \\
\hline
\end{tabular}

Source: Compiled from FAOSTAT Database, Bulk FTP, using world average conversion factors (see table 1).

${ }^{1}$ Reported in metric tons. 
Appendix Table 3c Production of Food Legumes, 1997

\begin{tabular}{|c|c|c|c|c|c|c|c|c|c|c|c|c|}
\hline \multirow[b]{2}{*}{ Rank } & \multicolumn{2}{|l|}{ Chickpeas } & \multicolumn{2}{|l|}{ Cowpeas } & \multicolumn{2}{|l|}{ Beans } & \multicolumn{2}{|l|}{ Lentil } & \multicolumn{2}{|c|}{ Pigeon peas } & \multicolumn{2}{|c|}{ Soybeans } \\
\hline & Country & Share & Country & Share & Country & Share & Country & Share & Country & Share & Country & Share \\
\hline \multicolumn{13}{|c|}{ Developing Countries } \\
\hline 2 & Turkey & 8.6 & Niger & 18.5 & Brazil & 17.7 & Turkey & 18.8 & Myanmar & 5.7 & China & 9.6 \\
\hline 3 & Pakistan & 7.1 & Myanmar & 2.4 & China & 7.7 & Bangladesh & 6.2 & Malawi & 3.4 & Argentina & 8.7 \\
\hline 4 & Iran & 3.2 & Malawi & 2.2 & Mexico & 5.7 & Iran & 4.7 & Uganda & 2.1 & India & 4.0 \\
\hline 7 & Myanmar & 1.1 & Tanzania & 1.7 & Burundi & 1.6 & Syria & 3.2 & Dominican $\mathrm{Rp}$ & 0.5 & Bolivia & 0.7 \\
\hline 8 & Bangladesh & 0.7 & Haiti & 1.4 & Korea D P Rp & 1.6 & Ethiopia & 1.3 & Venezuela & 0.1 & Korea Rep & 0.6 \\
\hline 9 & Syria & 0.7 & Senegal & 1.4 & Argentina & 1.6 & Pakistan & 1.3 & Trinidad Tob & 0.1 & Thailand & 0.5 \\
\hline 10 & Morocco & 0.5 & Mauritania & 0.9 & Turkey & 1.4 & Morocco & 1.0 & Haiti & 0.1 & Indonesia & 0.4 \\
\hline 1 & Australia & 2.3 & South Africa & 0.2 & USA & 7.8 & Canada & 13.8 & & 0.0 & USA & 41.1 \\
\hline 2 & Spain & 0.8 & USA & 0.1 & Canada & 0.9 & USA & 4.0 & & 0.0 & Netherlands & 2.2 \\
\hline 3 & Portugal & 0.1 & Australia & 0.1 & Japan & 0.6 & Australia & 1.3 & & 0.0 & Japan & 2.1 \\
\hline 4 & Israel & 0.1 & Japan & 0.0 & South Africa & 0.4 & Spain & 0.8 & & 0.0 & Germany & 1.9 \\
\hline 5 & Italy & 0.0 & & 0.0 & Australia & 0.2 & France & 0.2 & & 0.0 & Canada & 1.6 \\
\hline 6 & Greece & 0.0 & & 0.0 & Spain & 0.2 & New Zealand & 0.1 & & 0.0 & Spain & 1.3 \\
\hline 7 & & 0.0 & & 0.0 & Greece & 0.1 & Greece & 0.0 & & 0.0 & Italy & 1.0 \\
\hline 8 & & 0.0 & & 0.0 & Italy & 0.1 & Italy & 0.0 & & 0.0 & UK & 0.4 \\
\hline 9 & & 0.0 & & 0.0 & Ireland & 0.1 & Israel & 0.0 & & 0.0 & France & 0.3 \\
\hline 10 & & & & 0.0 & Portugal & 0.1 & & & & 0.0 & Portugal & 0.3 \\
\hline 3 & Macedonia & 0.0 & Bosnia Herzg & 0.1 & Romania & 0.3 & Slovakia & 0.1 & & 0.0 & Romania & 0.1 \\
\hline 4 & Bosnia Herzg & 0.0 & Croatia & 0.0 & Ukraine & 0.3 & Hungary & 0.0 & & 0.0 & Croatia & 0.1 \\
\hline 5 & & 0.0 & Slovenia & 0.0 & Poland & 0.3 & Tajikistan & 0.0 & & 0.0 & Poland & 0.0 \\
\hline 6 & & 0.0 & & 0.0 & Moldova Rep & 0.2 & Azerbaijan & 0.0 & & 0.0 & Hungary & 0.0 \\
\hline 7 & & 0.0 & & 0.0 & Bulgaria & 0.1 & Slovenia & 0.0 & & 0.0 & Bulgaria & 0.0 \\
\hline 8 & & 0.0 & & 0.0 & Croatia & 0.1 & Macedonia & 0.0 & & 0.0 & Uzbekistan & 0.0 \\
\hline 9 & & 0.0 & & 0.0 & Albania & 0.1 & Croatia & 0.0 & & 0.0 & Ukraine & 0.0 \\
\hline 10 & & 0.0 & & 0.0 & Macedonia & 0.1 & Bosnia Herzg & 0.0 & & 0.0 & Czech Rep & 0.0 \\
\hline & Top five & 0.1 & & 1.5 & & 2.4 & & 0.3 & & 0.0 & & 0.4 \\
\hline & Top ten & 0.1 & & 1.5 & & 3.1 & & 0.3 & & 0.0 & & 0.5 \\
\hline & All & 0.1 & & 1.5 & & 3.3 & & 0.3 & & 0.0 & & 0.5 \\
\hline World & $8,388,650^{l}$ & 0 & $610,545,794^{1}$ & 100 & $650,113,450^{l}$ & 100 & $154,984,272^{l}$ & 100 & $2,865,901^{I}$ & 100 & $369,961,368^{l}$ & $\overline{100}$ \\
\hline
\end{tabular}

Source: Compiled from FAOSTAT Database, Bulk FTP, using world average conversion factors (see table 1).

${ }^{1}$ Reported in metric tons. 


\section{Appendix Table 3d Production of Oil Crops, 1997}

\begin{tabular}{|c|c|c|c|c|}
\hline \multirow[b]{2}{*}{ Rank } & \multicolumn{2}{|l|}{ Groundnut } & \multicolumn{2}{|l|}{ Coconut } \\
\hline & Country & Share & Country & Share \\
\hline \multicolumn{5}{|c|}{ Developing Countries } \\
\hline 1 & China & 32.3 & Philippines & 33.1 \\
\hline 2 & India & 31.1 & Indonesia & 27.2 \\
\hline 3 & Nigeria & 9.9 & India & 16.2 \\
\hline 4 & Sudan & 2.9 & Viet Nam & 3.3 \\
\hline 5 & Myanmar & 2.3 & Mexico & 3.1 \\
\hline 6 & Senegal & 2.0 & Sri Lanka & 2.5 \\
\hline 7 & Indonesia & 1.8 & Thailand & 2.4 \\
\hline 8 & Argentina & 1.3 & Papua N Guin & 1.2 \\
\hline 9 & Congo, Dem R & 1.1 & Malaysia & 1.2 \\
\hline \multirow[t]{4}{*}{10} & Chad & 0.9 & Mozambique & 1.1 \\
\hline & Top five & 78.4 & & 83.0 \\
\hline & Top ten & 85.5 & & 91.2 \\
\hline & All & 94.9 & & 98.4 \\
\hline \multicolumn{5}{|c|}{ Developed Countries } \\
\hline 1 & USA & 3.6 & Germany & 0.9 \\
\hline 2 & South Africa & 0.5 & Japan & 0.4 \\
\hline 3 & Netherlands & 0.4 & Ireland & 0.2 \\
\hline 4 & France & 0.1 & UK & 0.1 \\
\hline 5 & Australia & 0.1 & Sweden & 0.0 \\
\hline 6 & Japan & 0.1 & China, H.Kong & 0.0 \\
\hline 7 & Greece & 0.0 & New Zealand & 0.0 \\
\hline 8 & Italy & 0.0 & Spain & 0.0 \\
\hline 9 & Israel & 0.0 & Denmark & 0.0 \\
\hline \multirow[t]{4}{*}{10} & Portugal & 0.0 & & 0.0 \\
\hline & Top five & 4.6 & & 1.6 \\
\hline & Top ten & 4.8 & & 1.6 \\
\hline & All & 4.9 & & 1.6 \\
\hline \multicolumn{5}{|c|}{ Transition Economies } \\
\hline 1 & Czech Rep & 0.1 & Poland & 0.0 \\
\hline 2 & Uzbekistan & 0.1 & & 0.0 \\
\hline 3 & Bulgaria & 0.0 & & 0.0 \\
\hline 4 & Poland & 0.0 & & 0.0 \\
\hline 5 & Slovakia & 0.0 & & 0.0 \\
\hline 6 & Yugoslavia & 0.0 & & 0.0 \\
\hline 7 & Kazakhstan & 0.0 & & 0.0 \\
\hline 8 & Georgia & 0.0 & & 0.0 \\
\hline 9 & & 0.0 & & 0.0 \\
\hline 10 & & 0.0 & & 0.0 \\
\hline & Top five & 0.2 & & 0.0 \\
\hline & Top ten & 0.2 & & 0.0 \\
\hline & All & 0.2 & & 0.0 \\
\hline World & $63,701,898^{l}$ & 100 & $610,545,794^{1}$ & 100 \\
\hline
\end{tabular}

Source: Compiled from FAOSTAT Database, Bulk FTP, using world average conversion factors (see table 1).

${ }^{1}$ Reported in metric tons. 


\section{Appendix Table 4a Soybean Exports by Developing Countries, 1994-98 Annual Average}

\begin{tabular}{|c|c|c|c|c|c|c|c|}
\hline \multicolumn{4}{|c|}{ A. Country to country (top 20) } & \multicolumn{4}{|c|}{ B. Country to region (top20) } \\
\hline Origin & Destination & Value & Share & Origin & Destination & Value & Share \\
\hline & & $(1,000$ US\$) & $\%$ & & & $(1,000$ US\$) & $\%$ \\
\hline Brazil & France & 694,516 & 13.50 & Brazil & Developed & $3,044,148$ & 59.16 \\
\hline Brazil & Netherlands, The & 433,358 & 8.42 & Argentina & Developed & $1,501,520$ & 29.18 \\
\hline Brazil & Spain & 399,448 & 7.76 & Paraguay & Developed & 219,284 & 4.26 \\
\hline Brazil & Germany & 398,274 & 7.74 & China (PRC) & Developed & 187,176 & 3.64 \\
\hline Argentina & Italy & 298,215 & 5.80 & India & Developed & 61,490 & 1.19 \\
\hline Brazil & Italy & 220,791 & 4.29 & Malaysia & Developed & 47,043 & 0.91 \\
\hline Argentina & Netherlands, The & 218,000 & 4.24 & Taiwan (estimated) & Developed & 14,560 & 0.28 \\
\hline Brazil & Japan & 214,666 & 4.17 & Areas NES & Developed & 11,170 & 0.22 \\
\hline Argentina & Spain & 200,477 & 3.90 & Uruguay & Developed & 10,737 & 0.21 \\
\hline Argentina & Germany & 179,545 & 3.49 & Bolivia & Developed & 9,365 & 0.18 \\
\hline Brazil & Belgium & 164,946 & 3.21 & Mexico & Developed & 8,232 & 0.16 \\
\hline Brazil & United Kingdom & 153,521 & 2.98 & Korea, Republic of & Developed & 5,907 & 0.11 \\
\hline Argentina & Denmark & 139,086 & 2.70 & Indonesia & Developed & 4,429 & 0.09 \\
\hline Argentina & Belgium & 124,401 & 2.42 & Thailand & Developed & 3,553 & 0.07 \\
\hline Brazil & Denmark & 120,167 & 2.34 & Zimbabwe & Developed & 2,415 & 0.05 \\
\hline Brazil & Portugal & 107,354 & 2.09 & Philippines, The & Developed & 1,890 & 0.04 \\
\hline China (PRC) & Japan & 94,844 & 1.84 & Zambia & Developed & 1,872 & 0.04 \\
\hline Paraguay & Netherlands, The & 90,443 & 1.76 & Chile & Developed & 1,850 & 0.04 \\
\hline China (PRC) & Hong Kong & 74,070 & 1.44 & Trinidad and Tobago & Developed & 1,593 & 0.03 \\
\hline Argentina & France & 70,024 & 1.36 & Algeria & Developed & 1,099 & 0.02 \\
\hline \multirow[t]{12}{*}{ Total } & & $4,396,149$ & 85.43 & Total & & $5,139,331$ & 99.88 \\
\hline & & & & \multicolumn{4}{|c|}{ C. Subregion to region (total) } \\
\hline & & & & Origin & Destination & Value & Share \\
\hline & & & & & & $(1,000$ US\$) & $\%$ \\
\hline & & & & Developing & Western Europe & $4,367,714$ & 84.88 \\
\hline & & & & Developing & Eastern Asia ${ }^{1}$ & 596,874 & 11.60 \\
\hline & & & & Developing & Southern Africa & 49,025 & 0.95 \\
\hline & & & & Developing & Southeast Asia & 50,520 & 0.98 \\
\hline & & & & Developing & North America & 48,142 & 0.94 \\
\hline & & & & Developing & Australia/NZ & 25,754 & 0.50 \\
\hline & & & & Developing & West Asia & 7,686 & 0.15 \\
\hline & & & & Total & & $5,145,714$ & 100 \\
\hline
\end{tabular}

Source: Compiled from United Nations Statistical Division, COMTRADE database (1999).

${ }^{1}$ Includes Japan, Hong Kong, and Macau. 


\section{Appendix Table 4b: Banana Exports by Developing Countries, 1994-98 Annual Average}

A. Country to country (top 20)

\begin{tabular}{lllrc} 
& Origin & Destination & \multicolumn{1}{c}{ Value } & Share \\
\cline { 2 - 5 } 1 & Costa Rica & United States & 361,840 & 7.78 \\
2 & Ecuador & United States & 347,154 & 7.46 \\
3 & Philippines, The & Japan & 305,293 & 6.56 \\
4 & Ecuador & Germany & 220,137 & 4.73 \\
5 & Colombia & United States & 204,345 & 4.39 \\
6 & Panama & Germany & 188,669 & 4.06 \\
7 & Guatemala & United States & 181,791 & 3.91 \\
8 & Honduras & United States & 180,406 & 3.88 \\
9 & Costa Rica & Germany & 170,734 & 3.67 \\
10 & Colombia & Germany & 156,224 & 3.36 \\
11 & Cote d'Ivoire & France & 96,167 & 2.07 \\
12 & Cameroon & France & 93,875 & 2.02 \\
13 & Colombia & Belgium & 88,784 & 1.91 \\
14 & Costa Rica & Belgium & 86,056 & 1.85 \\
15 & Ecuador & Italy & 85,973 & 1.85 \\
16 & Ecuador & Japan & 76,633 & 1.65 \\
17 & Ecuador & Belgium & 73,213 & 1.57 \\
18 & Mexico & United States & 67,387 & 1.45 \\
19 & St. Lucia & United Kingdom & 63,678 & 1.37 \\
20 & Jamaica & United Kingdom & 63,495 & 1.37 \\
& Total & & $3,111,853$ & 66.90 \\
\hline
\end{tabular}

B. Country to region (top20)

\begin{tabular}{|c|c|c|c|}
\hline Origin & Destination & Value & Share \\
\hline & & $(1,000$ US\$) & $\%$ \\
\hline Ecuador & Developed & 974,634 & 20.95 \\
\hline Costa Rica & Developed & 957,633 & 20.59 \\
\hline Colombia & Developed & 666,268 & 14.32 \\
\hline Panama & Developed & 440,780 & 9.48 \\
\hline Philippines, The & Developed & 320,658 & 6.89 \\
\hline Honduras & Developed & 240,460 & 5.17 \\
\hline Guatemala & Developed & 220,608 & 4.74 \\
\hline Cameroon & Developed & 128,069 & 2.75 \\
\hline Cote d'Ivoire & Developed & 123,920 & 2.66 \\
\hline Mexico & Developed & 75,337 & 1.62 \\
\hline St. Lucia & Developed & 64,868 & 1.39 \\
\hline Jamaica & Developed & 63,698 & 1.37 \\
\hline Taiwan (estimated) & Developed & 48,361 & 1.04 \\
\hline Martinique & Developed & 46,971 & 1.01 \\
\hline Dominican Republic & Developed & 45,176 & 0.97 \\
\hline Belize & Developed & 32,728 & 0.70 \\
\hline Venezuela & Developed & 30,828 & 0.66 \\
\hline St.Vincent/Grenadines & Developed & 28,700 & 0.62 \\
\hline Dominica & Developed & 26,518 & 0.57 \\
\hline Surinam & Developed & 23,694 & 0.51 \\
\hline Total & & $4,559,908$ & 98.03 \\
\hline \multicolumn{4}{|c|}{ C. Subregion to region (total) } \\
\hline \multirow[t]{2}{*}{ Origin } & Destination & Value & Share \\
\hline & & $(1,000$ US\$) & $\%$ \\
\hline Developing & Western Europe & $2,576,637$ & 55.39 \\
\hline Developing & North America & $1,601,175$ & 34.42 \\
\hline Developing & Eastern Asia ${ }^{1}$ & 462,781 & 9.95 \\
\hline Developing & Southeast Asia & 10,403 & 0.22 \\
\hline Developing & Southern Africa & 407 & 0.01 \\
\hline Developing & Australia/NZ & 25 & 0.00 \\
\hline Developing & West Asia & 6 & 0.00 \\
\hline Total & & $4,651,434$ & 100 \\
\hline
\end{tabular}

Source: Compiled from United Nations Statistical Division, COMTRADE database (1999).

${ }^{1}$ Includes Japan, Hong Kong, and Macau. 


\section{Appendix Table 4c Rice Exports by Developing Countries, 1994-98 Annual Average}

\begin{tabular}{|c|c|c|c|}
\hline Origin & Destination & Value & Share \\
\hline & & $(1,000$ US\$) & $\%$ \\
\hline Thailand & Hong Kong & 138,505 & 11.15 \\
\hline China (PRC) & Japan & 130,816 & 10.53 \\
\hline Thailand & United States & 129,059 & 10.39 \\
\hline Thailand & Singapore & 113,186 & 9.11 \\
\hline Thailand & Japan & 109,648 & 8.83 \\
\hline Thailand & S.Afr.Cus.Un & 71,291 & 5.74 \\
\hline India & United Kingdom & 58,717 & 4.73 \\
\hline Thailand & France & 51,902 & 4.18 \\
\hline Netherlands Antilles & Netherlands, The & 44,946 & 3.62 \\
\hline India & United States & 30,564 & 2.46 \\
\hline Thailand & Canada & 26,008 & 2.09 \\
\hline India & S.Afr.Cus.Un & 24,563 & 1.98 \\
\hline Netherlands Antilles & Portugal & 22,065 & 1.78 \\
\hline India & France & 22,022 & 1.77 \\
\hline Thailand & Israel & 15,927 & 1.28 \\
\hline Thailand & Australia & 14,452 & 1.16 \\
\hline Thailand & Italy & 11,875 & 0.96 \\
\hline Netherlands Antilles & Germany & 10,278 & 0.83 \\
\hline Aruba & Netherlands, The & 10,043 & 0.81 \\
\hline Thailand & Germany & 9,469 & 0.76 \\
\hline Total & & $1,045,335$ & 84.16 \\
\hline
\end{tabular}

B. Country to region (top20)

\begin{tabular}{|c|c|c|c|}
\hline Origin & Destination & Value & Share \\
\hline & & (1,000 US\$) & $\%$ \\
\hline Thailand & Developed & 728,786 & 58.68 \\
\hline India & Developed & 164,644 & 13.26 \\
\hline China (PRC) & Developed & 142,723 & 11.49 \\
\hline Netherlands Antilles & Developed & 92,976 & 7.49 \\
\hline Pakistan & Developed & 21,583 & 1.74 \\
\hline Guyana & Developed & 17,419 & 1.40 \\
\hline Surinam & Developed & 17,357 & 1.40 \\
\hline Vietnam & Developed & 17,345 & 1.40 \\
\hline Aruba & Developed & 11,625 & 0.94 \\
\hline Montserrat & Developed & 6,312 & 0.51 \\
\hline Uruguay & Developed & 2,846 & 0.23 \\
\hline Egypt & Developed & 2,404 & 0.19 \\
\hline Areas NES & Developed & 2,281 & 0.18 \\
\hline Turks/Caicos Isles & Developed & 1,709 & 0.14 \\
\hline French Guiana & Developed & 1,636 & 0.13 \\
\hline Burma & Developed & 1,513 & 0.12 \\
\hline Brazil & Developed & 1,207 & 0.10 \\
\hline Argentina & Developed & 1,047 & 0.08 \\
\hline Sri Lanka & Developed & 695 & 0.06 \\
\hline Madagascar & Developed & 634 & 0.05 \\
\hline Total & & $1,236,743$ & 99.57 \\
\hline \multicolumn{4}{|c|}{ C. Subregion to region (total) } \\
\hline \multirow[t]{2}{*}{ Origin } & Destination & Value & Share \\
\hline & & $(1,000$ US\$) & $\%$ \\
\hline Developing & Western Europe & 394,174 & 31.74 \\
\hline Developing & Eastern Asia ${ }^{1}$ & 395,493 & 31.84 \\
\hline Developing & North America & 210,338 & 16.93 \\
\hline Developing & Southeast Asia & 123,713 & 9.96 \\
\hline Developing & Southern Africa & 78,827 & 6.35 \\
\hline Developing & Australia/NZ & 20,743 & 1.67 \\
\hline Developing & West Asia & 18,776 & 1.51 \\
\hline Total & & $1,242,062$ & 100 \\
\hline
\end{tabular}

Source: Compiled from United Nations Statistical Division, COMTRADE database (1999).

${ }^{1}$ Includes Japan, Hong Kong, and Macau. 


\section{Appendix Table 4d: Coconut Exports by Developing Countries, 1994-98 Annual Average}

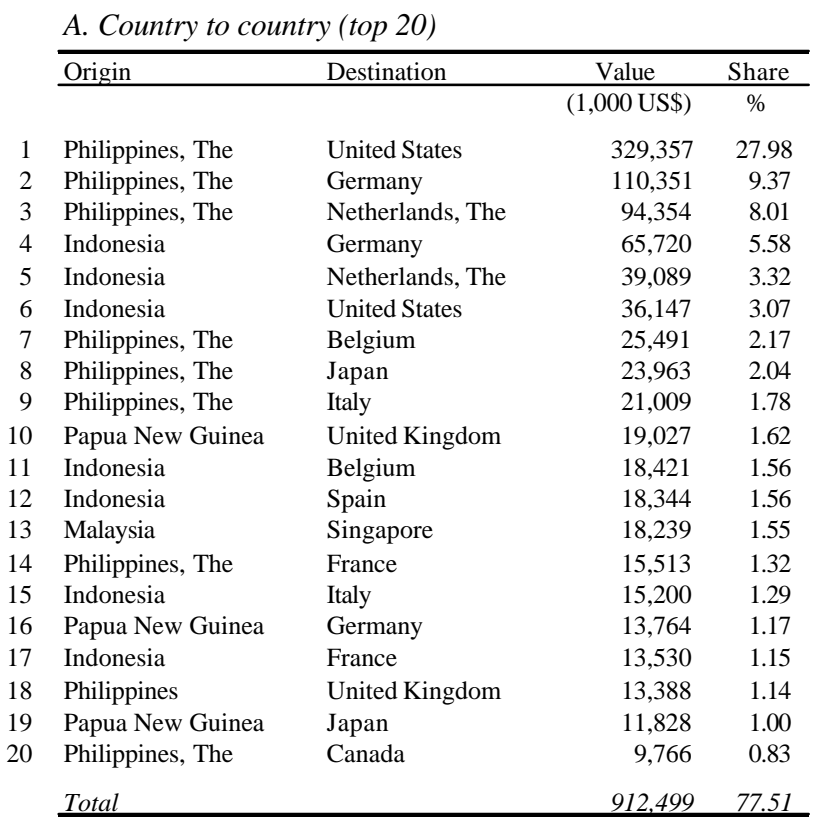

B. Country to region (top20)

\begin{tabular}{lcrr}
\hline Origin & Destination & \multicolumn{1}{c}{ Value } & Share \\
\hline & & $(1,000$ US $\$)$ & \multicolumn{1}{c}{$\%$} \\
Philippines, The & Developed & 683,466 & 58.06 \\
Indonesia & Developed & 250,972 & 21.32 \\
Papua New Guinea & Developed & 55,788 & 4.74 \\
Sri Lanka & Developed & 47,823 & 4.06 \\
Malaysia & Developed & 39,193 & 3.33 \\
Cote d'Ivoire & Developed & 24,851 & 2.11 \\
Vanuatu/New Hebrides & Developed & 10,788 & 0.92 \\
Dominican Republic & Developed & 10,574 & 0.90 \\
Solomon Islands & Developed & 9,030 & 0.77 \\
Thailand & Developed & 8,492 & 0.72 \\
Mozambique & Developed & 6,464 & 0.55 \\
French Polynesia & Developed & 4,845 & 0.41 \\
American Samoa & Developed & 4,619 & 0.39 \\
Fiji & Developed & 3,633 & 0.31 \\
India & Developed & 2,512 & 0.21 \\
Marshal Islands & Developed & 2,358 & 0.20 \\
Mexico & Developed & 1,797 & 0.15 \\
Areas NES & Developed & 1,749 & 0.15 \\
Brazil & Developed & 1,406 & 0.12 \\
Argentina & Developed & 1,013 & 0.09 \\
Total & & $1,171,373$ & 99.50 \\
\hline
\end{tabular}

C. Subregion to region (total)

\begin{tabular}{llrc}
\hline Origin & Destination & \multicolumn{1}{c}{ Value } & Share \\
\hline & & $(1,000$ US\$ $)$ & \multicolumn{1}{c}{$\%$} \\
Developing & Western Europe & 661,028 & 56.15 \\
Developing & North America & 402,726 & 34.21 \\
Developing & Eastern Asia ${ }^{1}$ & 56,031 & 4.76 \\
Developing & Australia/NZ & 26,818 & 2.28 \\
Developing & Southeast Asia & 23,420 & 1.99 \\
Developing & Southern Africa & 5,537 & 0.47 \\
Developing & West Asia & 1,697 & 0.14 \\
Total & & $1,177,257$ & 100 \\
\hline
\end{tabular}

Source: Compiled from United Nations Statistical Division, COMTRADE database (1999).

${ }^{1}$ Includes Japan, Hong Kong, and Macau. 


\section{Appendix Table 4e: Groundnut Exports by Developing Countries, 1994-98 Annual Average}

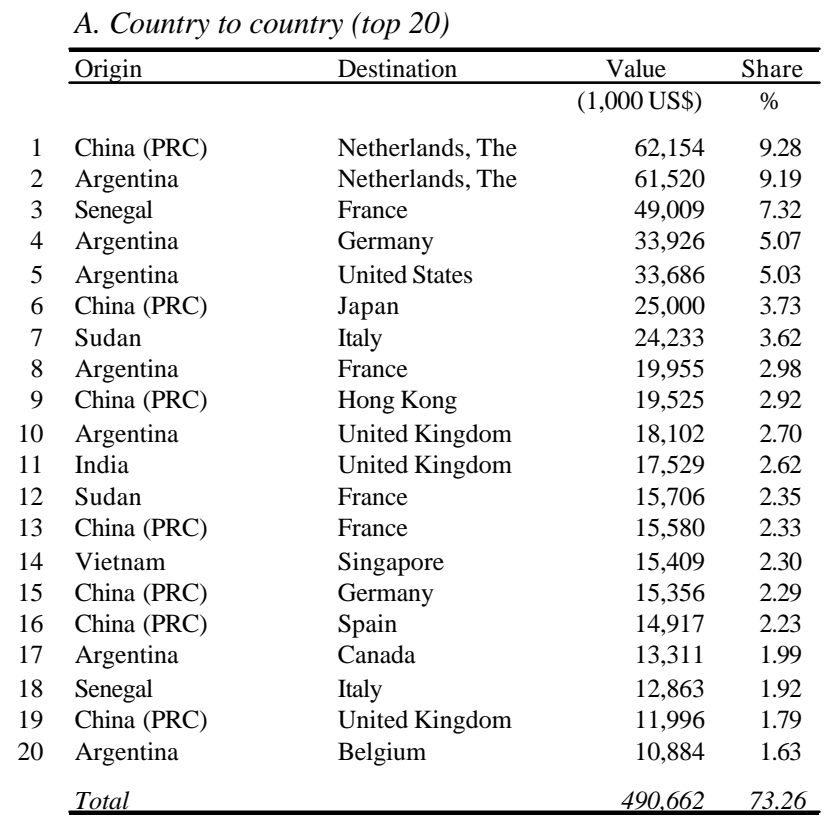

B. Country to region (top20)

\begin{tabular}{|c|c|c|c|}
\hline Origin & Destination & Value & Share \\
\hline & & $(1,000$ US\$) & $\%$ \\
\hline Argentina & Developed & 227,653 & 33.99 \\
\hline China (PRC) & Developed & 209,950 & 31.35 \\
\hline Senegal & Developed & 81,723 & 12.20 \\
\hline Sudan & Developed & 48,962 & 7.31 \\
\hline India & Developed & 35,883 & 5.36 \\
\hline Vietnam & Developed & 16,213 & 2.42 \\
\hline Brazil & Developed & 10,003 & 1.49 \\
\hline Nigeria & Developed & 8,487 & 1.27 \\
\hline Gambia, The & Developed & 6,856 & 1.02 \\
\hline Nicaragua & Developed & 5,745 & 0.86 \\
\hline Egypt & Developed & 5,131 & 0.77 \\
\hline Mexico & Developed & 3,533 & 0.53 \\
\hline Paraguay & Developed & 1,369 & 0.20 \\
\hline Saudi Arabia & Developed & 998 & 0.15 \\
\hline Zimbabwe & Developed & 863 & 0.13 \\
\hline Uruguay & Developed & 769 & 0.11 \\
\hline Malaysia & Developed & 700 & 0.10 \\
\hline Chad & Developed & 629 & 0.09 \\
\hline Antigua and Barbuda & Developed & 547 & 0.08 \\
\hline Indonesia & Developed & 390 & 0.06 \\
\hline Total & & 666,405 & 99.50 \\
\hline \multicolumn{4}{|c|}{ C. Subregion to region (total) } \\
\hline \multirow[t]{2}{*}{ Origin } & Destination & Value & Share \\
\hline & & $(1,000$ US\$) & $\%$ \\
\hline Developing & Western Europe & 498,319 & 74.40 \\
\hline Developing & North America & 64,733 & 9.67 \\
\hline Developing & Eastern Asia $^{1}$ & 53,390 & 7.97 \\
\hline Developing & Southeast Asia & 34,055 & 5.08 \\
\hline Developing & Australia/NZ & 9,964 & 1.49 \\
\hline Developing & Southern Africa & 9,080 & 1.36 \\
\hline Developing & West Asia & 200 & 0.03 \\
\hline Total & & 669,741 & 100 \\
\hline
\end{tabular}

Source: Compiled from United Nations Statistical Division, COMTRADE database (1999).

${ }^{1}$ Includes Japan, Hong Kong, and Macau. 


\section{Appendix Table 4f Wheat Exports by Developing Countries, 1994-98 Annual Average}

A. Country to country (top 20)

\begin{tabular}{llrr}
\hline Origin & Destination & \multicolumn{1}{c}{ Value } & Share \\
\hline & & $(1,000$ US\$) & $\%$ \\
Mexico & United States & 83,465 & 13.91 \\
China (PRC) & Hong Kong & 68,745 & 11.46 \\
Malaysia & Singapore & 37,375 & 6.23 \\
Thailand & Japan & 33,976 & 5.66 \\
China (PRC) & Japan & 25,854 & 4.31 \\
Mexico & Italy & 21,856 & 3.64 \\
China (PRC) & United States & 20,305 & 3.38 \\
Korea, Republic of & United States & 19,636 & 3.27 \\
Taiwan (estimated) & United States & 17,304 & 2.88 \\
Thailand & United States & 16,160 & 2.69 \\
Indonesia & Japan & 15,924 & 2.65 \\
Malaysia & Hong Kong & 8,120 & 1.35 \\
Korea, Republic of & Hong Kong & 8,066 & 1.34 \\
Turkey & United States & 7,520 & 1.25 \\
Spec Cats & Germany & 7,255 & 1.21 \\
Taiwan (estimated) & Japan & 6,306 & 1.05 \\
Taiwan (estimated) & Hong Kong & 6,239 & 1.04 \\
Turkey & Italy & 5,942 & 0.99 \\
China (PRC) & Singapore & 5,522 & 0.92 \\
Philippines & United States & 4,913 & 0.82 \\
Total & & 420,483 & 70.07 \\
\hline
\end{tabular}

B. Country to region (top20)

\begin{tabular}{llrc}
\hline Origin & Destination & \multicolumn{1}{c}{ Value } & Share \\
\hline & & $(1,000$ US\$) & \multicolumn{1}{c}{$\%$} \\
China (PRC) & Developed & 138,909 & 23.15 \\
Mexico & Developed & 110,269 & 18.37 \\
Thailand & Developed & 76,411 & 12.73 \\
Malaysia & Developed & 53,006 & 8.83 \\
Korea, Republic of & Developed & 38,908 & 6.48 \\
Taiwan (estimated) & Developed & 38,484 & 6.41 \\
Indonesia & Developed & 21,507 & 3.58 \\
Turkey & Developed & 20,102 & 3.35 \\
Argentina & Developed & 12,932 & 2.15 \\
Saudi Arabia & Developed & 11,882 & 1.98 \\
Philippines & Developed & 9,010 & 1.50 \\
Spec Cats & Developed & 7,556 & 1.26 \\
Syria & Developed & 6,193 & 1.03 \\
Vietnam & Developed & 5,325 & 0.89 \\
Chile & Developed & 4,962 & 0.83 \\
Sri Lanka & Developed & 4,571 & 0.76 \\
Nigeria & Developed & 4,377 & 0.73 \\
Jamaica & Developed & 3,623 & 0.60 \\
Areas NES & Developed & 3,089 & 0.51 \\
India & Developed & 2,982 & 0.50 \\
Total & & 574,101 & 95.66 \\
\hline
\end{tabular}

C. Subregion to region (total)

\begin{tabular}{llrc}
\hline Origin & Destination & \multicolumn{1}{c}{ Value } & Share \\
\hline & & $(1,000$ US\$ $)$ & $\%$ \\
Developing & North America & 218,970 & 36.49 \\
Developing & Eastern Asia ${ }^{1}$ & 197,249 & 32.87 \\
Developing & Western Europe & 104,051 & 17.34 \\
Developing & Southeast Asia & 52,651 & 8.77 \\
Developing & Australia/NZ & 16,468 & 2.74 \\
Developing & Southern Africa & 7,198 & 1.20 \\
Developing & West Asia & 3,530 & 0.59 \\
Total & & 600,116 & 100 \\
\hline
\end{tabular}

Source: Compiled from United Nations Statistical Division, COMTRADE database (1999).

${ }^{1}$ Includes Japan, Hong Kong, and Macau. 


\section{Appendix Table 4g Cassava Exports by Developing Countries, 1994-98 Annual Average}

\begin{tabular}{|c|c|c|c|}
\hline Origin & Destination & Value & Share \\
\hline & & $(1,000$ US\$) & $\%$ \\
\hline Thailand & Netherlands, The & 179,755 & 35.40 \\
\hline Thailand & Spain & 91,672 & 18.05 \\
\hline Thailand & Belgium & 46,630 & 9.18 \\
\hline Thailand & Portugal & 35,166 & 6.93 \\
\hline Thailand & Japan & 24,194 & 4.76 \\
\hline Thailand & Germany & 24,175 & 4.76 \\
\hline Costa Rica & United States & 20,227 & 3.98 \\
\hline Indonesia & France & 11,979 & 2.36 \\
\hline Indonesia & Spain & 10,960 & 2.16 \\
\hline Thailand & Hong Kong & 8,603 & 1.69 \\
\hline Thailand & Singapore & 7,354 & 1.45 \\
\hline Thailand & United States & 6,486 & 1.28 \\
\hline Indonesia & Japan & 4,796 & 0.94 \\
\hline Indonesia & Italy & 4,499 & 0.89 \\
\hline Thailand & France & 2,785 & 0.55 \\
\hline Thailand & Australia & 2,001 & 0.39 \\
\hline Costa Rica & Netherlands, The & 1,609 & 0.32 \\
\hline Indonesia & Germany & 1,465 & 0.29 \\
\hline Indonesia & Belgium & 1,407 & 0.28 \\
\hline Philippines, The & France & 1,287 & 0.25 \\
\hline Total & & 487.050 & 95.92 \\
\hline
\end{tabular}

B. Country to region (top20)

\begin{tabular}{lrrr}
\hline Origin & Destination & \multicolumn{1}{c}{ Value } & Share \\
\hline & & $(1,000$ US\$) & \multicolumn{1}{c}{$\%$} \\
Thailand & Developed & 433,047 & 85.28 \\
Indonesia & Developed & 36,439 & 7.18 \\
Costa Rica & Developed & 23,891 & 4.70 \\
Philippines, The & Developed & 2,502 & 0.49 \\
Vietnam & Developed & 2,309 & 0.45 \\
China (PRC) & Developed & 2,277 & 0.45 \\
Ghana & Developed & 1,314 & 0.26 \\
India & Developed & 1,157 & 0.23 \\
Madagascar & Developed & 524 & 0.10 \\
Brazil & Developed & 510 & 0.10 \\
Taiwan (estimated) & Developed & 467 & 0.09 \\
Malaysia & Developed & 398 & 0.08 \\
Ecuador & Developed & 372 & 0.07 \\
Tanzania, United Republi & Developed & 291 & 0.06 \\
Argentina & Developed & 288 & 0.06 \\
Jamaica & Developed & 273 & 0.05 \\
Fiji & Developed & 271 & 0.05 \\
Dominican Republic & Developed & 193 & 0.04 \\
Benin & Developed & 176 & 0.03 \\
Tonga & Developed & 168 & 0.03 \\
Total & & & \\
\hline & & 506.866 & 99.82 \\
\hline
\end{tabular}

C. Subregion to region (total)

\begin{tabular}{llrc}
\hline Origin & Destination & \multicolumn{1}{c}{ Value } & Share \\
\hline & & $(1,000$ US\$) & \multicolumn{1}{c}{$\%$} \\
Developing & Western Europe & 427,931 & 84.27 \\
Developing & Eastern Asia $^{1}$ & 38,866 & 7.65 \\
Developing & North America & 29,051 & 5.72 \\
Developing & Southeast Asia & 8,554 & 1.68 \\
Developing & Australia/NZ & 2,594 & 0.51 \\
Developing & Southern Africa & 794 & 0.16 \\
& & & \\
Total & & 507,791 & 100 \\
\hline
\end{tabular}

Source: Compiled from United Nations Statistical Division, COMTRADE database (1999).

${ }^{1}$ Includes Japan, Hong Kong, and Macau. 


\section{Appendix Table 4h Maize Exports by Developing Countries, 1994-98 Annual Average}

\begin{tabular}{|c|c|c|c|}
\hline Origin & Destination & Value & Share \\
\hline & & $(1,000 \mathrm{US} \$)$ & $\%$ \\
\hline China (PRC) & Japan & 63,880 & 14.69 \\
\hline Argentina & Japan & 61,621 & 14.17 \\
\hline Argentina & United Kingdom & 42,400 & 9.75 \\
\hline Argentina & Spain & 40,573 & 9.33 \\
\hline Chile & United States & 36,933 & 8.50 \\
\hline Argentina & United States & 19,068 & 4.39 \\
\hline Argentina & Germany & 14,429 & 3.32 \\
\hline Argentina & S.Afr.Cus.Un & 12,185 & 2.80 \\
\hline Argentina & Portugal & 11,458 & 2.64 \\
\hline Chile & France & 9,815 & 2.26 \\
\hline Areas NES & France & 8,943 & 2.06 \\
\hline Argentina & Belgium & 8,258 & 1.90 \\
\hline Kenya & S.Afr.Cus.Un & 7,432 & 1.71 \\
\hline Zimbabwe & S.Afr.Cus.Un & 7,107 & 1.63 \\
\hline Argentina & Netherlands & 7,102 & 1.63 \\
\hline Mexico & United States & 5,733 & 1.32 \\
\hline Malaysia & Singapore & 5,511 & 1.27 \\
\hline Argentina & France & 5,271 & 1.21 \\
\hline Argentina & Italy & 3,433 & 0.79 \\
\hline Argentina & Norway & 3,384 & 0.78 \\
\hline Total & & 374.538 & 86.15 \\
\hline
\end{tabular}

\begin{tabular}{|c|c|c|c|}
\hline Origin & Destination & $\begin{array}{l}\text { Value } \\
\end{array}$ & Share \\
\hline & & $(1,000$ US\$) & $\%$ \\
\hline Argentina & Developed & 232,611 & 53.51 \\
\hline China (PRC) & Developed & 69,438 & 15.97 \\
\hline Chile & Developed & 51,928 & 11.94 \\
\hline Mexico & Developed & 9,952 & 2.29 \\
\hline Zimbabwe & Developed & 9,447 & 2.17 \\
\hline Areas NES & Developed & 9,292 & 2.14 \\
\hline Turkey & Developed & 8,016 & 1.84 \\
\hline Malaysia & Developed & 6,006 & 1.38 \\
\hline Kenya & Developed & 5,951 & 1.37 \\
\hline Brazil & Developed & 4,843 & 1.11 \\
\hline Thailand & Developed & 4,008 & 0.92 \\
\hline Indonesia & Developed & 3,659 & 0.84 \\
\hline Peru & Developed & 3,485 & 0.80 \\
\hline Vietnam & Developed & 3,390 & 0.78 \\
\hline Burma & Developed & 2,823 & 0.65 \\
\hline Venezuela & Developed & 2,157 & 0.50 \\
\hline Spec Cats & Developed & 1,575 & 0.36 \\
\hline Madagascar & Developed & 1,256 & 0.29 \\
\hline Cyprus & Developed & 779 & 0.18 \\
\hline Colombia & Developed & 521 & 0.12 \\
\hline Total & & 431.138 & 99.17 \\
\hline \multicolumn{4}{|c|}{ C. Subregion to region (total) } \\
\hline \multirow[t]{2}{*}{ Origin } & Destination & Value & Share \\
\hline & & $(1,000$ US\$) & $\%$ \\
\hline Developing & Western Europe & 178,004 & 40.94 \\
\hline Developing & Eastern Asia ${ }^{1}$ & 142,714 & 32.83 \\
\hline Developing & North America & 68,149 & 15.68 \\
\hline Developing & Southern Africa & 24,790 & 5.70 \\
\hline Developing & Southeast Asia & 15,102 & 3.47 \\
\hline Developing & West Asia & 5,498 & 1.26 \\
\hline Developing & Australia/NZ & 485 & 0.11 \\
\hline Total & & 434,742 & 100 \\
\hline
\end{tabular}

Source: Compiled from United Nations Statistical Division, COMTRADE database (1999).

${ }^{1}$ Includes Japan, Hong Kong, and Macau. 


\section{Appendix Table 4i: Bean Exports by Developing Countries, 1994-98 Annual Average}

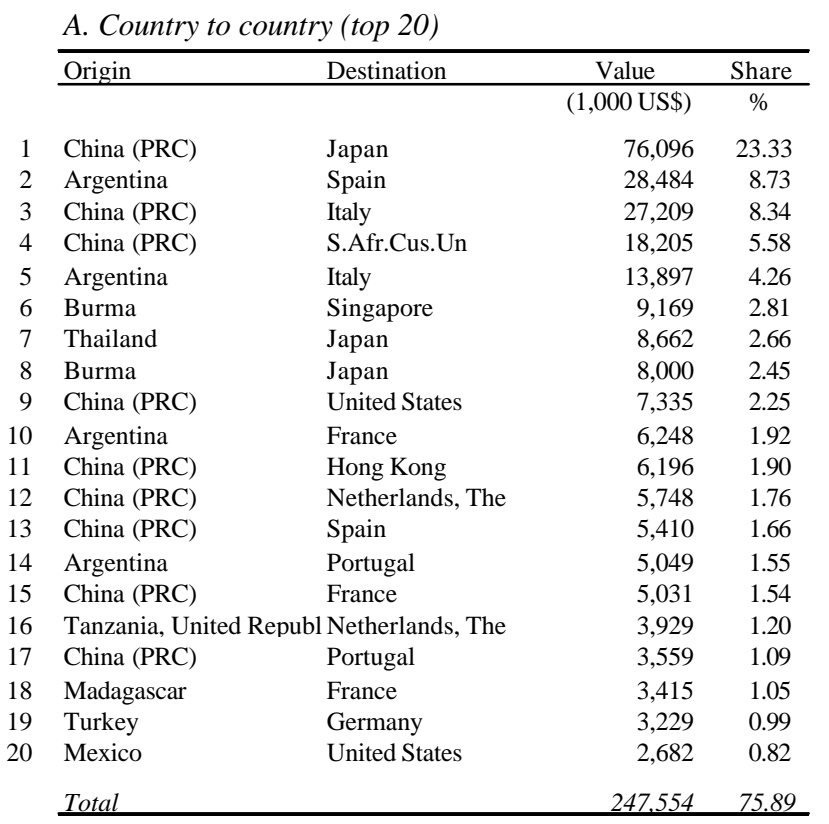

B. Country to region (top20)

\begin{tabular}{|c|c|c|c|}
\hline Origin & Destination & Value & Share \\
\hline & & $(1,000$ US\$) & $\%$ \\
\hline China (PRC) & Developed & 161,587 & 49.54 \\
\hline Argentina & Developed & 59,104 & 18.12 \\
\hline Turkey & Developed & 16,438 & 5.04 \\
\hline Burma & Developed & 19,016 & 5.83 \\
\hline Thailand & Developed & 17,752 & 5.44 \\
\hline Peru & Developed & 6,225 & 1.91 \\
\hline Ethiopia & Developed & 6,505 & 1.99 \\
\hline India & Developed & 3,978 & 1.22 \\
\hline Mexico & Developed & 4,039 & 1.24 \\
\hline Tanzania, United Republi & Developed & 4,850 & 1.49 \\
\hline Madagascar & Developed & 4,120 & 1.26 \\
\hline Chile & Developed & 4,709 & 1.44 \\
\hline Brazil & Developed & 1,733 & 0.53 \\
\hline El Salvador & Developed & 1,063 & 0.33 \\
\hline Syria & Developed & 1,985 & 0.61 \\
\hline Bolivia & Developed & 1,223 & 0.37 \\
\hline Egypt & Developed & 2,088 & 0.64 \\
\hline Vietnam & Developed & 679 & 0.21 \\
\hline Taiwan (estimated) & Developed & 692 & 0.21 \\
\hline Morocco & Developed & 736 & 0.23 \\
\hline Total & & 318,523 & 97.65 \\
\hline \multicolumn{4}{|c|}{ C. Subregion to region (total) } \\
\hline \multirow[t]{2}{*}{ Origin } & Destination & Value & Share \\
\hline & & $(1,000$ US\$) & $\%$ \\
\hline Developing & Western Europe & 167,182 & 51.25 \\
\hline Developing & Eastern Asia $^{1}$ & 105,584 & 32.37 \\
\hline Developing & North America & 20,946 & 6.42 \\
\hline Developing & Southern Africa & 16,155 & 4.95 \\
\hline Developing & Southeast Asia & 13,659 & 4.19 \\
\hline Developing & West Asia & 2,306 & 0.71 \\
\hline Developing & Australia/NZ & 347 & 0.11 \\
\hline Total & & 326,180 & 100 \\
\hline
\end{tabular}

Source: Compiled from United Nations Statistical Division, COMTRADE database (1999).

${ }^{1}$ Includes Japan, Hong Kong, and Macau. 


\section{Appendix Table 4j: Potato Exports by Developing Countries, 1994-98 Annual Average}

\begin{tabular}{rllrr}
\multicolumn{7}{c}{ A. Country to country $($ top 20) } & & \\
\cline { 2 - 4 } & Origin & Destination & Value & Share \\
\hline & & & $(1,000$ US\$) & $\%$ \\
1 & Egypt & United Kingdom & 35,919 & 15.21 \\
2 & Morocco & France & 27,844 & 11.79 \\
3 & Cyprus & United Kingdom & 27,656 & 11.71 \\
4 & Egypt & Germany & 24,119 & 10.21 \\
5 & Cyprus & Germany & 23,720 & 10.04 \\
6 & Cyprus & Belgium & 21,338 & 9.03 \\
7 & Egypt & Greece & 10,482 & 4.44 \\
8 & Morocco & Germany & 8,920 & 3.78 \\
9 & Egypt & Spain & 5,002 & 2.12 \\
10 & Cyprus & Norway & 4,722 & 2.00 \\
11 & Egypt & Italy & 4,137 & 1.75 \\
12 & Spec Cats & Netherlands, The & 4,001 & 1.69 \\
13 & Turkey & Greece & 3,623 & 1.53 \\
14 & Turkey & Italy & 2,829 & 1.20 \\
15 & Egypt & France & 2,719 & 1.15 \\
16 & Cyprus & Ireland & 2,263 & 0.96 \\
17 & Malaysia & Singapore & 2,058 & 0.87 \\
18 & Cyprus & Austria & 1,965 & 0.83 \\
19 & China (PRC) & Hong Kong & 1,537 & 0.65 \\
20 & Turkey & Spain & 1,361 & 0.58 \\
& & & 216,212 & 91.53 \\
\hline & Total & & &
\end{tabular}

B. Country to region (top20)

\begin{tabular}{lrrr}
\hline Origin & Destination & \multicolumn{1}{c}{ Value } & Share \\
\hline & & $(1,000$ US\$) & \multicolumn{1}{c}{$\%$} \\
Egypt & Developed & 84,675 & 35.85 \\
Cyprus & Developed & 83,416 & 35.31 \\
Morocco & Developed & 39,647 & 16.78 \\
Turkey & Developed & 10,562 & 4.47 \\
Spec Cats & Developed & 4,067 & 1.72 \\
China (PRC) & Developed & 3,490 & 1.48 \\
Malaysia & Developed & 3,241 & 1.37 \\
Areas NES & Developed & 1,164 & 0.49 \\
Brazil & Developed & 967 & 0.41 \\
Tunisia & Developed & 837 & 0.35 \\
Mexico & Developed & 693 & 0.29 \\
Thailand & Developed & 616 & 0.26 \\
Taiwan (estimated) & Developed & 432 & 0.18 \\
Syria & Developed & 349 & 0.15 \\
India & Developed & 220 & 0.09 \\
Jamaica & Developed & 203 & 0.09 \\
Cuba & Developed & 195 & 0.08 \\
United Arab Emirates & Developed & 177 & 0.08 \\
Korea, Republic of & Developed & 147 & 0.06 \\
Philippines, The & Developed & 126 & 0.05 \\
Total & & & \\
\hline & & 235,225 & 99.58 \\
\hline
\end{tabular}

C. Subregion to region (total)

\begin{tabular}{llrr}
\hline Origin & Destination & \multicolumn{1}{c}{ Value } & Share \\
\hline & & $(1,000$ US $\$)$ & \multicolumn{1}{c}{$\%$} \\
Developing & Western Europe & 226,338 & 95.82 \\
Developing & Eastern Asia & 4,255 & 1.80 \\
Developing & Southeast Asia & 3,519 & 1.49 \\
Developing & North America & 1,521 & 0.64 \\
Developing & West Asia & 423 & 0.18 \\
Developing & Australia/NZ & 91 & 0.04 \\
Developing & Southern Africa & 67 & 0.03 \\
Total & & 236,214 & 100 \\
\hline
\end{tabular}

Source: Compiled from United Nations Statistical Division, COMTRADE database (1999).

${ }^{1}$ Includes Japan, Hong Kong, and Macau. 


\section{Appendix Table 4k: Chickpea Exports by Developing Countries, 1994-98 Annual Average}

A. Country to country (top 20)

\begin{tabular}{lllrr}
\cline { 2 - 4 } & Origin & Destination & Value & Share \\
\cline { 2 - 5 } 1 & Mexico & Spain & 34,000 US $\$$ & $\%$ \\
2 & Mexico & United States & 7,352 & 37.33 \\
3 & Mexico & Italy & 6,260 & 7.72 \\
4 & Turkey & Italy & 5,980 & 6.50 \\
5 & Turkey & France & 5,680 & 6.17 \\
6 & Turkey & Spain & 5,424 & 5.89 \\
7 & Turkey & Israel & 3,143 & 3.42 \\
8 & Turkey & Greece & 3,081 & 3.35 \\
9 & Turkey & Portugal & 2,781 & 3.02 \\
0 & Mexico & Portugal & 2,744 & 2.98 \\
1 & Mexico & France & 2,031 & 2.21 \\
2 & Turkey & United Kingdom & 2,018 & 2.19 \\
3 & Mexico & Greece & 1,770 & 1.92 \\
14 & Turkey & Germany & 1,509 & 1.64 \\
5 & India & United Kingdom & 1,091 & 1.19 \\
6 & Turkey & United States & 703 & 0.76 \\
7 & Turkey & Netherlands, The & 559 & 0.61 \\
8 & Mexico & Canada & 531 & 0.58 \\
9 & Turkey & Canada & 519 & 0.56 \\
20 & India & United States & 414 & 0.45 \\
& & & 87,690 & 95.29 \\
\hline
\end{tabular}

B. Country to region (top20)

\begin{tabular}{|c|c|c|c|}
\hline Origin & Destination & Value & Share \\
\hline & & $(1,000$ US $\$)$ & $\%$ \\
\hline Mexico & Developed & 55,592 & 60.41 \\
\hline Turkey & Developed & 32,834 & 35.68 \\
\hline India & Developed & 1,802 & 1.96 \\
\hline Lebanon & Developed & 426 & 0.46 \\
\hline Morocco & Developed & 302 & 0.33 \\
\hline Iran & Developed & 157 & 0.17 \\
\hline Chile & Developed & 147 & 0.16 \\
\hline Syria & Developed & 143 & 0.16 \\
\hline Malawi & Developed & 94 & 0.10 \\
\hline United Arab Emirates & Developed & 70 & 0.08 \\
\hline China (PRC) & Developed & 63 & 0.07 \\
\hline Burma & Developed & 62 & 0.07 \\
\hline Thailand & Developed & 52 & 0.06 \\
\hline Malaysia & Developed & 45 & 0.05 \\
\hline Egypt & Developed & 38 & 0.04 \\
\hline Peru & Developed & 21 & 0.02 \\
\hline Argentina & Developed & 17 & 0.02 \\
\hline Tanzania, United Republi & Developed & 17 & 0.02 \\
\hline Cyprus & Developed & 16 & 0.02 \\
\hline Ecuador & Developed & 14 & 0.01 \\
\hline Total & & 91,911 & 99.88 \\
\hline \multicolumn{4}{|c|}{ C. Subregion to region (total) } \\
\hline \multirow[t]{2}{*}{ Origin } & Destination & Value & Share \\
\hline & & $(1,000$ US\$) & $\%$ \\
\hline Developing & Western Europe & 78,052 & 84.82 \\
\hline Developing & North America & 9,507 & 10.33 \\
\hline Developing & West Asia & 3,445 & 3.74 \\
\hline Developing & Eastern Asia ${ }^{1}$ & 389 & 0.42 \\
\hline Developing & Southeast Asia & 354 & 0.39 \\
\hline Developing & Southern Africa & 151 & 0.16 \\
\hline Developing & Australia/NZ & 122 & 0.13 \\
\hline Total & & 92,021 & 100 \\
\hline
\end{tabular}

Source: Compiled from United Nations Statistical Division, COMTRADE database (1999).

${ }^{1}$ Includes Japan, Hong Kong, and Macau. 


\section{Appendix Table 4l Sorghum Exports by Developing Countries, 1994-98 Annual Average}

\begin{tabular}{|c|c|c|c|}
\hline Origin & Destination & Value & Share \\
\hline & & $(1,000$ US\$) & $\%$ \\
\hline Argentina & Japan & 52,720 & 64.04 \\
\hline China (Ppls. Rep. of) & Japan & 7,706 & 9.36 \\
\hline Sudan & Japan & 7,482 & 9.09 \\
\hline Sudan & Italy & 6,195 & 7.53 \\
\hline Argentina & Spain & 1,705 & 2.07 \\
\hline Sudan & Belgium & 1,489 & 1.81 \\
\hline Sudan & Norway & 691 & 0.84 \\
\hline India & Japan & 654 & 0.79 \\
\hline Argentina & Norway & 486 & 0.59 \\
\hline Sudan & Germany & 427 & 0.52 \\
\hline China (Ppls. Rep. of) & Belgium & 326 & 0.40 \\
\hline China (Ppls. Rep. of) & Netherlands, The & 317 & 0.39 \\
\hline Argentina & United States & 301 & 0.37 \\
\hline Cyprus & Italy & 171 & 0.21 \\
\hline Thailand & Japan & 166 & 0.20 \\
\hline Sudan & Netherlands, The & 138 & 0.17 \\
\hline Zimbabwe & S.Afr.Cus.Un & 130 & 0.16 \\
\hline China (Ppls. Rep. of) & Germany & 101 & 0.12 \\
\hline Areas NES & France & 98 & 0.12 \\
\hline Greenland & Japan & 98 & 0.12 \\
\hline Total & & 81,401 & 98.88 \\
\hline
\end{tabular}

B. Country to region (top20)

\begin{tabular}{|c|c|c|c|}
\hline Origin & Destination & Value & Share \\
\hline & & $(1,000$ US\$) & $\%$ \\
\hline Argentina & Developed & 55,287 & 67.16 \\
\hline Sudan & Developed & 16,485 & 20.03 \\
\hline China (PRC) & Developed & 8,548 & 10.38 \\
\hline India & Developed & 826 & 1.00 \\
\hline Egypt & Developed & 191 & 0.23 \\
\hline Cyprus & Developed & 171 & 0.21 \\
\hline Thailand & Developed & 166 & 0.20 \\
\hline Zimbabwe & Developed & 111 & 0.13 \\
\hline Areas NES & Developed & 98 & 0.12 \\
\hline Greenland & Developed & 98 & 0.12 \\
\hline Korea, Republic of & Developed & 88 & 0.11 \\
\hline Mexico & Developed & 83 & 0.10 \\
\hline Panama & Developed & 64 & 0.08 \\
\hline Chile & Developed & 42 & 0.05 \\
\hline Zambia & Developed & 17 & 0.02 \\
\hline Falkland Islands & Developed & 17 & 0.02 \\
\hline Taiwan (estimated) & Developed & 10 & 0.01 \\
\hline Tunisia & Developed & 7 & 0.01 \\
\hline Brazil & Developed & 6 & 0.01 \\
\hline United Arab Emirates & Developed & 2 & 0.00 \\
\hline Total & & 82,315 & 100.00 \\
\hline
\end{tabular}

C. Subregion to region (total)

\begin{tabular}{llrr}
\hline Origin & Destination & \multicolumn{1}{c}{ Value } & Share \\
\hline & & $(1,000$ US\$) & \multicolumn{1}{c}{} \\
& & 68,978 & 83.79 \\
Developing & Eastern Asia ${ }^{1}$ & 12,719 & 15.45 \\
Developing & Western Europe & 400 & 0.49 \\
Developing & North America & 137 & 0.17 \\
Developing & Southern Africa & 67 & 0.08 \\
Developing & West Asia & 19 & 0.02 \\
Developing & Southeast Asia & & \\
& & 82,319 & 100 \\
\hline
\end{tabular}

Source: Compiled from United Nations Statistical Division, COMTRADE database (1999).

${ }^{1}$ Includes Japan, Hong Kong, and Macau. 


\section{Appendix Table 4m: Lentil Exports by Developing Countries, 1994-98 Annual Average}

\begin{tabular}{|c|c|c|c|}
\hline Origin & Destination & Value & Share \\
\hline & & $(1,000$ US\$) & $\%$ \\
\hline China (PRC) & France & 4,076 & 18.67 \\
\hline Turkey & Germany & 3,129 & 14.34 \\
\hline Turkey & United Kingdom & 1,778 & 8.15 \\
\hline Turkey & Italy & 1,737 & 7.96 \\
\hline Turkey & Israel & 1,164 & 5.33 \\
\hline India & United States & 1,109 & 5.08 \\
\hline Turkey & Spain & 1,105 & 5.06 \\
\hline India & Canada & 661 & 3.03 \\
\hline Turkey & France & 645 & 2.96 \\
\hline Turkey & Netherlands, The & 605 & 2.77 \\
\hline Turkey & United States & 523 & 2.40 \\
\hline China (PRC) & Netherlands, The & 505 & 2.31 \\
\hline Turkey & Canada & 478 & 2.19 \\
\hline China (PRC) & Belgium & 378 & 1.73 \\
\hline China (PRC) & Hong Kong & 333 & 1.53 \\
\hline Turkey & S.Afr.Cus.Un & 284 & 1.30 \\
\hline China (PRC) & S.Afr.Cus.Un & 255 & 1.17 \\
\hline India & Australia & 230 & 1.05 \\
\hline Turkey & Belgium & 197 & 0.90 \\
\hline China (PRC) & Spain & 180 & 0.82 \\
\hline Total & & 19.372 & 88.76 \\
\hline
\end{tabular}

B. Country to region (top20)

\begin{tabular}{llrc}
\hline Origin & Destination & Value & Share \\
\hline & & $(1,000$ US $\$)$ & $\%$ \\
Turkey & Developed & 12,306 & 56.38 \\
China (PRC) & Developed & 5,999 & 27.48 \\
India & Developed & 2,417 & 11.07 \\
Afrrica Other NS & Developed & 160 & 0.73 \\
Argentina & Developed & 153 & 0.70 \\
Thailand & Developed & 140 & 0.64 \\
Madagascar & Developed & 113 & 0.52 \\
Lebanon & Developed & 77 & 0.35 \\
Malawi & Developed & 55 & 0.25 \\
Syria & Developed & 52 & 0.24 \\
Vietnam & Developed & 33 & 0.15 \\
Sri Lanka & Developed & 32 & 0.15 \\
Mexico & Developed & 31 & 0.14 \\
Tokelau & Developed & 30 & 0.14 \\
United Arab Emirates & Developed & 27 & 0.13 \\
Ethiopia & Developed & 22 & 0.10 \\
Panama & Developed & 19 & 0.09 \\
Nepal & Developed & 18 & 0.08 \\
Egypt & Developed & 14 & 0.06 \\
Venezuela & Developed & 13 & 0.06 \\
Total & & & \\
\hline
\end{tabular}

C. Subregion to region (total)

\begin{tabular}{llrc}
\hline Origin & Destination & \multicolumn{1}{c}{ Value } & Share \\
\hline & & $(1,000$ US\$) & \multicolumn{1}{c}{$\%$} \\
Developing & Western Europe & 15,999 & 73.30 \\
Developing & North America & 2,976 & 13.64 \\
Developing & West Asia & 1,266 & 5.80 \\
Developing & Southern Africa & 543 & 2.49 \\
Developing & Australia/NZ & 385 & 1.76 \\
Developing & Eastern Asia & \\
Developing & Southeast Asia & 379 & 1.74 \\
Total & & 277 & 1.27 \\
\hline
\end{tabular}

Source: Compiled from United Nations Statistical Division, COMTRADE database (1999).

${ }^{1}$ Includes Japan, Hong Kong, and Macau. 


\section{Appendix Table 4n: Millet Exports by Developing Countries, 1994-98 Annual Average}

\begin{tabular}{|c|c|c|c|}
\hline Origin & Destination & Value & Share \\
\hline & & $(1,000$ US\$) & $\%$ \\
\hline China (PRC) & Japan & 3,015 & 18.18 \\
\hline Argentina & Netherlands, The & 2,544 & 15.34 \\
\hline Argentina & Belgium & 2,063 & 12.44 \\
\hline Argentina & Germany & 1,848 & 11.14 \\
\hline China (PRC) & Germany & 1,373 & 8.28 \\
\hline China (PRC) & United Kingdom & 1,246 & 7.51 \\
\hline China (PRC) & Netherlands, The & 1,103 & 6.65 \\
\hline China (PRC) & Italy & 328 & 1.98 \\
\hline China (PRC) & Hong Kong & 312 & 1.88 \\
\hline Argentina & Switzerland & 242 & 1.46 \\
\hline China (PRC) & Belgium & 226 & 1.36 \\
\hline Argentina & United States & 224 & 1.35 \\
\hline Argentina & France & 212 & 1.28 \\
\hline China (PRC) & Denmark & 212 & 1.28 \\
\hline Sudan & Netherlands, The & 201 & 1.21 \\
\hline India & United Kingdom & 166 & 1.00 \\
\hline Vietnam & Japan & 124 & 0.75 \\
\hline Argentina & Denmark & 111 & 0.67 \\
\hline Argentina & Spain & 110 & 0.66 \\
\hline China (PRC) & France & 107 & 0.64 \\
\hline Total & & 15.768 & 95.05 \\
\hline
\end{tabular}

B. Country to region (top20)

\begin{tabular}{llrr}
\hline Origin & Destination & \multicolumn{1}{c}{ Value } & Share \\
\hline & & $(1,000$ US\$) & \multicolumn{1}{c}{$\%$} \\
China (PRC) & Developed & 8,217 & 49.53 \\
Argentina & Developed & 7,508 & 45.26 \\
India & Developed & 311 & 1.88 \\
Sudan & Developed & 202 & 1.22 \\
Vietnam & Developed & 124 & 0.75 \\
Kenya & Developed & 64 & 0.39 \\
Uruguay & Developed & 24 & 0.15 \\
Korea, Republic of & Developed & 20 & 0.12 \\
Egypt & Developed & 16 & 0.10 \\
Burma & Developed & 15 & 0.09 \\
Zimbabwe & Developed & 14 & 0.09 \\
Philippines & Developed & 12 & 0.07 \\
Free Zones & Developed & 8 & 0.05 \\
Malaysia & Developed & 8 & 0.05 \\
Ethiopia & Developed & 8 & 0.05 \\
Taiwan (estimated) & Developed & 6 & 0.04 \\
Bolivia & Developed & 5 & 0.03 \\
Senegal & Developed & 4 & 0.03 \\
Brazil & Developed & 4 & 0.02 \\
Areas NES & Developed & 4 & 0.02 \\
Total & & 16.574 & 99.90 \\
\hline & & &
\end{tabular}

C. Subregion to region (total)

\begin{tabular}{llrc}
\hline Origin & Destination & \multicolumn{1}{c}{ Value } & Share \\
\hline & & $(1,000$ US\$) & $\%$ \\
Developing & Western Europe & 12,524 & 75.49 \\
Developing & Eastern Asia $^{1}$ & 3,535 & 21.31 \\
Developing & North America & 341 & 2.06 \\
Developing & Southern Africa & 84 & 0.50 \\
Developing & Southeast Asia & 67 & 0.41 \\
Developing & West Asia & 28 & 0.17 \\
Developing & Australia/NZ & 9 & 0.06 \\
Total & & 16,590 & 100 \\
\hline
\end{tabular}

Source: Compiled from United Nations Statistical Division, COMTRADE database (1999).

${ }^{1}$ Includes Japan, Hong Kong, and Macau. 


\section{Appendix Table 4o: Barley Exports by Developing Countries, 1994-98 Annual Average}

\begin{tabular}{|c|c|c|c|c|c|c|c|}
\hline \multicolumn{4}{|c|}{ A. Country to country (top 20) } & \multicolumn{4}{|c|}{ B. Country to region (top20) } \\
\hline Origin & Destination & Value & Share & Origin & Destination & Value & Share \\
\hline & & $(1,000$ US\$) & $\%$ & & & $(1,000$ US\$) & $\%$ \\
\hline Turkey & Israel & 1,458 & 31.58 & Turkey & Developed & 1,581 & 34.23 \\
\hline Cyprus & Israel & 1,041 & 22.53 & Cyprus & Developed & 1,041 & 22.53 \\
\hline Uruguay & Germany & 599 & 12.98 & Uruguay & Developed & 994 & 21.53 \\
\hline Uruguay & Malta and Gozo & 388 & 8.40 & Argentina & Developed & 483 & 10.45 \\
\hline Argentina & Germany & 243 & 5.25 & Areas NES & Developed & 197 & 4.27 \\
\hline Argentina & Israel & 236 & 5.11 & China (PRC) & Developed & 91 & 1.97 \\
\hline Areas NES & France & 197 & 4.27 & Thailand & Developed & 84 & 1.83 \\
\hline Turkey & Malta and Gozo & 113 & 2.45 & Korea, Republic of & Developed & 49 & 1.06 \\
\hline Korea, Republic of & United States & 47 & 1.02 & Cocos (Keeling) Isles & Developed & 39 & 0.84 \\
\hline China (PRC) & United States & 44 & 0.95 & Chile & Developed & 15 & 0.33 \\
\hline Thailand & United States & 42 & 0.91 & Spec Cats & Developed & 13 & 0.29 \\
\hline Cocos (Keeling) Isles & France & 39 & 0.84 & El Salvador & Developed & 13 & 0.28 \\
\hline Thailand & Hong Kong & 34 & 0.73 & Malaysia & Developed & 13 & 0.27 \\
\hline China (PRC) & Hong Kong & 17 & 0.36 & Peru & Developed & 2 & 0.04 \\
\hline Spec Cats & Canada & 13 & 0.29 & Taiwan (estimated) & Developed & 1 & 0.03 \\
\hline El Salvador & United States & 13 & 0.28 & Egypt & Developed & 1 & 0.02 \\
\hline China (PRC) & Australia & 11 & 0.23 & Ecuador & Developed & 1 & 0.01 \\
\hline China (PRC) & Singapore & 10 & 0.23 & Bunkers & Developed & 0 & 0.01 \\
\hline Turkey & Ireland & 9 & 0.20 & Kenya & Developed & 0 & 0.00 \\
\hline China (PRC) & Canada & 9 & 0.19 & Brazil & Developed & 0 & 0.00 \\
\hline \multirow[t]{11}{*}{$\underline{\text { Total }}$} & & 4.563 & 98.81 & $\underline{\text { Total }}$ & & 4.618 & 99.99 \\
\hline & & & & \multicolumn{4}{|c|}{ C. Subregion to region (total) } \\
\hline & & & & Origin & Destination & Value & Share \\
\hline & & & & & & $(1,000$ US\$) & $\%$ \\
\hline & & & & Developing & West Asia & 2,735 & 59.22 \\
\hline & & & & Developing & Western Europe & 1,608 & 34.83 \\
\hline & & & & Developing & North America & 187 & 4.04 \\
\hline & & & & Developing & Eastern Asia $^{1}$ & 50 & 1.09 \\
\hline & & & & Developing & Australia/NZ & 20 & 0.43 \\
\hline & & & & Developing & Southeast Asia & 18 & 0.39 \\
\hline & & & & Total & & 4,618 & 100 \\
\hline
\end{tabular}

Source: Compiled from United Nations Statistical Division, COMTRADE database (1999).

${ }^{1}$ Includes Japan, Hong Kong, and Macau. 


\section{List of EPTD Discussion Papers}

01 Sustainable Agricultural Development Strategies in Fragile Lands, by Sara J. Scherr and Peter B.R. Hazell, June 1994.

02 Confronting the Environmental Consequences of the Green Revolution in Asia, by Prabhu L. Pingali and Mark W. Rosegrant, August 1994.

03 Infrastructure and Technology Constraints to Agricultural Development in the Humid and Subhumid Tropics of Africa, by Dunstan S.C. Spencer, August 1994.

04 Water Markets in Pakistan: Participation and Productivity, by Ruth Meinzen-Dick and Martha Sullins, September 1994.

05 The Impact of Technical Change in Agriculture on Human Fertility: District-level Evidence from India, by Stephen A. Vosti, Julie Witcover, and Michael Lipton, October 1994.

06 Reforming Water Allocation Policy Through Markets in Tradable Water Rights: Lessons from Chile, Mexico, and California, by Mark W. Rosegrant and Renato Gazmuri S., October 1994.

07 Total Factor Productivity and Sources of Long-Term Growth in Indian Agriculture, by Mark W. Rosegrant and Robert E. Evenson, April 1995.

08 Farm-Nonfarm Growth Linkages in Zambia, by Peter B.R. Hazell and Behjat Hojjati, April 1995.

09 Livestock and Deforestation in Central America in the 1980s and 1990s: A Policy Perspective, by David Kaimowitz (Interamerican Institute for Cooperation on Agriculture), June 1995.

10 Effects of the Structural Adjustment Program on Agricultural Production and Resource Use in Egypt, by Peter B. R. Hazell, Nicostrato Perez, Gamal Siam and Ibrahim Soliman, August 1995.

11 Local Organizations for Natural Resource Management: Lessons from Theoretical and Empirical Literature, by Lise Nordvig Rasmussen and Ruth Meinzen-Dick, August 1995. 
12 Quality-Equivalent and Cost-Adjusted Measurement of International Competitiveness in Japanese Rice Markets, by Shoichi Ito, Mark W. Rosegrant, and Mercedita C. AgcaoiliSombilla, August, 1995.

13 Role of Inputs, Institutions, and Technical Innovations in Stimulating Growth in Chinese Agriculture, by Shenggen Fan and Philip G. Pardey, September 1995.

14 Investments in African Agricultural Research, by Philip G. Pardey, Johannes Roseboom, and Nienke Beintema, October 1995.

15 Role of Terms of Trade in Indian Agricultural Growth: A National and State Level Analysis, by Peter B. R. Hazell, V. N. Misra and Behjat Hojjati, December 1995.

16 Policies and Markets for Non-Timber Tree Products, by Peter A. Dewees and Sara J. Scherr, March 1996.

17 Determinants of Farmers' Indigenous Soil and Water Conservation Investments in India's Semi-Arid Tropics, by John Pender and John Kerr, August 1996.

18 Summary of a Productive Partnership: The Benefits from U.S. Participation in the CGIAR, by Philip G. Pardey, Julian M. Alston, Jason E. Christian and Shenggen Fan, October 1996.

19 Crop Genetic Resource Policy: Towards a Research Agenda, by Brian D. Wright, October 1996.

20 Sustainable Development of Rainfed Agriculture in India, by John M. Kerr, November 1996.

21 Impact of Market and Population Pressure on Production, Incomes and Natural Resources in the Dryland Savannas of West Africa: Bioeconomic Modeling at the Village Level, by Bruno Barbier, November 1996.

22 Why do Projections on China's Future Food Supply and Demand Differ? by Shenggen Fan and Mercedita Agcaoili-Sombilla, March 1997.

23 Agroecological Aspects of Evaluating Agricultural R\&D, by Stanley Wood and Philip G. Pardey, March 1997. 
24 Population Pressure, Land Tenure, and Tree Resource Management in Uganda, by Frank Place and Keijiro Otsuka, March 1997.

25 Should India Invest More in Less-favored Areas? by Shenggen Fan and Peter Hazell, April 1997.

26 Population Pressure and the Microeconomy of Land Management in Hills and Mountains of Developing Countries, by Scott R. Templeton and Sara J. Scherr, April 1997.

27 Population Land Tenure, and Natural Resource Management: The Case of Customary Land Area in Malawi, by Frank Place and Keijiro Otsuka, April 1997.

28 Water Resources Development in Africa: A Review and Synthesis of Issues, Potentials, and Strategies for the Future, by Mark W. Rosegrant and Nicostrato D. Perez, September 1997.

29 Financing Agricultural R\&D in Rich Countries: What's Happening and Why, by Julian M. Alston, Philip G. Pardey, and Vincent H. Smith, September 1997.

30 How Fast Have China's Agricultural Production and Productivity Really Been Growing? by Shenggen Fan, September 1997.

31 Does Land Tenure Insecurity Discourage Tree Planting? Evolution of Customary Land Tenure and Agroforestry Management in Sumatra, by Keijiro Otsuka, S. Suyanto, and Thomas P. Tomich, December 1997.

32 Natural Resource Management in the Hillsides of Honduras: Bioeconomic Modeling at the Micro-Watershed Level, by Bruno Barbier and Gilles Bergeron, January 1998.

33 Government Spending, Growth and Poverty: An Analysis of Interlinkages in Rural India, by Shenggen Fan, Peter Hazell, and Sukhadeo Thorat, March 1998, Revised December 1998.

34 Coalitions and the Organization of Multiple-Stakeholder Action: A Case Study of Agricultural Research and Extension in Rajasthan, India, by Ruth Alsop, April 1998.

35 Dynamics in the Creation and Depreciation of Knowledge and the Returns to Research, by Julian Alston, Barbara Craig, and Philip Pardey, July 1998. 
36 Educating Agricultural Researchers: A Review of the Role of African Universities, by Nienke M. Beintema, Philip G. Pardey, and Johannes Roseboom, August 1998.

37 The Changing Organizational Basis of African Agricultural Research, by Johannes Roseboom, Philip G. Pardey, and Nienke M. Beintema, November 1998.

38 Research Returns Redux: A Meta-Analysis of the Returns to Agricultural R\&D, by Julian M. Alston, Michele C. Marra, Philip G. Pardey, and T.J. Wyatt, November 1998.

39 Technological Change, Technical and Allocative Efficiency in Chinese Agriculture: The Case of Rice Production in Jiangsu, by Shenggen Fan, January 1999.

40 The Substance of Interaction: Design and Policy Implications of NGO-Government Projects in India, by Ruth Alsop with Ved Arya, January 1999.

41 Strategies for Sustainable Agricultural Development in the East African Highlands, by John Pender, Frank Place, and Simeon Ehui, April 1999.

42 Cost Aspects of African Agricultural Research, by Philip G. Pardey, Johannes Roseboom, Nienke M. Beintema, and Connie Chan-Kang, April 1999.

43 Are Returns to Public Investment Lower in Less-favored Rural Areas? An Empirical Analysis of India, by Shenggen Fan and Peter Hazell, May 1999.

44 Spatial Aspects of the Design and Targeting of Agricultural Development Strategies, by Stanley Wood, Kate Sebastian, Freddy Nachtergaele, Daniel Nielsen, and Aiguo Dai, May 1999.

45 Pathways of Development in the Hillsides of Honduras: Causes and Implications for Agricultural Production, Poverty, and Sustainable Resource Use, by John Pender, Sara J. Scherr, and Guadalupe Durón, May 1999.

46 Determinants of Land Use Change: Evidence from a Community Study in Honduras, by Gilles Bergeron and John Pender, July 1999.

47 Impact on Food Security and Rural Development of Reallocating Water from Agriculture, by Mark W. Rosegrant and Claudia Ringler, August 1999. 
48 Rural Population Growth, Agricultural Change and Natural Resource Management in Developing Countries: A Review of Hypotheses and Some Evidence from Honduras, by John Pender, August 1999.

49 Organizational Development and Natural Resource Management: Evidence from Central Honduras, by John Pender and Sara J. Scherr, November 1999.

50 Estimating Crop-Specific Production Technologies in Chinese Agriculture: A Generalized Maximum Entropy Approach, by Xiaobo Zhang and Shenggen Fan, September 1999.

51 Dynamic Implications of Patenting for Crop Genetic Resources, by Bonwoo Koo and Brian D. Wright, October 1999.

52 Costing the Ex Situ Conservation of Genetic Resources: Maize and Wheat at CIMMYT, by Philip G. Pardey, Bonwoo Koo, Brian D. Wright, M.Eric van Dusen, Bent Skovmand, and Suketoshi Taba, October 1999.

53 Past and Future Sources of Growth for China, by Shenggen Fan, Xiaobo Zhang, and Sherman Robinson, October 1999.

54 The Timing of Evaluation of Genebank Accessions and the Effects of Biotechnology, by Bonwoo Koo and Brian D. Wright, October 1999.

55 New Approaches to Crop Yield Insurance in Developing Countries, by Jerry Skees, Peter Hazell, and Mario Miranda, November 1999.

56 Impact of Agricultural Research on Poverty Alleviation: Conceptual Framework with Illustrations from the Literature, by John Kerr and Shashi Kolavalli, December 1999.

57 Could Futures Markets Help Growers Better Manage Coffee Price Risks in Costa Rica? by Peter Hazell, January 2000.

58 Industrialization, Urbanization, and Land Use in China, by Xiaobo Zhang, Tim Mount and Richard Boisvert, January 2000.

59 Water Rights and Multiple Water Uses: Framework and Application to Kirindi Oya Irrigation System, Sri Lanka, by Ruth Meinzen-Dick and Margaretha Bakker, March 2000. 
60 Community Natural Resource Management: The Case of Woodlots in Northern Ethiopia, by Berhanu Gebremedhin, John Pender and Girmay Tesfaye, April 2000.

61 What Affects Organization and Collective Action for Managing Resources? Evidence from Canal Irrigation Systems in India, by Ruth Meinzen-Dick, K.V. Raju, and Ashok Gulati, June 2000.

62 The Effects of the U.S. Plant Variety Protection Act on Wheat Genetic Improvement, by Julian M. Alston and Raymond J. Venner, May 2000.

63 Integrated Economic-Hydrologic Water Modeling at the Basin Scale: The Maipo River Basin, by M.W. Rosegrant, C. Ringler, D.C. McKinney, X. Cai, A. Keller, and G. Donoso, May 2000.

64 Irrigation and Water Resources in Latin America and the Caribbean: Challenges and Strategies, by Claudia Ringler, Mark W. Rosegrant, and Michael S. Paisner, June 2000.

65 The Role of Trees for Sustainable Management of Less-Favored Lands: The Case of Eucalyptus in Ethiopia, by Pamela Jagger \& John Pender, June 2000.

66 Growth and Poverty in Rural China: The Role of Public Investments, by Shenggen Fan, Linxiu Zhang, and Xiaobo Zhang, June 2000.

67 Small-Scale Farms in the Western Brazilian Amazon: Can They Benefit from Carbon Trade? by Chantal Carpentier, Steve Vosti and Julie Witcover, September 2000.

68 An Evaluation of Dryland Watershed Development Projects in India, by John Kerr, Ganesh Pangare, Vasudha Lokur Pangare, and P.J. George, October 2000.

69 Consumption Effects of Genetic Modification: What If Consumers Are Right? by Konstantinos Giannakas and Murray Fulton, December 2000.

70 South-North Trade, Intellectual Property Jurisdictions, and Freedom to Operate in Agricultural Research on Staple Crops, by Eran Binenbaum, Carol Nottenburg, Philip G. Pardey, Brian D. Wright, and Patricia Zambrano, December 2000. 